مجلة جامعة الهلك عبدالعزيز: الآداب والعلوم الانسانية، م29ع1 ص ص: 75- 113 (2021م)

DOI:10.4197/Art.29-1.4

\title{
الضغوط النفسية وعلاقتها بالأفكار اللاعقلانية لدى العاملين في مهنة التمريض في مستشفى ومر اكز الرعاية الأولية بمحافظة القويعية
}

\author{
د. عبدالله بن صالح القحطاني

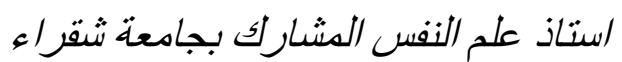

Dr.aalgahtani@su.edu.sa

\begin{abstract}
مستخلص. هدفت الدراسة إلى التعرف على الضغوط النفسية وعلاقتها بالأفكار اللاعقلانية لاى العاملين في مهنة

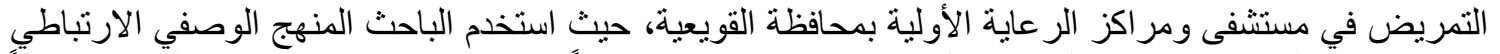

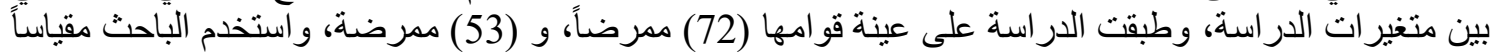

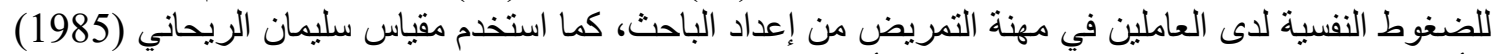

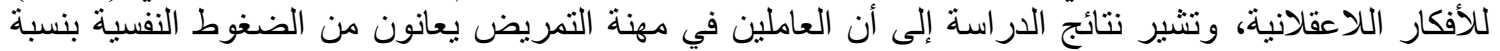

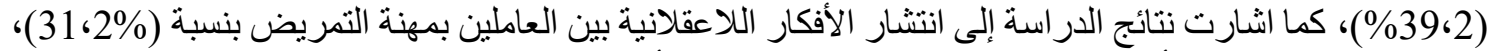

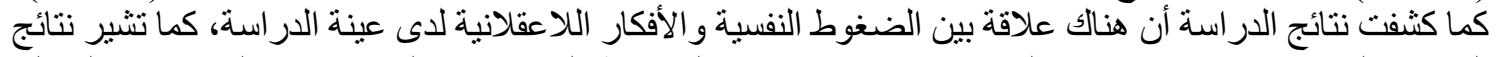

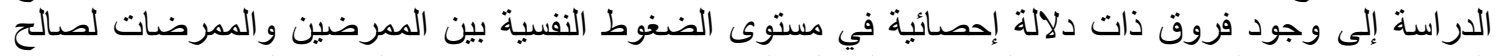

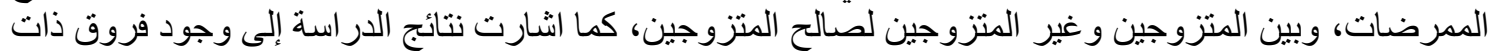

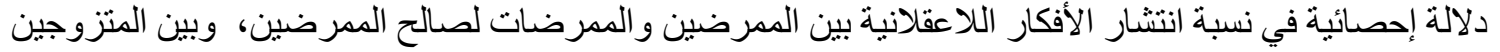

و الغير متزوجين لصالح الغير متزوجين.
\end{abstract}

الفرد هذه الأفكار اللاعقلانبة يضطرب سلوكه فيصبح

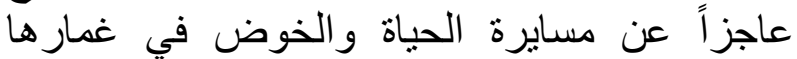
ويكون عرضة للضغوط وايرة والاضطراة وابات ل النفسية،

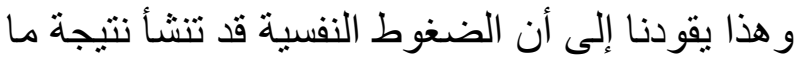

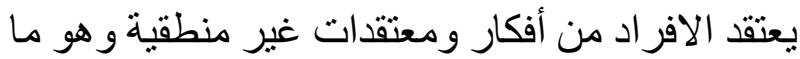
Palmer, \& أكدنه دراسات سابقة مثل دراس استخات (Dryden, 2002)

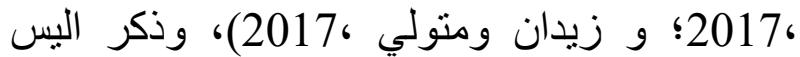
(Ellis,1990)

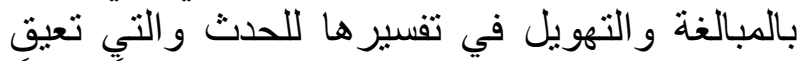

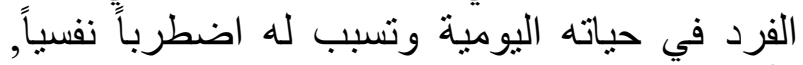
وأنشار بالمر و درائه اليدن أن الأفكار الخاطئة وغير العقلانية و التي تتصف بـت بعدم

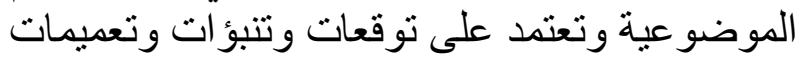

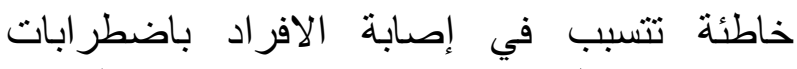

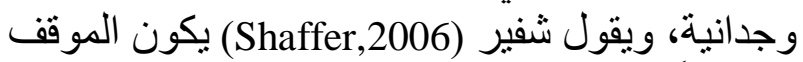
ضاغطاً إذا قامت العمليات العقلانية التفسيرية لاى لئى

\section{المقدمة}

ظهر في السنوات الأخيرة التوجه للتركيز على أهمية

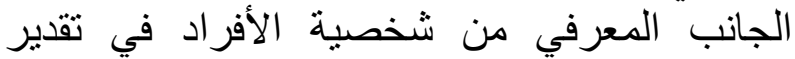
انفعالاتهم وفي تكيفهم النفسي والاجتماعي، بحئ بحيث

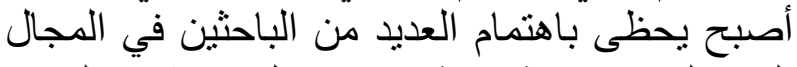

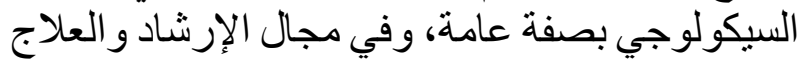

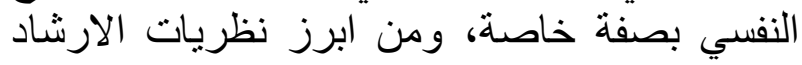

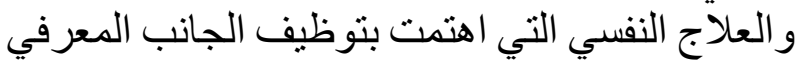
وعملت على تفسير الاضطرابات الانفعالية في الني علاقتها بالتفكير اللاعقلاني نظرية اليس (Ellis) و التي تعرف بنظرية العلاج العقلاني الانفعالي، وتسعى هذئ التئي

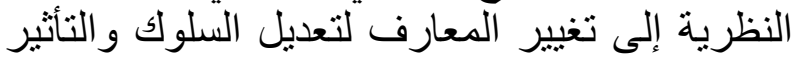

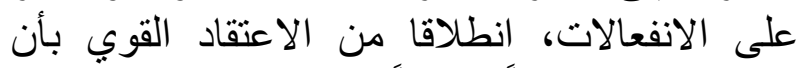

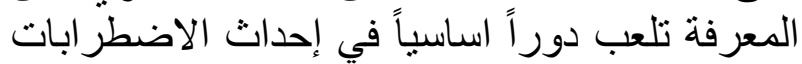
النفسية و علاجها (Scott,2004, P120). وقد حدد اليس Ellis إحدى عشر فكرة غير عقلانية وهي شائعة في المجتمعات المختلفة، وعندما يتبنى عير عنى 
جليلة لكافة افر اد المجتمع ، وهم كباقي الأفراد في

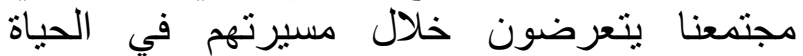

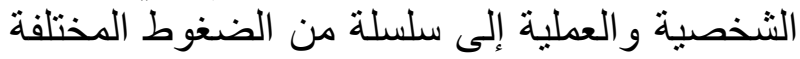

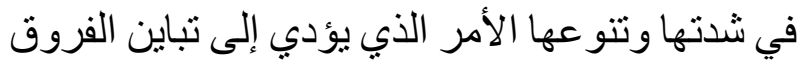

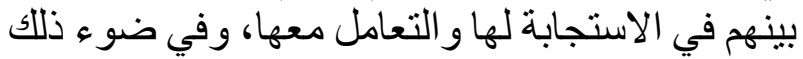

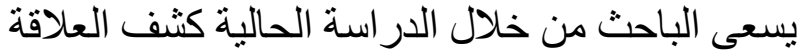

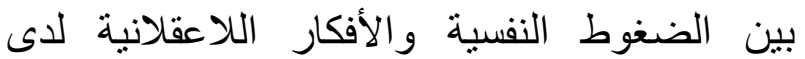
العاملين في مهنة التمريض في مستشفى ومر اكز الر عاية الأولية بمحافظة القويعية.

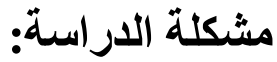
تعتبر الضغوط النفسية وما تسببه من آثار سلبية

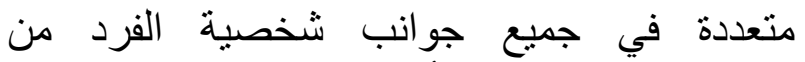

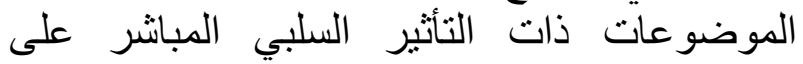

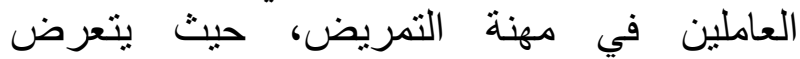

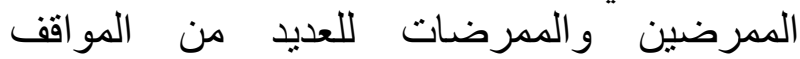

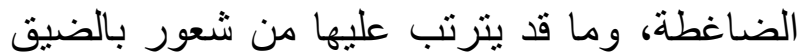

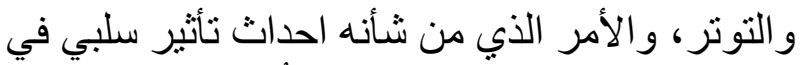

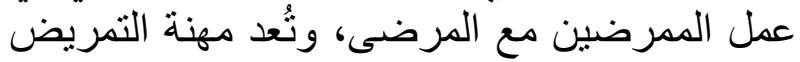

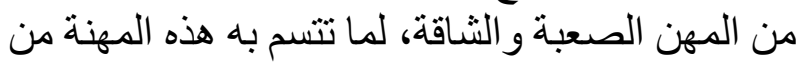

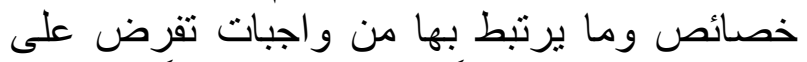

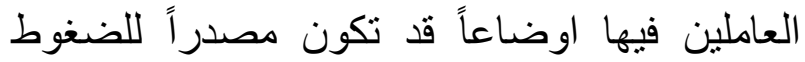
النفسية (Marrina, 2010). وكثفت دراسات دوقان (Dugan, 2016؛ و و باتريك Patrick,2013) و ويو (Wu,2012) أن العاملين في دوني

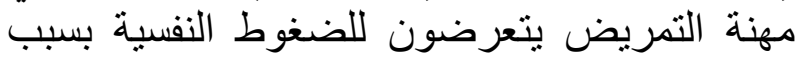
زيادة حجم العمل لديهم، وبسبب التمبرون عدم تناغم بين الحياة العملية و الحياة الاجتماعية، وأوقات العمل الليلي، وفي لئي

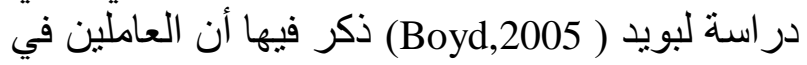

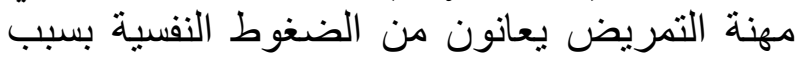

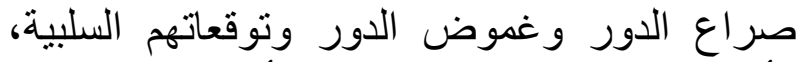

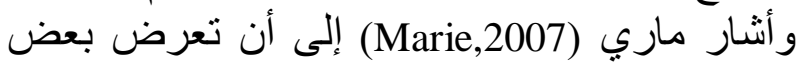
الممرضين للضغوط النفسية يجعلهم يشعرون بالعجز العزي عن تقديم العمل المطلوب وبالمستوى الذي يتوقئ الأخرون منهم، وذكر جودة (2003) أن الصحة الصدة النفسية للممرض و الممرضة وذنة تلعب دور هام في علاج

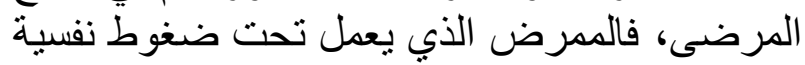

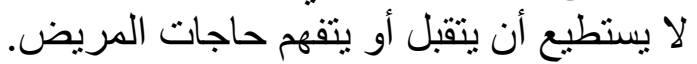

الفرد بتحويل المحتوى بطريقة تحدث تغير ات داخلية

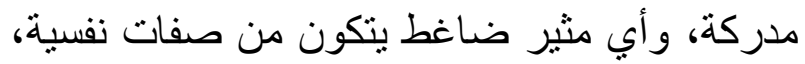

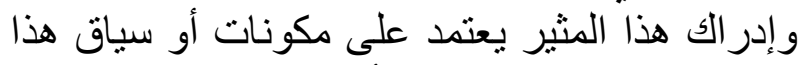

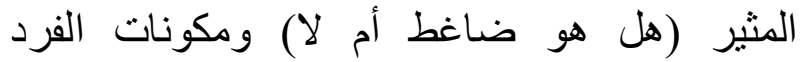
(شخصيته)، مثل الخبرة السابقة بهذا المثير، ولئ وهي تحدد مدى نجاح الفرد في التكييف، وتُعد الأفكار

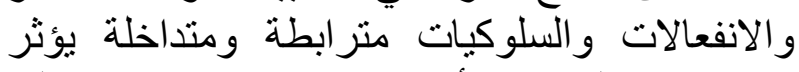
بعضها في البعض الأخر ، والاضطيات منرابطة ابات الانفعالية

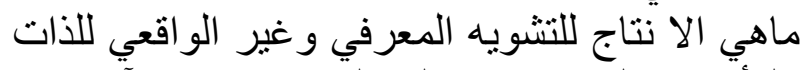

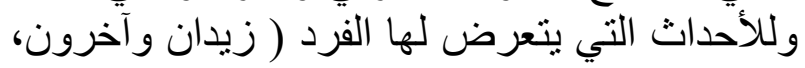
2017)

أن تفسير الأحداث و إدر اكها هو الموضوع الأساسي

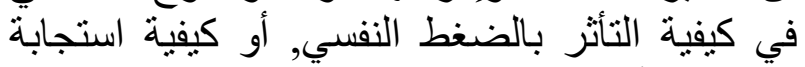

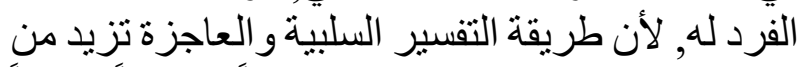
الضغط النفسي ونتائجه السلبية سلوكياً وجسدياً ونفسياً (Lazarus \& Folkman, 2003, P.61) مستويات الضغط النفسي تبعاً لتنوع العمل وطبيعته,

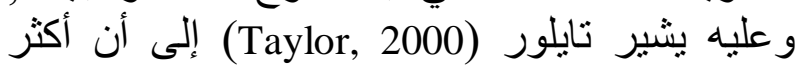
مجالات العمل إثارة للضغورة تلألك التي تمتاز بمو اجهة

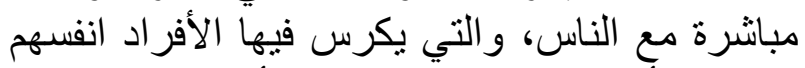

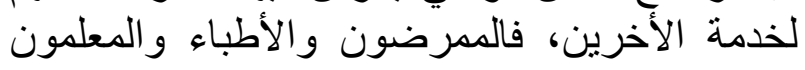

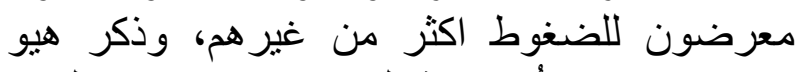

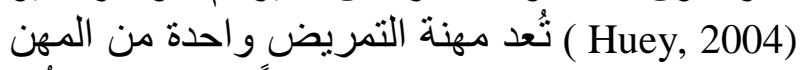

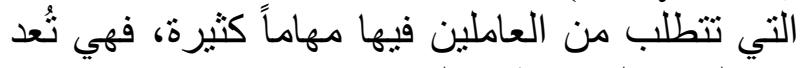

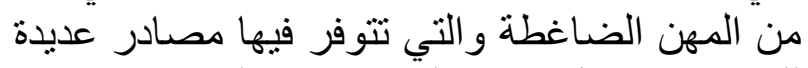

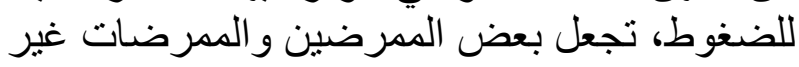

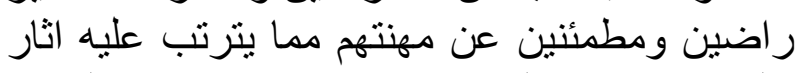
سلبية تنعكس على كفاءة ذاتهم وتوافقهم النفسي عهني

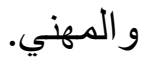
ويؤكد آليس ( Ellis,1990) على أهمية ما ور اء التقييم

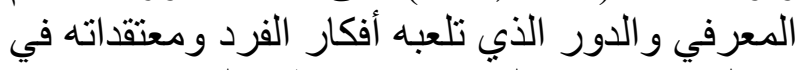

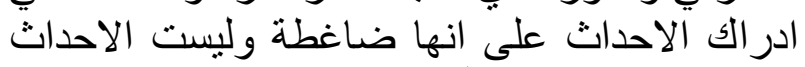

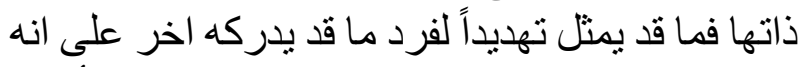
تحدي لقدر اته، وبذلك من المحتمل إذا تبنى الفرد أفكار غير منطقية و غير عقلانية سوف يقوم بتفسير الاحداث بصورة غير صحيحة ومن ثم تبنى أساليب للمو اجهة بهنة

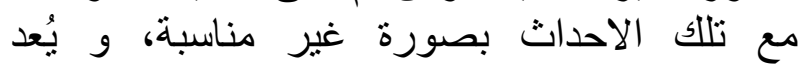
الممرضين و الممرضات شريحة مهمة وتقدم خدمات 
الأفكار اللاعقلانية تعزى لمتغيري الجنس والحالة الاجتماعية؟

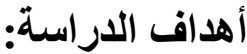
1. التعرف على العلاقة الارتباطية بين الضغوط الضاطية النفسية والأفكار اللاعقلانية لدى العاملين لإلين مهنة التمريض في مستشفى ومراكز الرعاية الأولية لألية بمحافظة القويعية. 2. التعرف على مستوى الضغوط التئية النفسية لاى العاملين في مهنة التمريض في مستشفى ومر اكز الر عاية الأولية بمحافظة القويعية. 3. التعرف على مستوى انتشار الأفكار اللاعقلانية

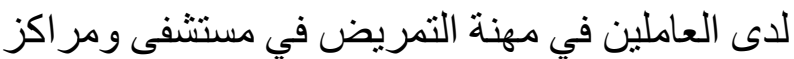
الر عاية الأولية بمحافظة القويعية. أهمية الدراسة: تأتي أهمية الدر اسة من الناحية النظرية من خلال القاء الناء

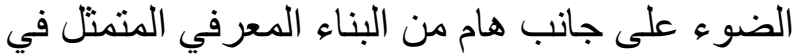

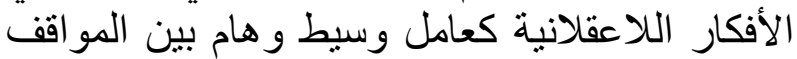

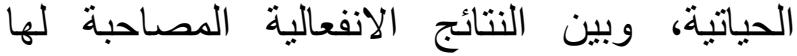
و والمنمثلة في الضغوط الضينة النفسية. وينظر الباحث أن تشكل الدراسة الحالية إضافة

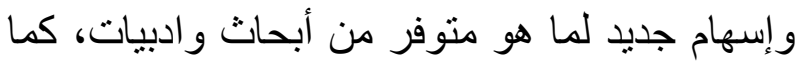

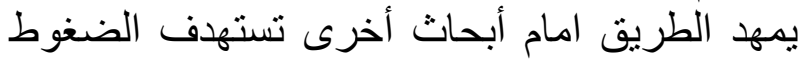
النفسية وعلاقتها بالأفكار اللاعقلانية لدى عينات

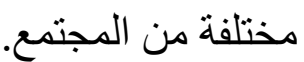
وتتمثل الأهمية التطبيقية للار اسة من خلال الاستفادة

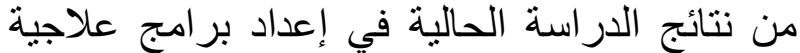
وارشادية لخفض الضغوط النفالنية النفسية، ولتنمية الأفكار العقلانية والوقاية من تبني أفكار لا لا عقلانية تؤدي النياني لاحقاً إلى اضطر ابات نفية نفية. حدود الدراسة:

- الحدود الموضوعية: وتتمثل في التعرف على الإن الضغوط النفسية وعلاقتها بالأفكار النلاعقلانية لدى فئي

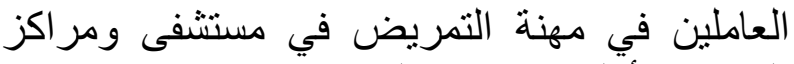
الر عاية الأولية بمحافظة القويعية.

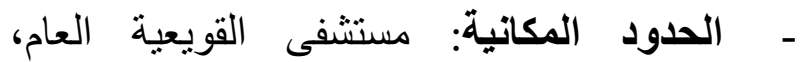
ومر اكز الرعاية الأولية بمحافظة القويعية والمر اكزية المئية

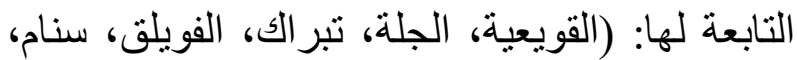

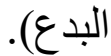

ويرى اليس (Ellis,1990) أن الأفكار للاعقلانية وما

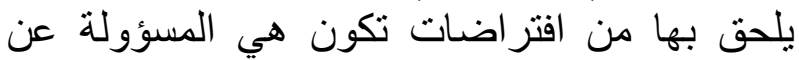

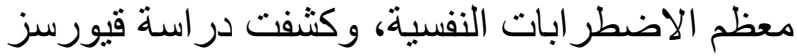
(Gurses,2005 )

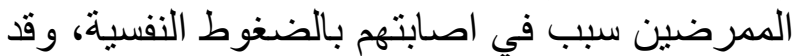
شعر الباحث من خلال عمله اخصائياً نفسياً متعاوناً في العيادة النفسية بمستشفى القويعية العام بشكاوي

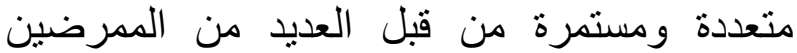

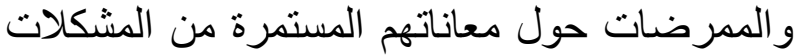

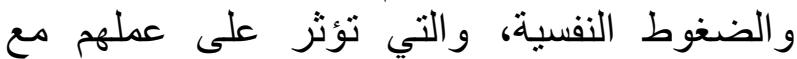
المرضى، وجاءت فكرة هذه الدراسة في محاولة النة

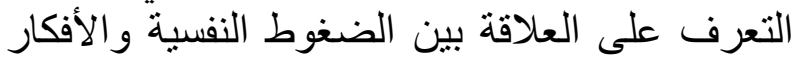

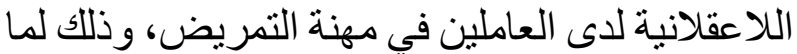

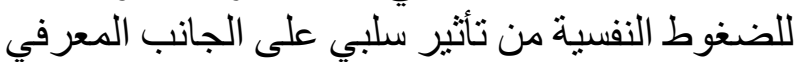

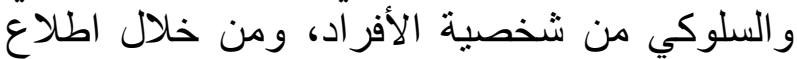

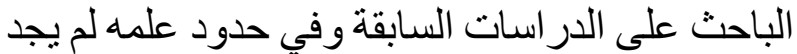

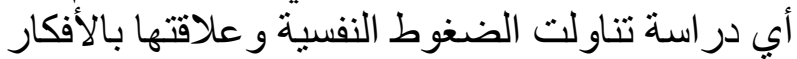
اللاعقلانية لدى العاملين في مهنة التمريض في في البيئة

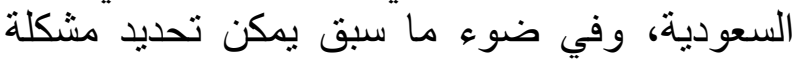
الار اسة في السؤال الرئيس التالي:

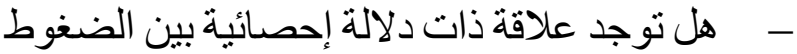
النفسية والأفكار اللاعقلانية لاى العاملية إحلين في مهنة

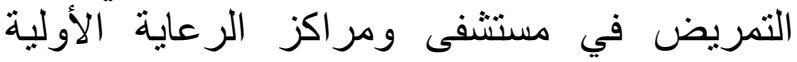
بمحافظة القويعية؟ ت تساؤلات الدراسة: 1. ما مستوى الضغوط النوان النفسية لدى العاملين في مهنة التمريض في مستشفى ومر اكز الرعاية الأولية بمحافظة القويعية؟ 2. ما مستوى انتشار الأفكار اللاعقلانية لاى فيع

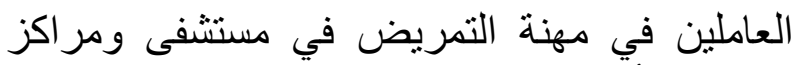
الر عاية الأولية بمحافظة القويعية؟

3. هل توجد فروق ذات بل دلالة إحصائية بين منوسط درجات العاملين في مهنة التمريض دات على مقياس الضغوط النفسية تعزى لمتغيري الجنس والحئي الاجتماعية؟ 4. هل توجد فروق ذات دلاتلة إحصائية بين متوسط درجات العاملين في مهنة التمريض فلى على مقياس 
يبذل مجهوداً لكي يتكيف مع الظروف الخارجية

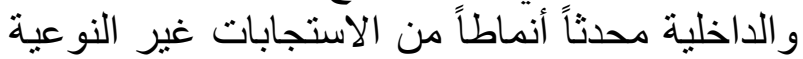
التي تحدث حالة من الألم، وعرفها لأنهات سولفان بأنها تحدي عوامل غير سارة (Sullivan, 2011)

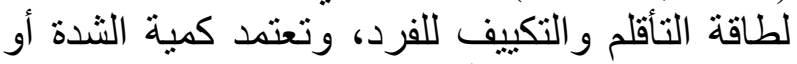

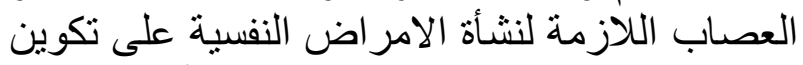

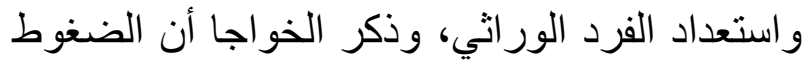

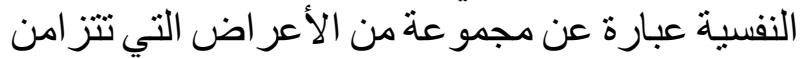

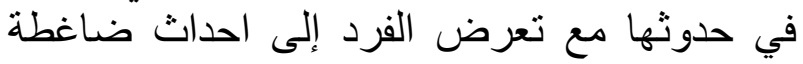

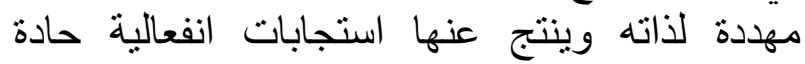

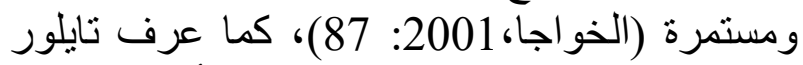
(Taylor,2000) عدم التوازن العقلي و الانفعالي و الجسدي للفرد، الفي وهو الفها

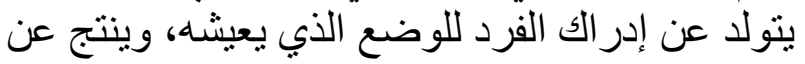

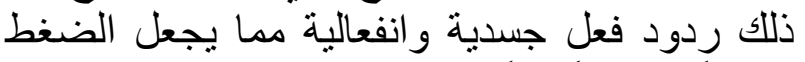

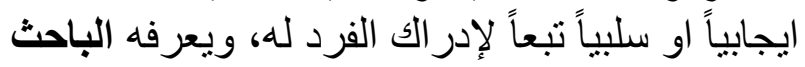

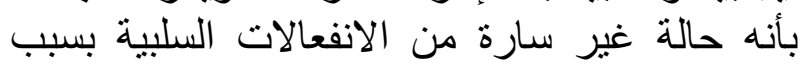

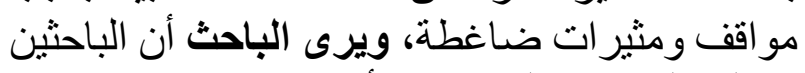

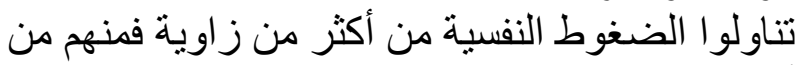
أدخل الجانب الفسيولوجي كتعريف (John,2007)،

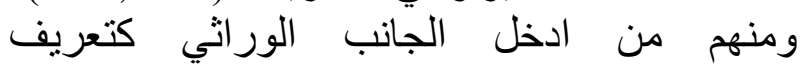
(Sullivan,2011)، ومنهم من ادخل الجانب الانفعالي الجي كتعريف الخو اجا (2001). مصادر الضغوط النفسية:

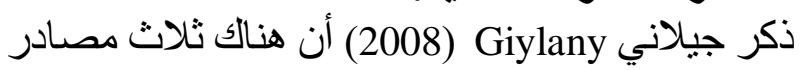
رئيسية للضغوطي الناني النفسية هي: 1. الإحباط: وهو الحالة الآنفعالية التي يمر بها الفرد

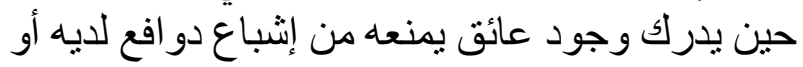

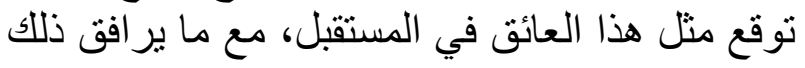
من تهديد وتوتر نفسي. 2.

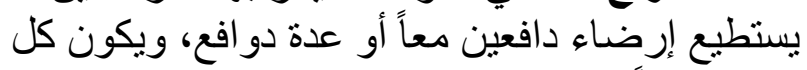

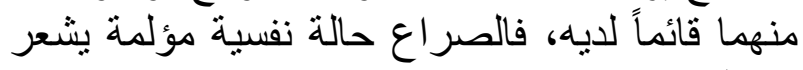

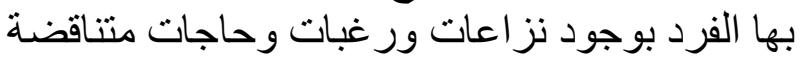
لا يمكن تحقيقها معاً.

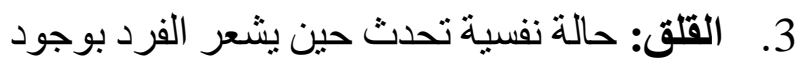

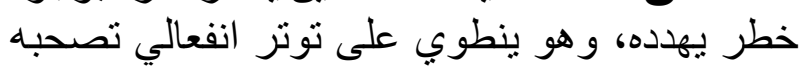
اضطر ابات فسيولوهية.

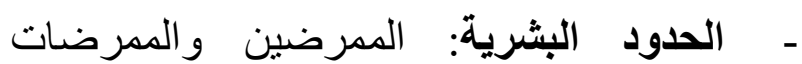
العاملين في مستشفى القويعية العام، ومر اكز الرئية الرعاية الأولية بمحافظة القويعية.

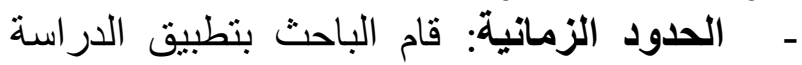

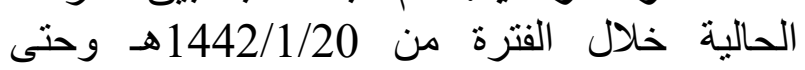
1442/3/11 هـ مصطلحاث الدراسة: 14/3/11

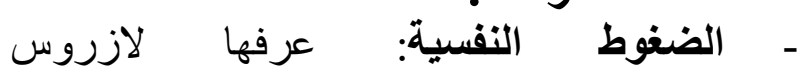
(Lazarus,2006)

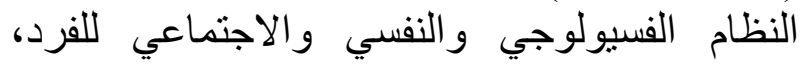
و الضغوط النفسية هي نتاج تقييم المواني الفي الفي المهددة و التي يختلف تأثير ها من فرد إلى ألى أخر.

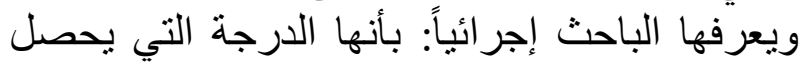

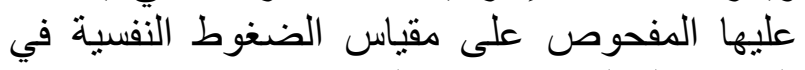

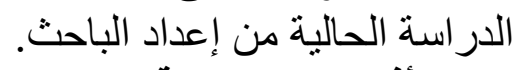

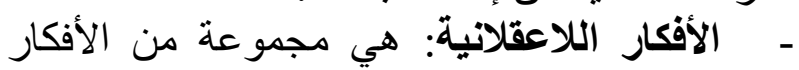

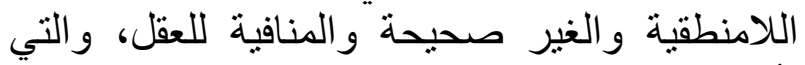

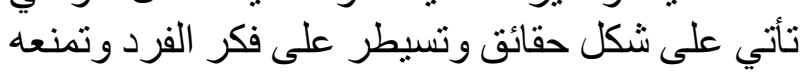
من الوصول إلى أهدافه (Alfano,2006).

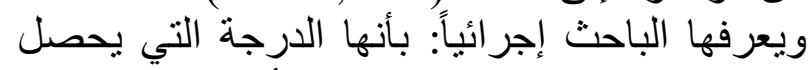
عليها المفحوص على مقياس الأفكار اللإعقلانية التهانية المستخدم في الدراسة الحالية من إعداد سليان الإنيمان الريحاني (1985). العاملين في مهنة التمريض: (1985) يعرفه جودة (2003) " الذكر أو الأنثى الذي منئ تخرج

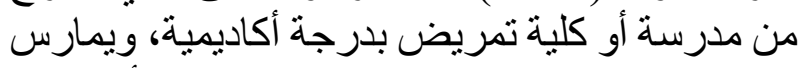

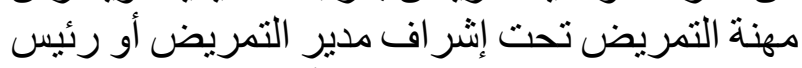

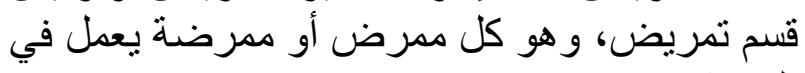
المستشفيات. ويعرفها الباحث: هو كل ممرض أو ممرضة مؤهل

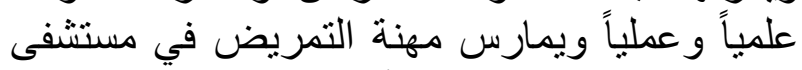
القويعية ومر اكز الرعاية الأولية بمحافظة القوية ويعية.

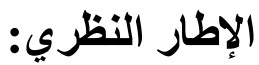
مفهوم الضغوط الإطي: النفسبة:

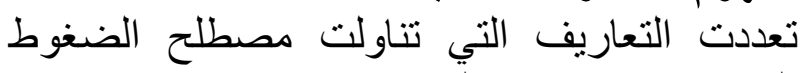
النفسية وسيستعرض الباحث مجمو عة منها:

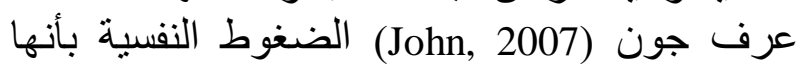
استجابة فسيولوجية ترتبط بعملية التكيف، فالجسم 
هـ تحديد مستوى الاستجابة.

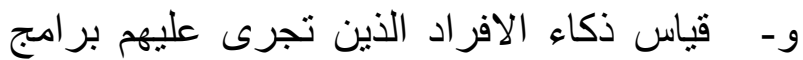

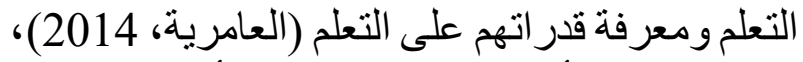
ويرى الباحث أن الضغط النفسي ينشأ عندما يواجه أنها الفرد الموقف ويتم تقيمه مبدئياً على أنه مصدر تهدي النها عنديد

2. نظرية لازرواس وفولكمان ( \& (Folkman ويرى لازروس وفوله ولكمان بأن البيئة تؤثر

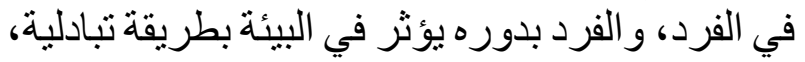
ويوجد ثلاثة مكونات للضغط النفسي وهي الموني الموقف

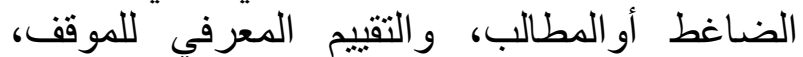

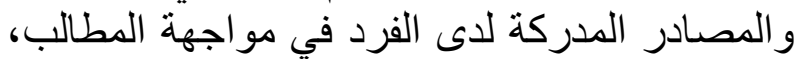

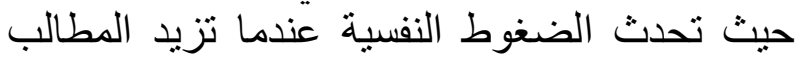
البيئة على قدرات الفرد على المواجهة (عبدالرحيم، 6(2011

3. النظرية المعرفية لبيك Beck: وقال بأنه يوجد ماتك

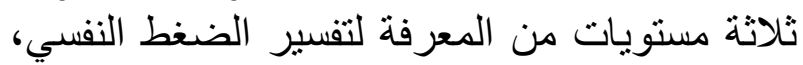

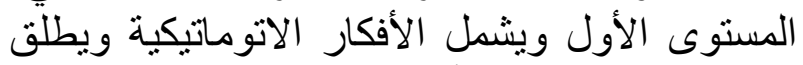

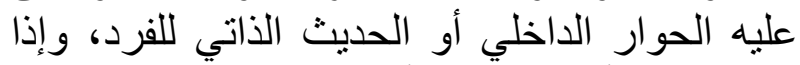
كانت هذه الأفكار سلّبية فأنها تسبب الضئ الضغط النفسي، أما في المستوى الثاني تأني العمليات المعرفية فئنية

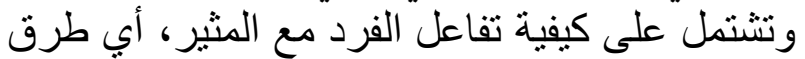

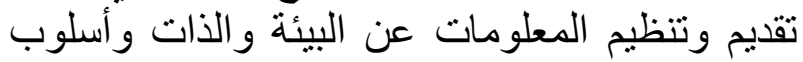

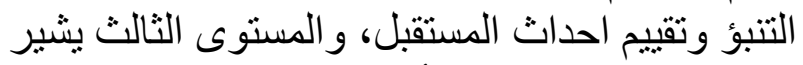
إلى التركيبات المعرفية أو المخططات، وهي وهي عبارة

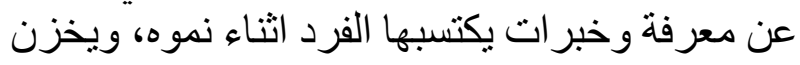
هذه المعرفة على شكل صيخ على علية ثنابتة تسمى المخططات، و إذا كانت هذه المخططات محبطة فإنها تخلق أفكار سلبية، و التي تأتي الفرد دون أن أن يلاحظها

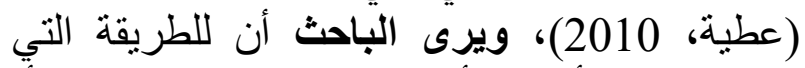

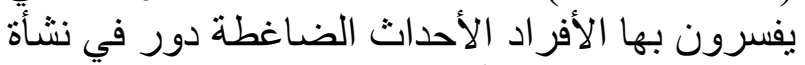

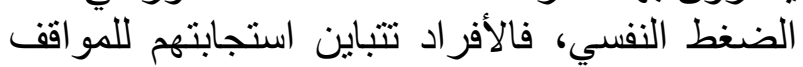
الضاغطة، نتيجة تباين خبر اتهم في الحياة. مفهوم الأفكار اللاعقلانية: نتيجة يعرف اليس (Ellis,1990) الأفكار اللاعقلانية بأنها الأفكار غير المنطقية التي تتميز بالمبالغةو التهويل في تفسير ها للحدث، والتي تعيق الفرد في حياته اليومية
ويرى الباحث أن مصسادر الضغوط النفسية تنشأ بناءً

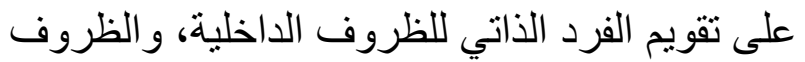

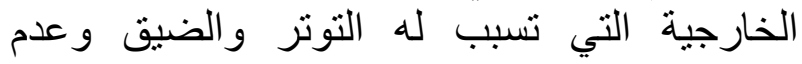
الارتياح.

النظريات المفسرة للضغوط النفاح النفسية: تعددت النظريات التي اهتمت بتفسير ظاهرة الضغوة الضغوط النفسية، وذلك تبعاً لاختلاف توجهات البهات الباحثين و العلماء، ومن أبرز هذه النظريات: نظرية هانز سيلي Hans seeley: يقول فيلئ سيلي أن الضغط النفسي هو استجابة لعيلة لعامل ضاغط، وراعتبر

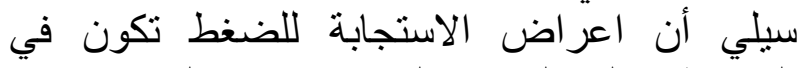

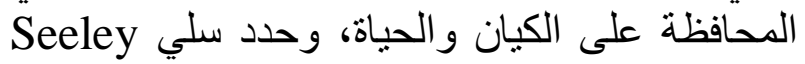

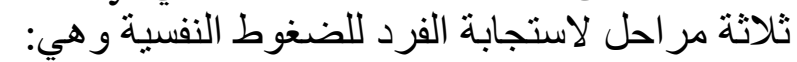
أ- مرحلة التببه والإنذار: وفيها لإنها بظهر الجسم تغيرات في خصائصه كنتيجة للتعرض الإلها المبدئي لب- للغط النفسي. مرحلة المقاومة: وتحدث هذه المرحلة عندما

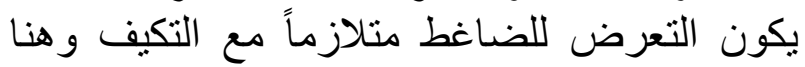
تختفي التغيرات التي ظهرت الترفي على الجسم، وتظهر تغير ات أخرى تدل على التكيف.

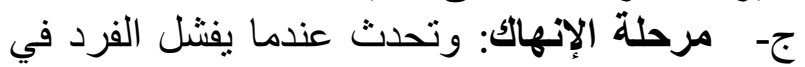

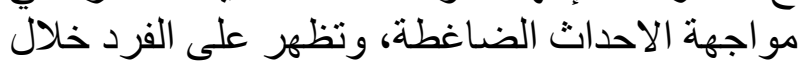
هذه المرحلة علامات الإرهاق وتتهار طاقته النفسية و الفسيولوجية (عريبات، 2005). ويرى الباحث أن لمستوى تكيف الفرد ميات، مع المواقف

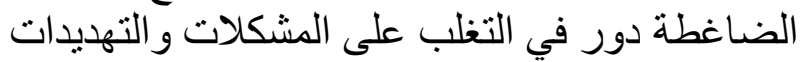
التي تو اجه الأفر اد.

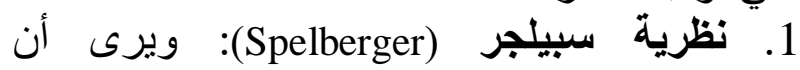
الضغوط لها دور مهم في إثارة الاختلافات على لهى

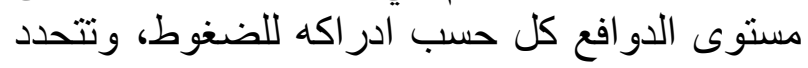
نظريته في ثناث محاور رئيسية و هي الضغط و والقلق

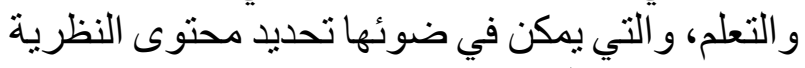
باختصار كما يلي:

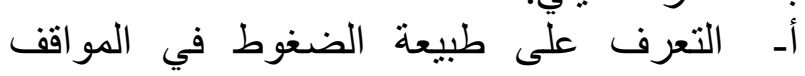
المختلفة. ب- قياس مستوى القلق الذي ينتج عن الضغوط. ج- قياس الفروق الفردية في الميل للقلق. د- توفير السلوك المناسب اللتخلب على القلى القلى. 
على بعضهما البعض، وفى بعض الأحيان فإنهما

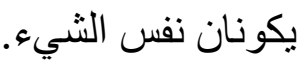
3- أن كل من التفكير والانفعال يميل إلى أن يكون

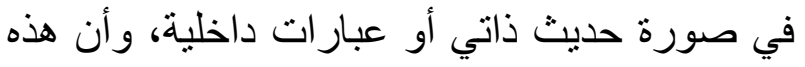
العبار ات التي يقولها الناس لأنفسهم تصبح هي نفسها

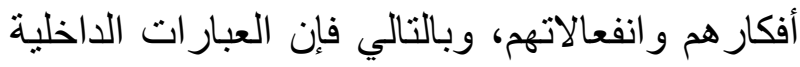

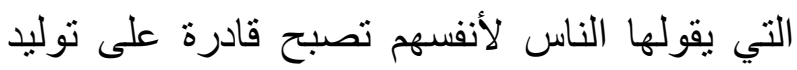
وتعديل الانفعالات.

ويرى اليس Ellis أن الانفعالات غير الملائمة مثل

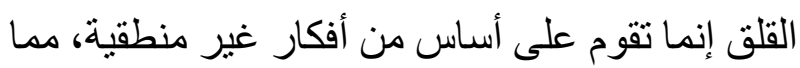

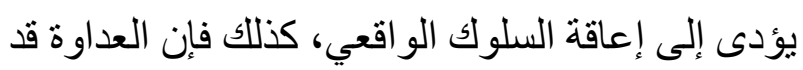
يكون لها جانب منطقي وأخر غير منطقي. فالجانب المنطقي منها يشتمل على الشعور بالضيق أو فئري

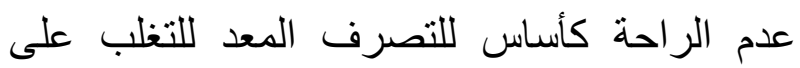
التذبذب، على حين أن الجانب غير العقلاني منها

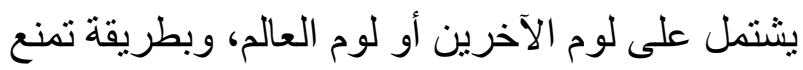
التصرف الفعال، وربما نولد المزيد من عدم السعادة للفرد. - م

ويرى الباحث أن اضطر اب التفكير لدى الفرد يتسبب في اضطر اب السلوك، نتيجة المعتقدات الخاطئة التي لئي

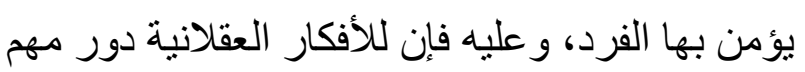
في تحقيق الصحة النفسية للأفر اد. وينظر اليس Ellis إلى البيئة و إلى مرحلة الطفولة على أنها تساعد ذلك الميل الفطري لتكوين الأفكار غير العقلانية ونمو ها، وفى عرضه لنظريته فإنه يحدد

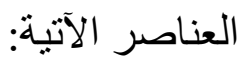

وتسبب له اضطر اباً نفسياً، كما اشارت (الصباح والحموز، 2007: 281) إلى أن الأفكار اللاعقلانية هي عبارة عن مجمو عة من الأفكار و المعتقدات التي التي

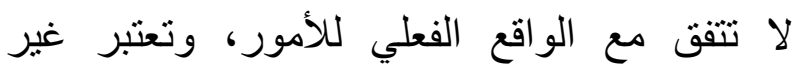
موضوعية، وتتميز بتعظيم الأمور المرتبطة بالذات و لأخرين، كما تعرف الأفكار اللاعقلانية بأنها مجموعة من الأفكار الخاطئة وغير المنطقية، والتي لتحري

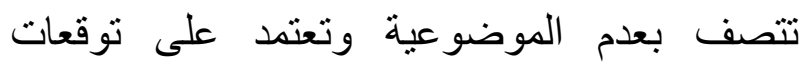

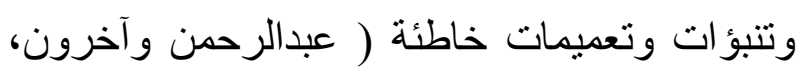

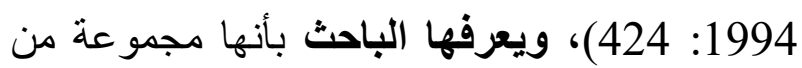
المعتقدات الغير منطقية، والأفكار اللاعقلانية، والتي وبرهي تعتمد على توقعات خاطئة وتنبؤات مبالغ فيها، ويرى ولئه الباحث أن جميع التعريفات التي تناولت الأفكار اللاعقلانية لم تتعدى ما ذكره اليس Ellis فالجميع اتفق على انها غير منطيقة و لا تتصل بالو اقع بأي صلة. ويرى اليس Ellis أن البشر يشتركون في غايتين

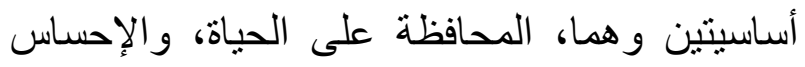
بالسعادة النسبية والتحرر من الألم، وأن العقلانية التهاية تتكون من التفكير بطرق تقف حجر عثرة في تحقيق

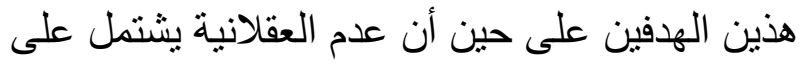
التفكير بطرق تقف حجر عثرة في سبيل تحقيقهما، وبذللك فإن العقلانية يمكن تعريفها على أنها استخدام المنطق في تحقيق الأهداف القريبة و البعيدة. ولقد وضع اليسEllis ثلاثة فروض أساسية لفهم هذه

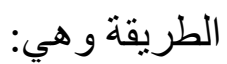
1. أن التفكير و الانفعال بينهما صلة وثيقة. 2. أن درجة الصلة بين التفكير و الانفعال من القوة

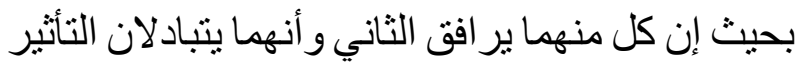


قامت هديوة (2018) بدر اسة هدفت إلى تحديد نوع

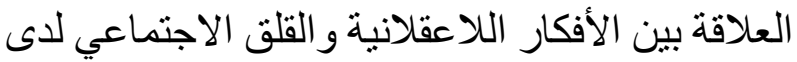
طلاب كلية التمريض في جامعة تثرين، وتكونت عينة الدر اسة من (300) طالب وطالبة، واستخدمت هابن الباحثة مقياس الأفكار اللاعقلانية إعداد سليمان الريحاني (1985)، ومقياس القلق الاجتماعي لكاثرين (Katherine,2000)، و الذي ترجمه إلى العربية اماني

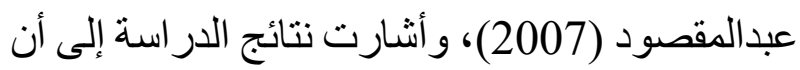

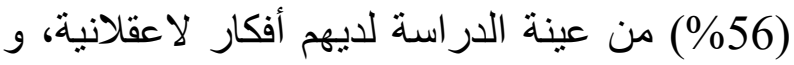
(98\%) لديهم قلق اجتماعي، كما أنشارت نتائج

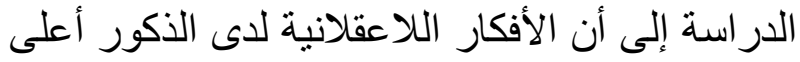

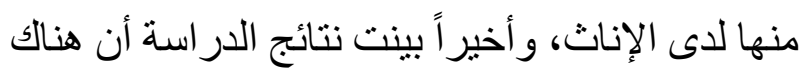
علاقة موجبة ودالة إحصائياً بين الأفكار اللاعقلانية

$$
\text { و القلق الاجتماعي. }
$$

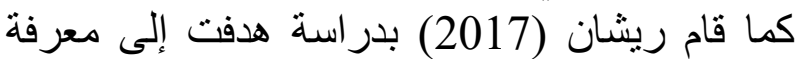
الضغوط النفسية وعلاقتها بالأفكار اللاعقلانية لدى الدى الني

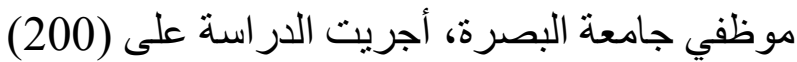

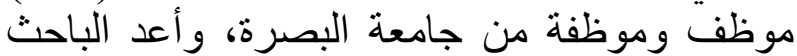

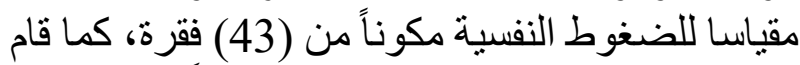

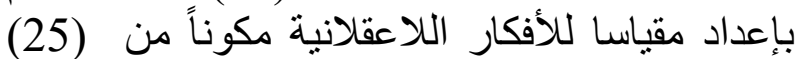

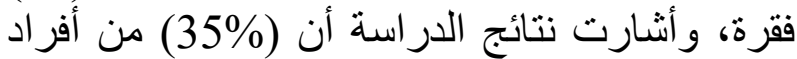

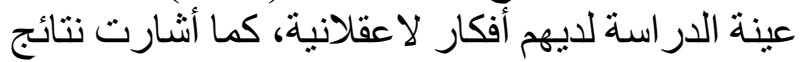

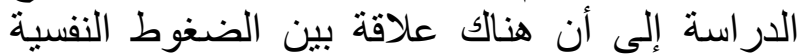

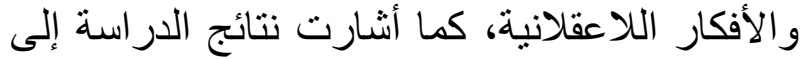
أن الموظفين الغير متزوجين لايهم أفكار لا عقان الانانية

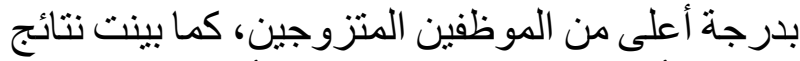
الدراسة أن الرجال تسيطر عليهم الأفكار اللاعقلانية التانية

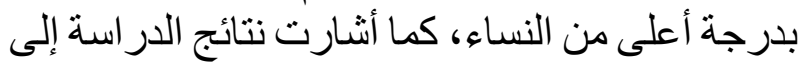

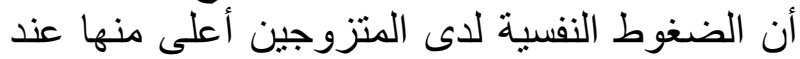

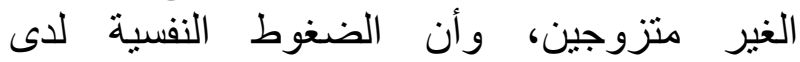
الممرضات أعلى منها لدى الممرضين.

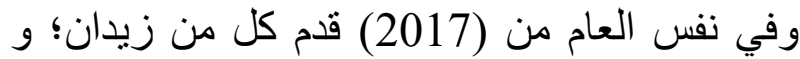
متولي؛ و الباز دراسة هدفت إلى التعرف على العلى العلاقة
إذا كان أ ( A ) هو الحدث أو الو اقعة المنشطة ،و الذي

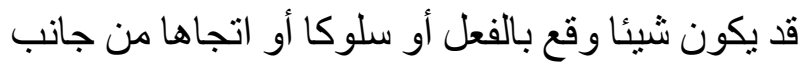
شخص آخر. وكانت ب ( B ) تللك الأفكار أو المقو لات التي يقولها

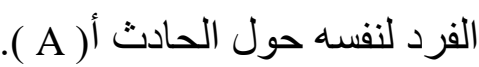
وكانت ج ( C ) هي النتيجة أو ردود الفعل التي يستجيب بها الفرد سو اء كان ذلك سعادة أو اضطر ابا انفعاليا. 1. فأنه في الو اقع يكون هذا الانفعال سواء كان انفعالا سار ا أو انفعالا غير سار ليس نتيجة للحدث الذي سبقه

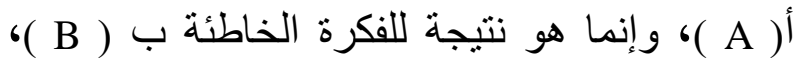

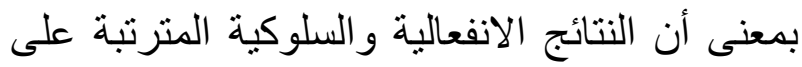
أحداث منشطة في حياتنا إنما يحكمها نظام التفكير لدينا ،و أن لدينا القرة على ضبط وتعديل أفكارنا ومن ثم

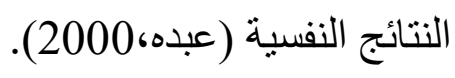

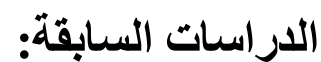

لم تتوفر حسب علم الباحث دراسة علمية منشوره تناولت الضغوط النفسية و علاقتها بالأفكار اللاعقلانية لدى العاملين في مهزة التمريض، لذلك سيستعرض الباحث مجموعة من الدراسات التي تناولت الضغوط النفسية و علاقتها بالأفكار اللاعقلانية لدى الموظفين

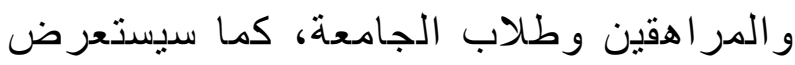
الباحث مجموعة من الدر اسات التي تناولت الضغوط النفسية لدى المدر ضين و الممرضدات، و اخير اً سيقوم الباحث بالتعقيب العام على هذه لهن الدر اسات وذلك على النحو التالي: 
نتائج الدر اسة إلى وجود علاقة ارتباطية دالة إحصائياً

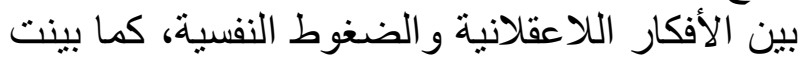

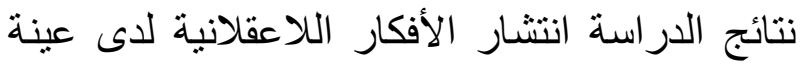

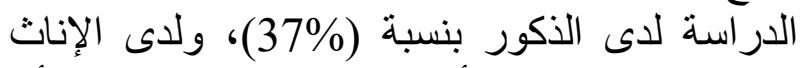

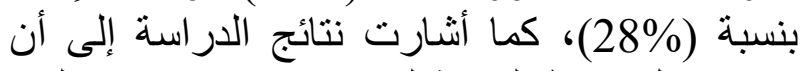
مسنوى الضغوط النفسية لاى الإناث (43\%) (41\%)، ولدى الثى الت الذكور (33\%).

ومن الدراسات التي تناولت الضغوط النفسية لدى

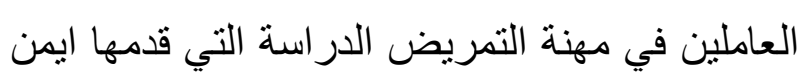

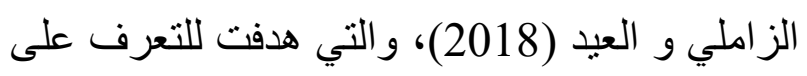
الضغوط النفسية لاى الممرضين العاملين في العناية

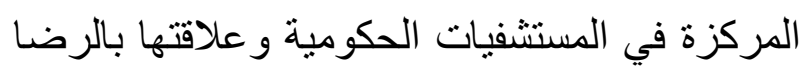

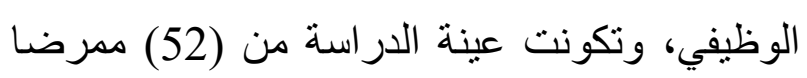

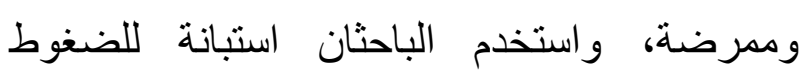

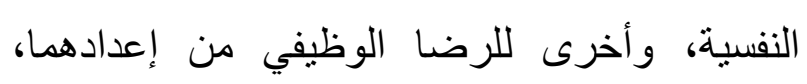

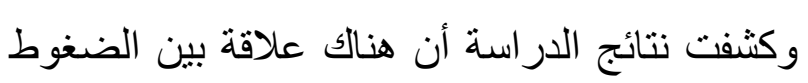

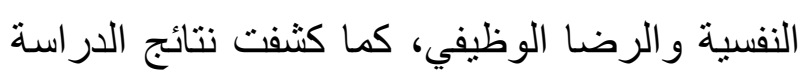
أن مستوى الضغوط النفسية لدى الممرضين

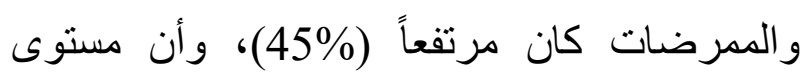

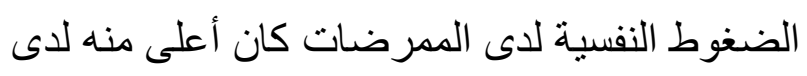

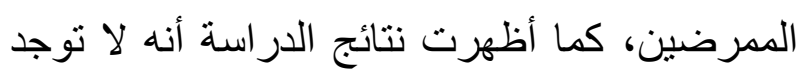

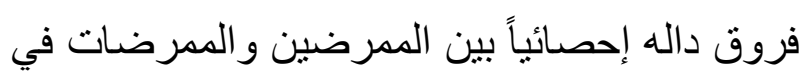

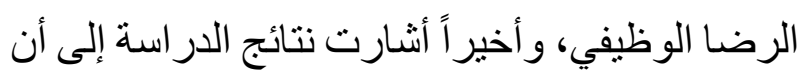
مستوى الضغوط النفسية لاى الغير متزوجين أعلى النى منه لاى المتزوجين. وفي نفس العام من (2018) قدمت الدعمس دراسة هدفت إلى التعرف على الضغوط النفسية وعلاقتها بالرضا الوظيفي و الاكتئاب لدى الأطباء و الممرضين

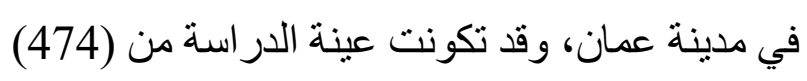
من الأطباء والممرضين، ولتحقيق أهداف الدراسة ولة فئة

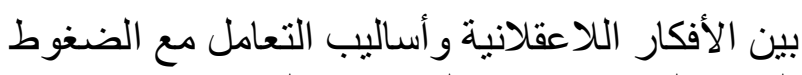

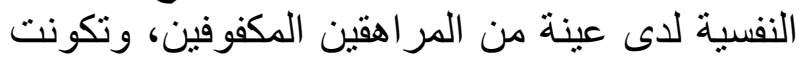

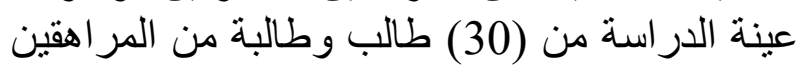

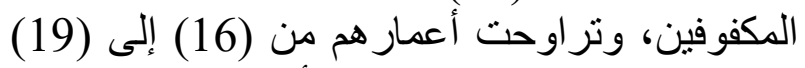

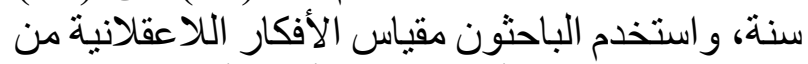

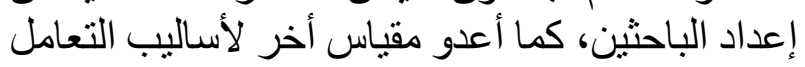

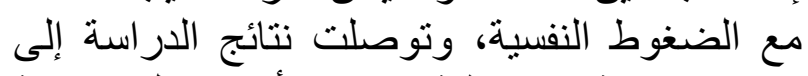

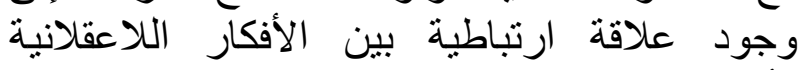

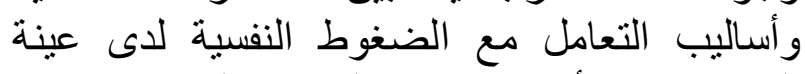

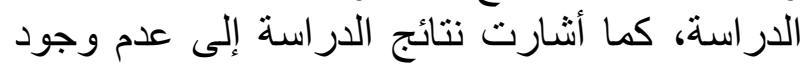

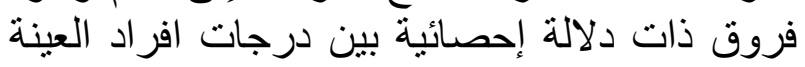

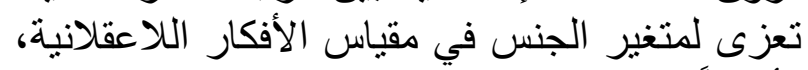

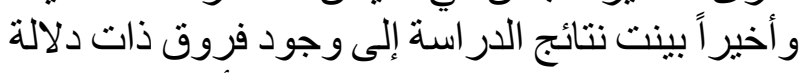

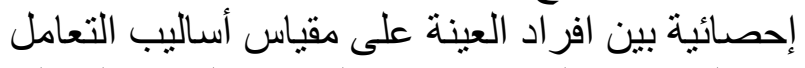

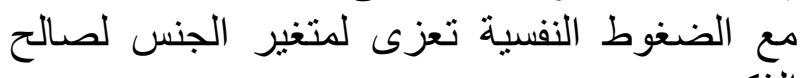

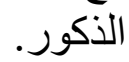

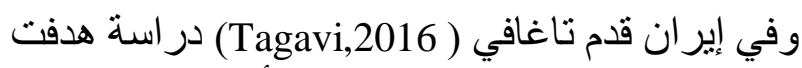
إلى التعرف على إلى الإلعلاقة بين الأفكار اللاعقلانية

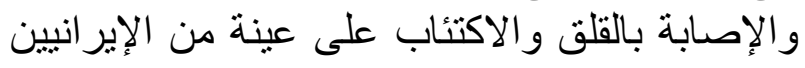

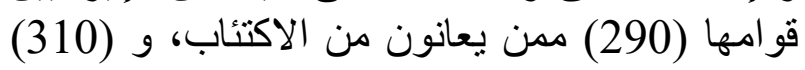

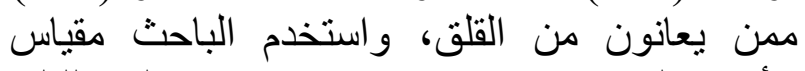

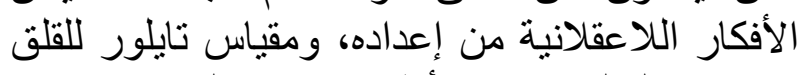

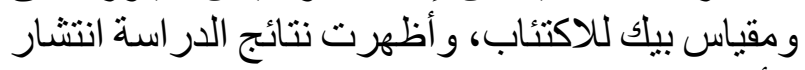

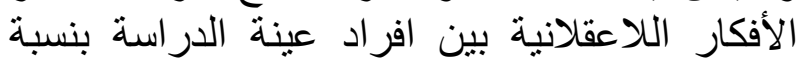

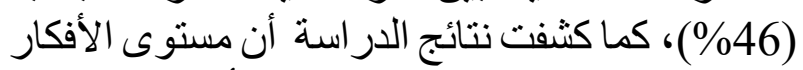

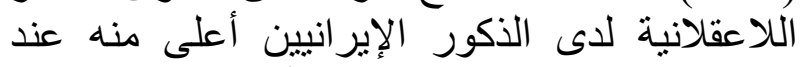

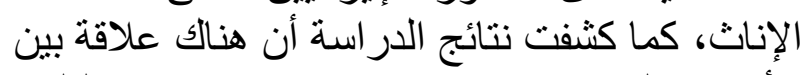

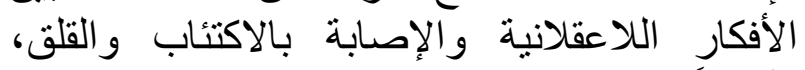

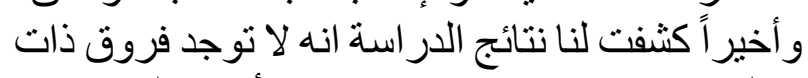

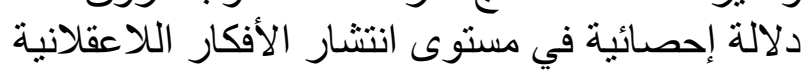

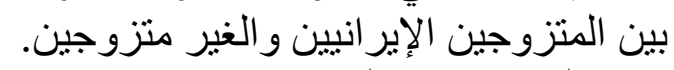

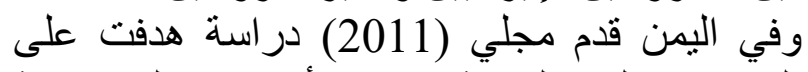

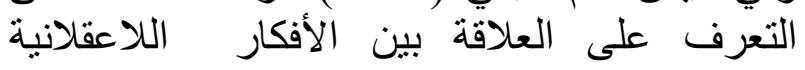
و الضغوط النفسية لدى طلبة كلية التربية بجامعانة

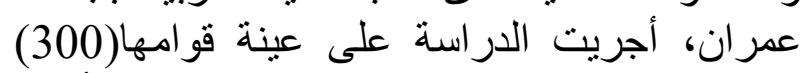
طالب وطالبة، استخدم الباحث مقياس العنة الأفكار اللاعقلانية من إعداد سليمان الريحاني (1985)، ومقياس قائمة الضغن إعوط من إعداد الباحثي، وتوصلت (1985، 
الضغط النفسي يرتبط بطول ساعات العمل، وبوجود أفكار لا منطقية وغير عقلانية لدى الممرضين،

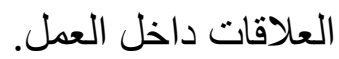

كما أجرى بورسيديجيان (Poursadeghiyan,2016) در اسة لتحديد العلاقة بين الضغوط النفسية و الاكتئاب و القلق و الرضا الوظيفي لاى المررضين، وتألفت التهابه

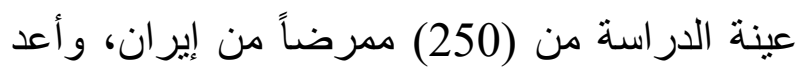
الباحث أداة لقياس الضغط النفسي و علاقتها بالاكتئاب و القلق و الرضا الوظيفي، و أظهرت نتائج الدر اسة أن نسبة (68\%) من الممرضين يعانون من ضغوط والفي

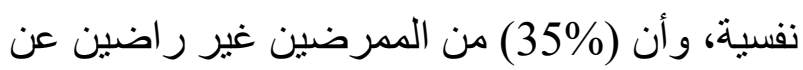
عملهم، وأن (7\%2\%) من الممرضين يعانون من من الاكتئاب، و أن نسبة (2\%، 2\%، 31) من الممرضين يعانون

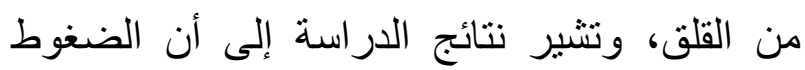

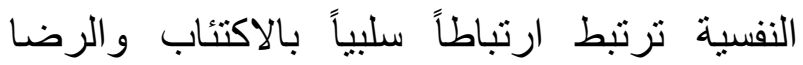

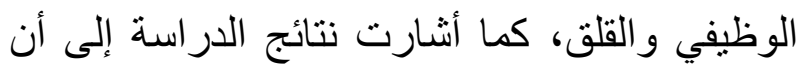

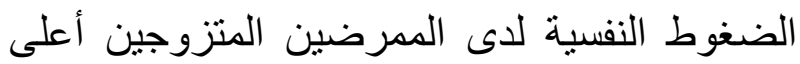

$$
\text { منها عند الغير متزوجين. }
$$

وفي نفس العام ولكن في كوريا الجنوبية أجرى نام ( Nam,2016) العمل والرضا الوظيفي على عينة من الأطباء و الممرضين، وتكونت عينة الدراسة من (287) طبيباً، و (205) ممرضاً يعملون في ثناث مستشفيات

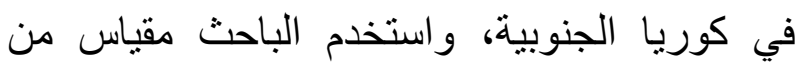
إعداده لقياس ضغوط العمل والرضا الوظيفي، و أنشارت نتائج الدر اسة إلى أن مستوى الضغط النف النفسي لاى الممرضين أعلى منه عند الأطباء، كما بينت نتائج الدراسة وجود ارتباط سلبي بين الرضا الوظيفي
استخدمت الباحثة ثلاثة مقاييس، قائمة بيك للاكتئاب، تم تطوير وتعريب مقياس مصادر الضغوط النفسية لجرقوف (Gregov,2011), وتعريب مقياس الرضا الوظيفي لر امسودي ( Ramasodi,2010), و أثنارت نتائج الدراسة إلى أن مستوى الضغط النئ النفسي لدى

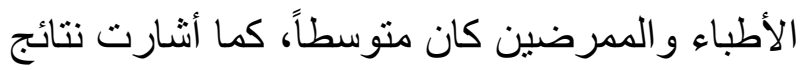
الاراسة إلى أن مصادر الضغط النفسي التي احتلت

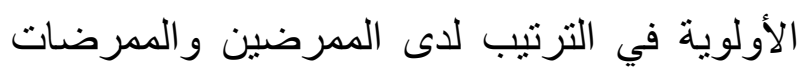

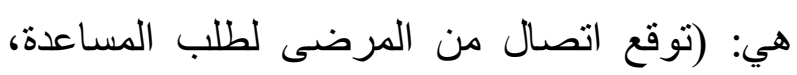

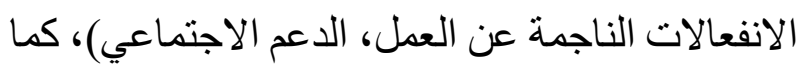
أنشارت نتائج الدراسة إلى فروق ذات دلاتلاتلة إحصائية في مستوى الضغط النفسي تعزى لمتغير الجنس

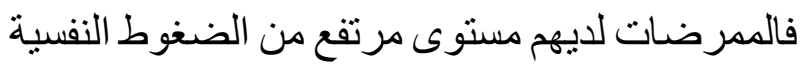

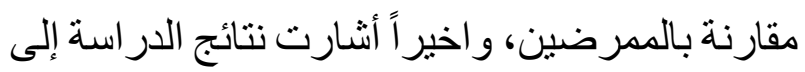

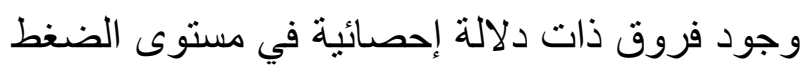

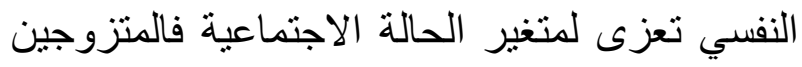
لديهم مستوى مرتفع من الضغوط النفسية مقارنة بالغير متزوجين. وفي عام (2017) قدم فانديفالا (Vandevala,2017)، دراسة هدفت إلى التعرف على الضغوط النفسية عند الممرضين والأطباء العاملين في وحدة العناية المركزة في ويلز البريطانية، وتأثنير هذه الضغوط في في وحني

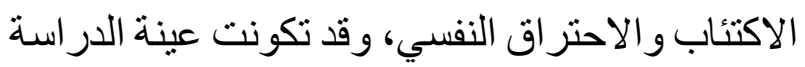
من (58) طبيباً، و (38) ممرضاً، وقد استخدم الباحث مقياس الضغوط النفسية من إعداده، و أنشارت نتائج

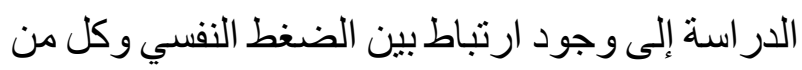
الاكتئاب والاحتراق النفسي وخطر الوقوع في في دائرة الاضطر اب النفسي، كما أثشارت نتائج الدر اسة إلى أن 
بين القيم الثخصية والتنظيمية، بيئة العمل، ساعات العمل الليلي، كما بينت نتائج الدر اسة إلى أن انخفاض الرضا الوظيفي لدى الممرضين اقترب بدرجة مرتفعة بالضغط النفسي فيما يتصل بجميع مجالات العمل، كما أشارت نتائج الدراسة أن الضغوط النفسية لدى بلى الممرضنات أعلى منها لدى الممرضين. التعقيب على اللدراسات السابقة:

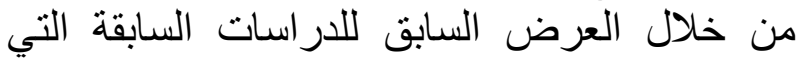

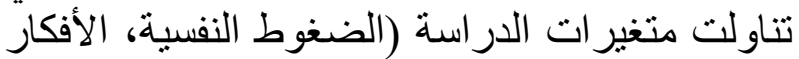
اللاعقلانية) لم يجد الباحث حتى إعداد هذا البحث در اسة بحثت العلاقة بين الضغوطة لإنة النفسية و الأفكار اللاعقلانية لاى العاملين في مهنة التمريضة، وبنة وبالتالي تسهم الدراسة الحالية وتضيف للإيف للار اسات السابقة في تناولها للضغوط النفسية و علاقتها بالأفكار اللاعقلانية لاى العاملين في مهنة التمريض، ولفية وعندما نتناول

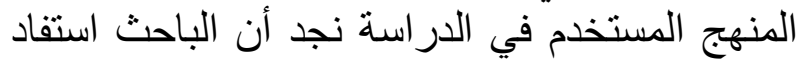

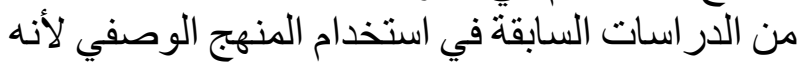

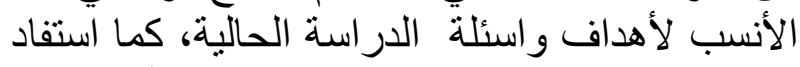

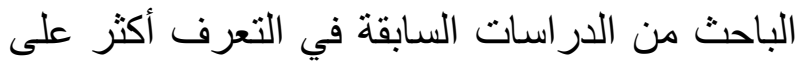

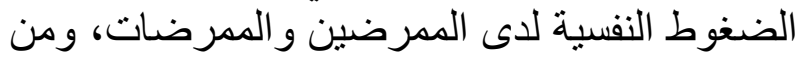

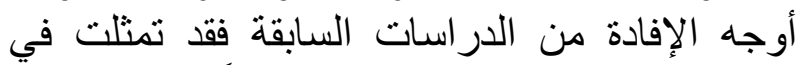
معرفة الضغوط النفسية الأكثر تأثثيراً على العاملين فئي

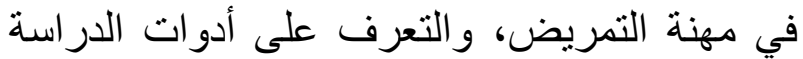
وكُيفية بنائها، بالإضافة إلى اسهامها في مناقنة نتائج الدر اسة. أما من حيث عينة الدراسة فالدراسات السابقة التي

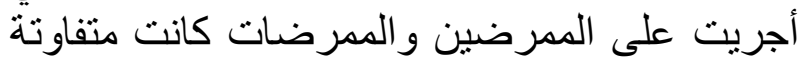

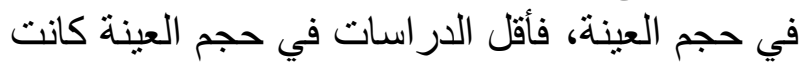

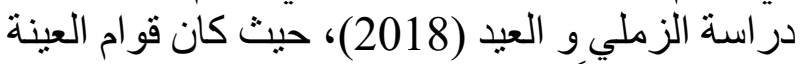

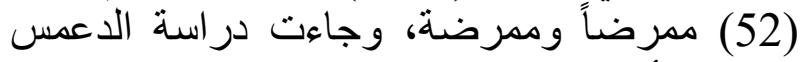
(2018) أكثر الدر اسات السابقة من حيث حجم العينة،

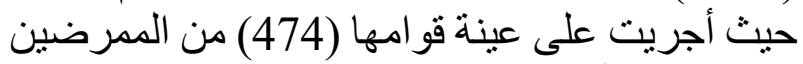

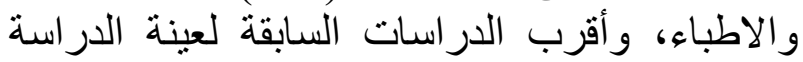

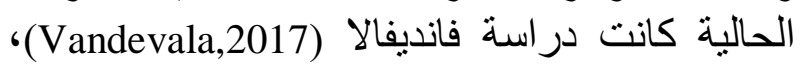
حيث أجريت على عينة قو امها (106) من المدرضين فاليف و الاطباء، وكذللك در اسة صبيرة عو إسماعيل (106) (2015)،
وضغوط العمل، كما أشنارت نتائج الدر اسـة أن أعباء العمل، وضعف التحكم في العمل، الحوافز المادية، و الأفكار اللاعقلانية من العو امل الأساسية في الإصـابة بالضغط النفسي لدى الممرضين. وفي در اسة قدمها صبيرة و إسماعيل (2015) هدفت إلى التعرف على الضغوط النفسية المهنية التي يتعرض عليها الممرضون و الممرضات العاملين في مسنشفى الأسد الجامعي وفقاً لمتغيري (الجنس، والحالة الاجتماعية)، وأجريت الدراسة على عينة قو امها (120) ممرضناً وممرضة من مختلف الأقسام في المستشفى، واستخدم الباحثان مقياساً للضغوط النفسية المهنية من إعدادهما، وأثارت النتائج إلى أن (\%649\%) من الممرضين و الممرضات يعانون من ضغوط نفسية، كما أنشارت نتائج الدراسة إلى أن الممرضات يعانين من الضغوط النفسية بدرجة أقل

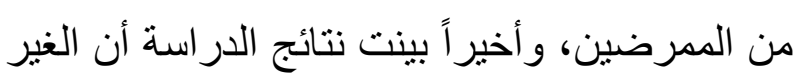
متزوجين من الممرضين والممرضات يعانون من الضغوط النفسية بدرجة أعلى من المتزوجين في البعد النفسي. وفي إيطاليا أجرى فيابان (Fiaban,2012) دراسة هدفت إلى التعرف على العلاقة بين كل من ضغط العمل و الرضا الوظيفي لدى الممرضين العاملين في الر عاية الصحية في وحدات إعادة التأهيل في إيطاليا، وقد تكونت عينة الدر اسة من (60) ممرضاً، و (43) ممرضة، وقد أعد الباحث مقياساً للتعرف على العلاقة بين ضغوط العمل والرضا الوظيفي، وكثفت نتائج الدر اسة أن مصادر الضغط الأساسية لدى الممرضين و الممرضات هي الثعور بغياب العدالة، والصراع 


\section{منهج وإجراءات الدراسة:}

- منهج الدراسة: استخدم الباحث المنهج الوصفي، بو اسطة أسلوب البحث الارتباطي للتعرف على طبيعة العلاقة بين الضغوط النفسية والأفكار اللاعقلانية لاى لإنى العاملين في مهنة التمريض في مستشفى القويعية العام ومر اكز الر عاية الأولية بمحافظة القويعية. - مجتمع الاراسة: يتمثل مجتمع الدراسة في لئل العاملين في مهنة التمريض بمستشفى القويعية العام

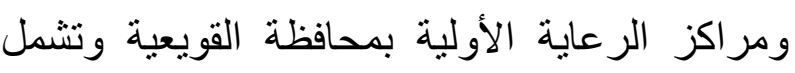

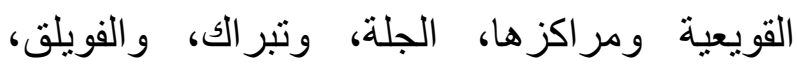

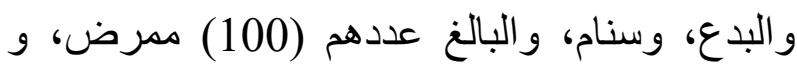

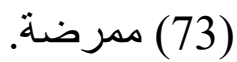

- عينة الدراسة: نم اختيار عينة البحث بطريقة العينة العشوائية البسيطة، حيث نم ترقيم ممرضي لئه مجتمع البحث من 1 1: 173 (للمرضين، و الممرضات) وكتابة الأرقام على قصاصنات ورقية ووضعها في صندوق، ثم تم سحب 125 ورقة بطريقة عشوائية ورقة تلو الأخرى لتمثل حجم العينة العشوائية البسيطة المختارة للبحث، واشتملت هذه العينة على (72) ممرضاً، و (53) ممرضة.

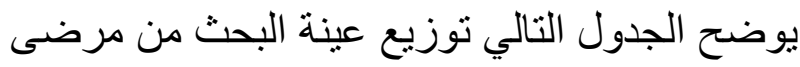

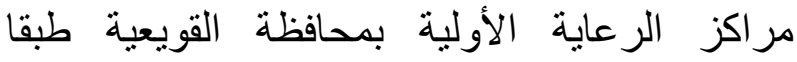
لمتغيري النوع و الحالة الاجتماعية.
حيث أجريت على عينة قوامها (120) ممرضاً وممرضة، و واستقلت الدر اسة الحالية بحجم عبنة قو امها (125) ممرضاً وممرضة.

ومن حيث الأدوات المستخدمة في الدراسات السابقة فقد ركزت أغلب الدراسات على أدوات من إعداد

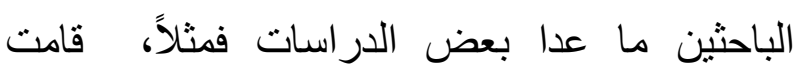
الدعمس (2018) باستخدام ثلاثة مقاييس، قائمة بيك الك للاكتئاب، ونم تطوير وتعريب لمقياس مصادر

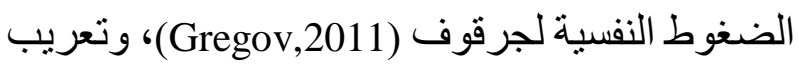

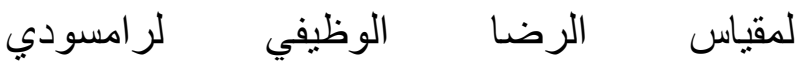
(Ramasodi,2010)، وفي دراسة مجلي (2011) استخدم الباحث مقياس الأفكار اللاعقلانية لسليمان

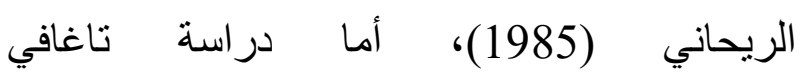
(Tagavi,2016) ومقياس بيك للاكتئاب، وفي دراسة هديوة (2018) استخدمت الباحثة مقياس الأفكار اللاعقلانية إعداد سليمان الريحاني (1985)، ومقياس القلق الاجتماعي التئه لكاثرين (Katherine,2000)، و والذي ترجمه إلى

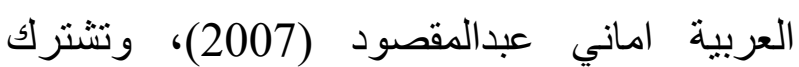
الدراسة الحالية مع دراسة مريم هديوة (2018)،

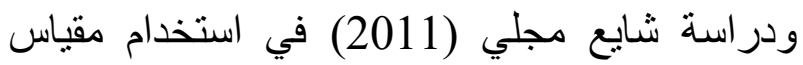

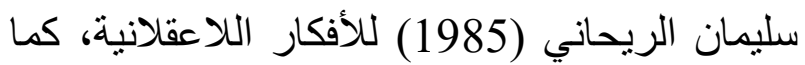

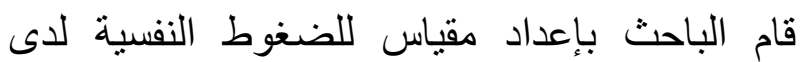
العاملين في مهنة التمريض.

جدول رقم (1): توزيع عينة الدراسة طبقا لمتغيري الجنس والحالة الاجتماعية:

\begin{tabular}{|c|c|c|c|c|c|c|}
\hline \multicolumn{2}{|c|}{ الاجمالي } & \multicolumn{2}{|c|}{ ممرضات } & \multicolumn{2}{|c|}{ ممرضين } & 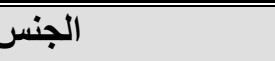 \\
\hline النسبة & العدد & النسبة & العدد & النسبة & 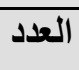 & الحالة الاجتماعية \\
\hline $56 \cdot 8$ & 71 & $60 \cdot 4$ & 32 & $54 ، 17$ & 39 & متزوج \\
\hline
\end{tabular}




\begin{tabular}{|c|c|c|c|c|c|c|}
\hline $43 ، 2$ & 54 & $39 \cdot 6$ & 21 & $45 \cdot 83$ & 33 & غير متزوج \\
\hline$\% 100$ & 125 & $42 ، 4$ & 53 & $57 ، 6$ & 72 & الاجمالي \\
\hline
\end{tabular}

ب- بعد تحديد مجالات المقياس من خلال الاطلاع على الدراسات السابقة، و عدد من مقاييس الضغوط النفسية ومنها مقياس ماسلاش للاحتراق النفسي ) Maslach Burnout,1981)

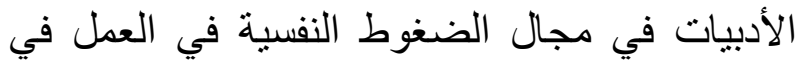

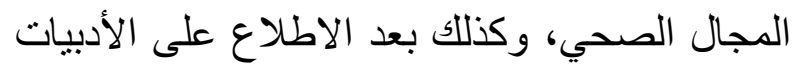
و الدراسات السابقة المتعلقة بشكلة الدراسة،

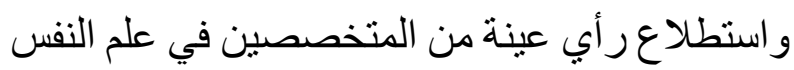
و الصحة النفسية عن طريق المقابلات الثخصبة ذات الطابع غير الرسمي قام الباحث بيناء فقر ات المقياس

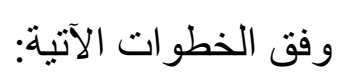

ـ تحديد الأبعاد الرئيسية التي شملها المقياس.

$$
\text { ـ صياغة الفقر ات التي تقع تحت كل بعد. }
$$

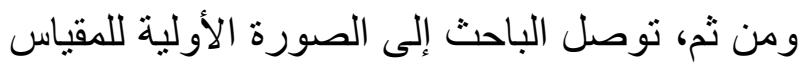

$$
\text { و التي شملت على (60) فقرة. }
$$

\section{الخصائص السيكومترية لمقياس الضغوط النفسية:}

قام الباحث بدراسة الخصائص السيكومثرية لمقياس الضغوط النفسية من خلال التعرف على صدق وثبات المقياس لدى العاملين في مهنة التمريض على النحو النالي:

\section{1 - 2 - nدق المقياس:}

أـ صدق المحكمين:

عرض الباحث المقياس بصورته الأولية على (15) من المحكمين بعضهم من المتخصصين في علم النفس، والبعض الأخر من أعضاء هيئة التدريس في لهن

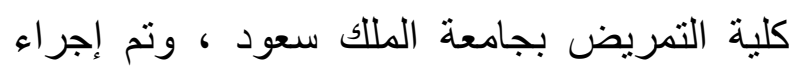

وتوضح نتائج الجدول أعلاه أن نسبة الممرضين

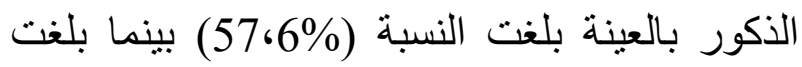
نسبة الممرضات النسبة (4\%،42)، كذلك بلغت نسبة المتزوجين من المرضين (17\%،54) في حين أن نسبة المتزوجات من الممرضات (4\%،60)، وكذللك بلغت نسبة غير المتزوجين من الممرضين النسبة (45،83\%)، كما بلغت نسبة غير المتزوجات النسبة

$$
\text { أدوات الدر اسة: }
$$

أولا: مقياس الضغوط النفسية لاى العاملين في مهنة التمريض (إعداد الباحث). تطلب البحث الحالي بناء مقياس خاص بمصادر الضغوط النفسية للعاملين في مهنة التمريض ومن لناه اجل ذلك قام الباحث بما يأتي: أ- إجر اء در اسة مسحية وذلك بهدف إعداد مقياس للضغوط النفسية للعاملين في مهنة التمريض، ونم ونم ذلك من خلال توجيه سؤالاً مفتوحاً على (205) ممرضاً

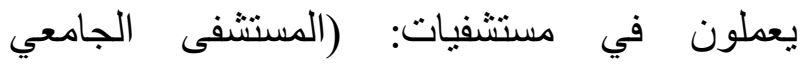
بالرياض، مستشفى الإيمان بالرياض، مستشفى الملك فهد بجدة، مستشفى القويعية العام) حيث طلب الباحث

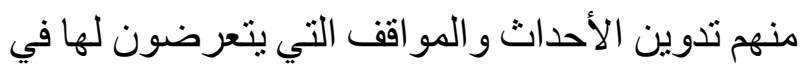

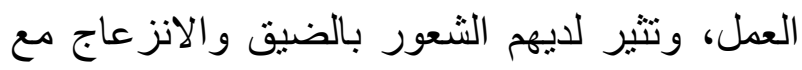
ذكر أمثلة لبعض المواقف. 
بذلك تتحصر درجات استجابات أفر اد عينة الدر اسة ما بين ( 132-44 ) درجة . ويوضح الجدول التالي توزيع فقرات مقياس الضغوط النفسية على أبعاده الفر عية.
التعديلات التي أوصى المحكمين بها من صياغة بعض الفقر ات و حذف العبار ات التي لم تحظى بنسبة اتفاق (90\%) فأكثر، و عددها (16) فقرة، إلى أن بلغ عدد فقرات المقياس في صورته النهائية ( 44) فقرة موزعة على خمسة أبعاد، حيث أعطى لكل فقرة وزن متدرج وفق سلم ثلاثي (غالباً، أحيانا، نادراً)، و أعطيت الفقرات الأوزان (3،2،1، لمعرفة مستوى الضغوط النفسية لاى العاملين في مهنة التمريض ، و

جدول رقم (2) يوضح توزيع فقرات مقياس الضغوط النفسية على الأبعاد الفرعية

\begin{tabular}{|c|c|c|c|}
\hline أرقام العبارات & عدد العبارات & 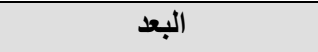 & r \\
\hline $13-1$ & 13 & الانفعالات الناجمة من العمل & 1 \\
\hline $21-14$ & 8 & بيئة العمل & 2 \\
\hline $32-22$ & 11 & العلاقات داخل العمل & 3 \\
\hline $39-33$ & 7 & الدعم الاجتماعي & 4 \\
\hline $44-40$ & 5 & الحو افز المادية & 5 \\
\hline
\end{tabular}

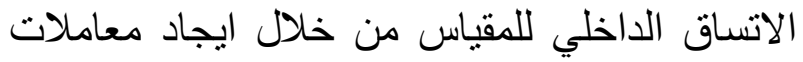

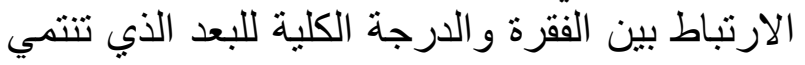

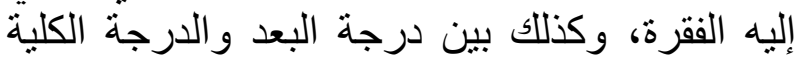

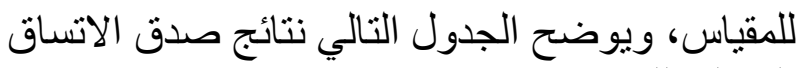
الداخلي للمقياس.
ب- صدق الاتساق الداخلي:

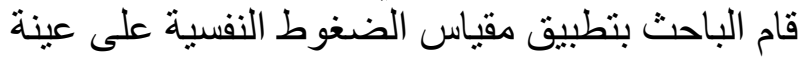

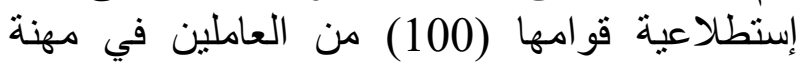

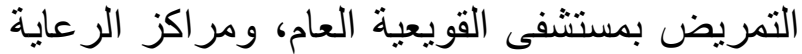

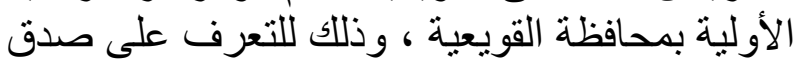

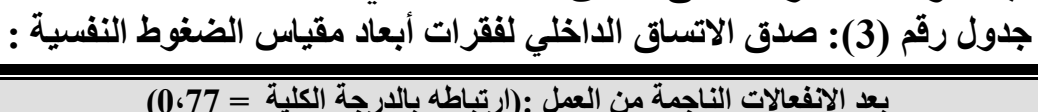

\begin{tabular}{|c|c|c|c|c|c|c|c|c|c|c|c|}
\hline \multicolumn{12}{|c|}{ بعد الانفعالات الناجمة من العمل :(ارتباطه بالدرجة الكلية = 77،0) } \\
\hline الارتباط & r & الارتباط & & م & \multicolumn{2}{|c|}{ الارتباط } & b & الارتباط & r & الارتباط & b \\
\hline$* * 0 \cdot 84$ & 13 & $* * 0 \cdot 82$ & \multicolumn{2}{|c|}{10} & \multicolumn{2}{|c|}{$* * 0679$} & 7 & $* * 0 \cdot 65$ & 4 & $* * 0$ 699 & 1 \\
\hline & & $* * 0,74$ & \multicolumn{2}{|c|}{11} & \multicolumn{2}{|c|}{$* * 0 ، 86$} & 8 & $* * 0$ *60 & 5 & $* * 0 ; 61$ & 2 \\
\hline & & $* * 0.75$ & \multicolumn{2}{|c|}{12} & \multicolumn{2}{|c|}{$* * 0 \cdot 81$} & 9 & $* * 0$ *68 & 6 & $* * 0 ، 62$ & 3 \\
\hline \multicolumn{7}{|c|}{ العلاقات داخل العمل (ارتباطه بالارجة الكلية= 7400) } & \multicolumn{5}{|c|}{ بعد بيئة العمل:(ارتباطه بالدرجة الكلية= 79،0) } \\
\hline الارتباط & b & الارتباط & م & \multicolumn{2}{|c|}{ الارتباط } & b & \multicolumn{2}{|r|}{ الارتباط } & b & الارتباط & 5 \\
\hline$* * 0.57$ & 9 & $* * 0 \cdot 70$ & 5 & \multicolumn{2}{|r|}{$* * 0675$} & 1 & & $* * 0$ 699 & 5 & $* * 0.73$ & 1 \\
\hline$* * 0$ 63 & 10 & $* * 0.55$ & 6 & \multicolumn{2}{|r|}{$* * 0$ 64 } & 2 & & $* * 0 ; 66$ & 6 & $* * 0 \cdot 66$ & 2 \\
\hline$* * 0676$ & 11 & $* * 0.66$ & 7 & \multicolumn{2}{|r|}{$* * 0679$} & 3 & & $* * 0 ، 80$ & 7 & $* * 0 ، 80$ & 3 \\
\hline & & $* * 0 ، 75$ & 8 & \multicolumn{2}{|r|}{$* * 0,72$} & 4 & \multicolumn{2}{|c|}{$* * 0670$} & 8 & $* * 0.76$ & 4 \\
\hline \multicolumn{5}{|c|}{ الحوافز (ارتباطه بالارجة الكلية = 78،0) : } & & & \multicolumn{5}{|c|}{ الاعم الاجتماعي (ارتباطه بالدرجة الكلية = 68،0) : } \\
\hline
\end{tabular}




\begin{tabular}{|c|c|c|c|c|c|c|c|c|c|}
\hline الارتباط & م & الارتباط & 5 & الارثباط & م & الارتباط & 5 & الارتباط & م \\
\hline$* * 0,72$ & 4 & $* * 0.83$ & 1 & $* * 0.67$ & 7 & $* * 0.54$ & 4 & $* * 0.69$ & 1 \\
\hline$* * 0,68$ & 5 & $* * 0.76$ & 2 & & & $* * 0$ 60 & 5 & $* * 0 \cdot 66$ & 2 \\
\hline & & $* * 0,71$ & 3 & & & $* * 0.67$ & 6 & $* * 0.71$ & 3 \\
\hline
\end{tabular}

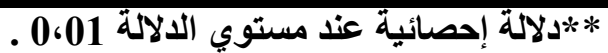

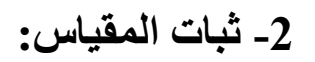
لقياس مدي ثبات أبعاد مقياس الضغان الضغوط النفسية، استخدم الباحث طرق التبات الثبات التالية. أسريقة إعادة التطبيق: قام الباحث بحساب معادة التطبئ الثبات للارجة الكلية

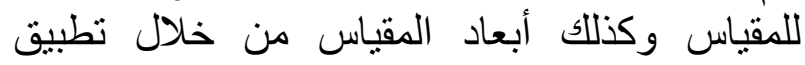
المقياس على العينة الاستطلاعية ثم إعادة نطبيق المقياس بعد فترة زمنية مدتها ثلاثة أسابيع على العيل العينة

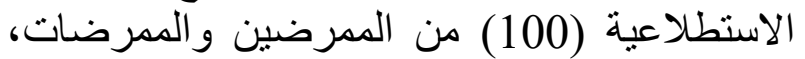
و أوضحت النتائج ارتفاع قيم معاملات المعرضين الثبات لأبعاد

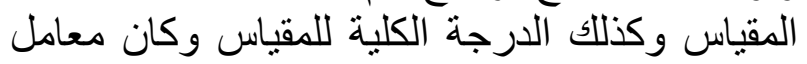
الثبات للارجة الكلية وكذللك أبعاد المقياس كما بالجدول

رقم (3).
وتوضح نتائج الجدول أعلاه أن قيم معاملات الارتباط

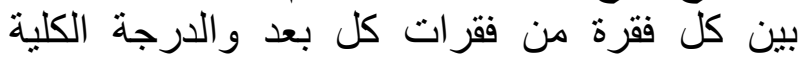

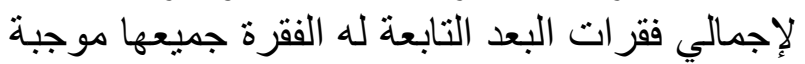
ودالة إحصائيا عند مستوى الدلالة ( ذللك وجود علاقة ارتباط موجبة ودالة التانة إحصائيا بين

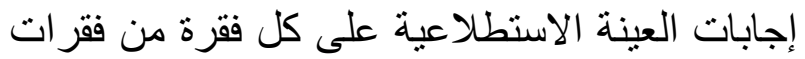

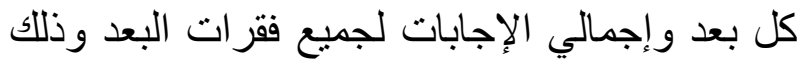

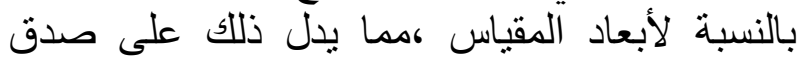

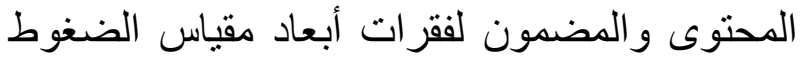

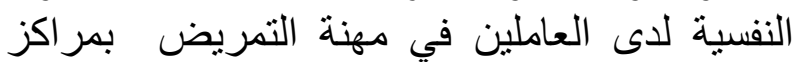
الر عاية الأولية بمحافظة القويعية و مستثفى القويعية التئية

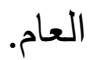

جدول (4) يوضح معاملات الثبات بطريقة إعادة التطبيق لمقياس الضغوط النفية

\begin{tabular}{|c|c|}
\hline معامل الثبات & البعد \\
\hline 0.81 & الانفعالات الناجمة من العمل \\
\hline $0 \cdot 77$ & بيئة العمل \\
\hline $0 ، 86$ & العلاقات داخل العمل \\
\hline 0.69 & الدعم الاجتماعي \\
\hline 0678 & الحوافز المادية \\
\hline $0 ، 92$ & الدرجة الكلية \\
\hline
\end{tabular}

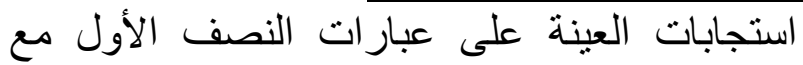

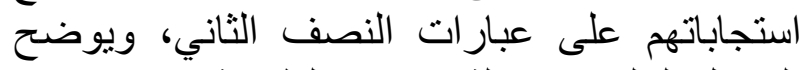
الجدول التالي نتائج الثبات بهذه الطريقة.
ب- طريقة التجزئة النصفية:

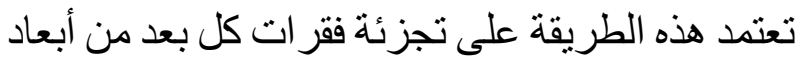

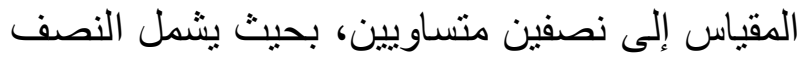

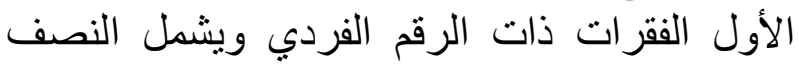

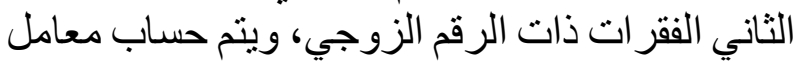

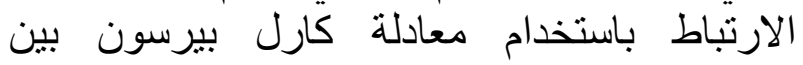

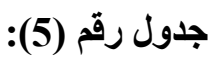

ثبات أبعاد مقياس الضغوط النفسية باستخدام طريقة التجزئة النصفية : 


\begin{tabular}{|c|c|c|c|}
\hline \multirow[b]{2}{*}{0674} & 6 & النصف الأول & \multirow[t]{2}{*}{ الانفعالات الناجمة من العمل } \\
\hline & 6 & النصف الثاني & \\
\hline \multirow[b]{2}{*}{$0 \cdot 66$} & 4 & النصف الأول & \multirow[t]{2}{*}{ بيئة العمل } \\
\hline & 4 & النصف الثاني & \\
\hline \multirow{2}{*}{$0 \cdot 76$} & 5 & النصف الأول & \multirow{2}{*}{ العلاقات داخل العمل } \\
\hline & 5 & النصف الثاني & \\
\hline \multirow[t]{2}{*}{0671} & 3 & النصف الأول & \multirow{2}{*}{ الدعم الاجتماعي } \\
\hline & 3 & النصف الثاني & \\
\hline \multirow[t]{2}{*}{0.79} & 2 & النصف الأول & \multirow{2}{*}{ الحوافز المادية } \\
\hline & 2 & النصف الثاني & \\
\hline
\end{tabular}

تم حساب معامل الثبات عن طريق معادلة الفا

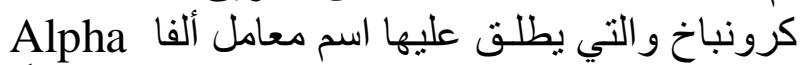
وذللك لكل أبعاد المقياس الخمســة و المقياس كاملاً. وقد قام الباحث بحساب معامل الثبات بهذه الطيان الطريقة

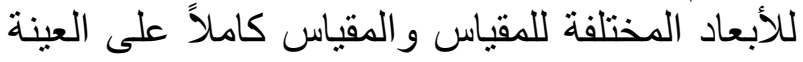

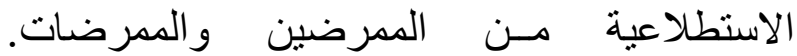

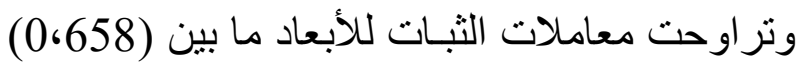
و (0،8931) بينما كان معامل الثبات للمقياس كله

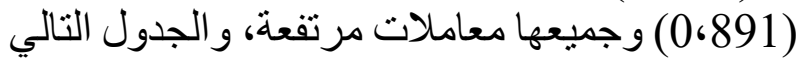
يوضح معاملات الثبات بهذه الطريقة.
وتوضح نتائج الجدول أعلاه ارتفاع معامل الارتباط

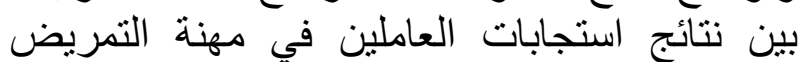
بمراكز الرعاية الأولية بمحافظة القويعية بالعينة الاستطلاعية على عبار ات النصف الأولة الأول مع نتائج

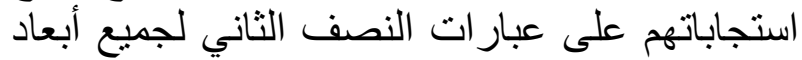

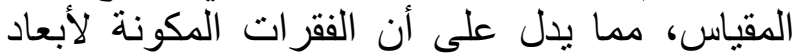

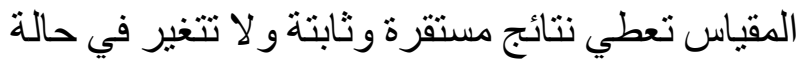
إعادة تطبيق المقياس مرة أخرى على العينة، وباته وبالتالي

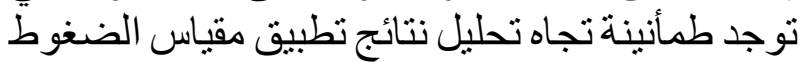

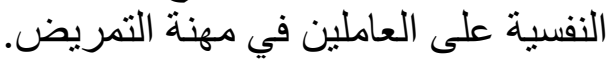

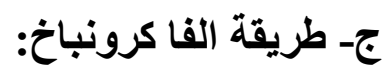

جدول رقم (6)

معاملات ثبات ألفا كرونباخ لأبعاد مقياس الضغوط الضغول

\begin{tabular}{|c|c|}
\hline معامل الثبات & أبعاد المقياس \\
\hline 0.823 & الاتفعالات الناجمة من العمل \\
\hline $0 \cdot 658$ & بيئة العمل \\
\hline $0 ، 877$ & العلاقات داخل العمل \\
\hline 06778 & الاعم الاجتماعي \\
\hline 0,931 & الحوافز المادية \\
\hline $0 ، 891$ & الارجة الكلية \\
\hline
\end{tabular}

ويتكون المقياس من (52) فكرة ، ويجيب عنها

المفحوص بنعم للالالة على قبوله للفكرة التي تقيسها
ثانياً: مقياس الأفكار العقلانية واللاعقلانية إعداد سليمان الريحاني (1985): 
اللاعقلانية لدى العاملين في مهنة التمريض بمر اكز الر عاية الأولية بمحافظة القويعية . 2- 2 - 20بات مقياس الأفكار اللاعقلانية: قام الباحث بحساب ثبات المقياس عن طريق معادلة الفا كرونباخ على العينة الاستطلاعية مسن الممرضين و الممرضات، وتراوحت معاملات الثبـات ما بين (06433) و (04840) بينما بلغت قيمة معامل الثبات

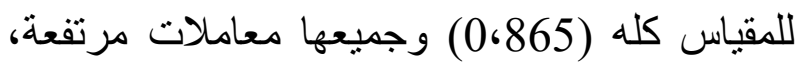
مما يدل على أن الفقرات المكونة لمقياس الأفكار

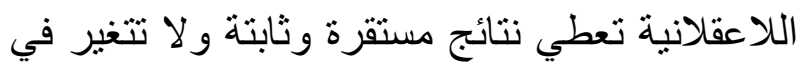
حالة إعادة تطبيق المقياس مرة أخرى على العينة، وبالتالي توجد طمأنينة تجاه تحليل نتائج تطبيق مقياس الفري الأفكار اللاعقلانية على العاملين في مهنة التمريض. نتائج الار اسلة: عرض وتحليل نتائج تساؤل الار اسة الأول:

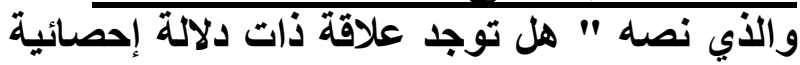

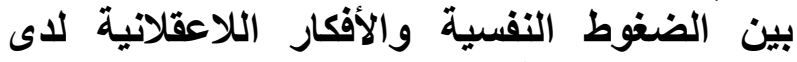
العاملين في مهنة التمريض في مستشفى ومراكز

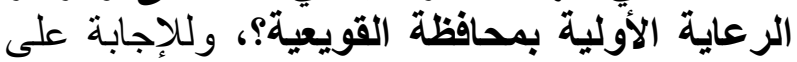

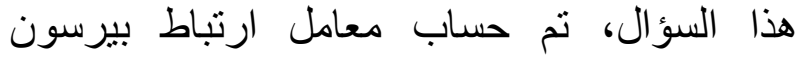

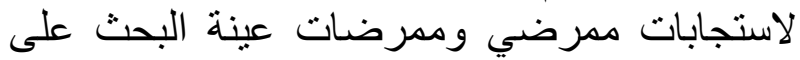
أبعاد مقياس الضغوط النفسية والأفكار اللاعقلانية، الإنة ويوضح الجدول التالي نتائج العلاقة الارنبارية الإعنانة ودلالتها الإحصائية.
العبارة ، وتأخذ الدرجة (2) ، أو يجيب بلا لبلل ذلك على رفض المفحوص للفكرة التي تقيسها العبارة ، وتأخذ الدرجة (1) وبذلك تتراوح الدرجة الكلية للمقياس ما بين ( 52 ) في حدها الأدنى، وهي تعبر عن رفض المفحوص لجميع الأفكار اللاعقلانية التي

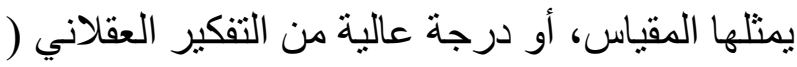

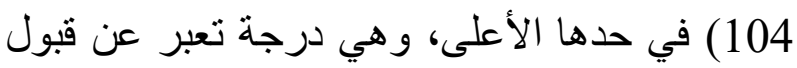

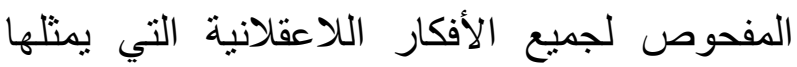
المقياس، أو عن درجة عالية من التفكير اللاعقلاني، لأل

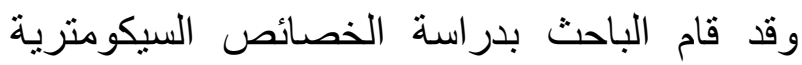

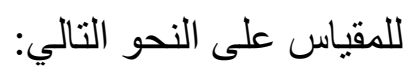
1 - صدق مقياس الأفكار اللاعقلانية : قام الباحث بتطبيق مقياس الأفكار اللاعقلانية على عينة إستطلاعية قو امها (100) من العاملين في مهنة التمريض بمستشفى القويعية العام، ومر اكز الرعاية الأولية بمحافظة القويعية ، وذللك للتعرف على صدق الاتساق الداخلي للمقياس من خلال ايجاد معاملات الارتباط بين الفقرة والدرجة الكلية للمقياس ، لاسل

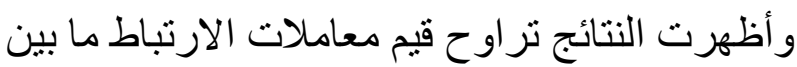
(0،45 ) و(0،69) وجميعها كانت موجبة ودالة

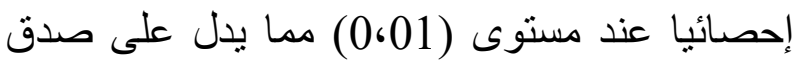
المحتوى و المضمون لفقرات مقياس الأفكار

\section{جدول رقم (9) )}

معاملات الارتباط ودلالتها بين أبعاد الضغوط النفسية والأفكار اللاعقلانية لممرضي العينة :

\begin{tabular}{|c|c|c|c|c|c|c|}
\hline للضغة الكلية & الحوافز & الاجتماعي & العلاقات داخل & بيئة العمل & الألعمة من & الضفسية \\
\hline$* * 0<18$ & $* * 0 ، 46$ & $* * 0<29$ & $* * 0<23$ & $* * 0$ *47 & $* * 0$ *36 & 1 \\
\hline$* * 0$ *26 & $* * 0,48$ & $* * 0 ، 35$ & $* * 0.37$ & $* * 0 \cdot 29$ & $* * 0 ، 41$ & 2 \\
\hline
\end{tabular}




\begin{tabular}{|c|c|c|c|c|c|c|}
\hline$* * 0$ *34 & $* * 0.37$ & $* 0.20$ & $* * 0 ; 29$ & $* * 0$. 33 & $* * 0.28$ & 3 \\
\hline$* * 0$ *27 & $* * 0$.50 & $* 0618$ & $* * 0636$ & $* * 0$ *46 & $* * 0639$ & 4 \\
\hline$* * 0,18$ & $* * 0$ *38 & $* * 0630$ & $* * 0 ، 41$ & $* * 0$ *36 & $* * 0$ (41 & 5 \\
\hline$* * 0,28$ & $* * 0,23$ & $* 0,21$ & $* * 0,43$ & $* * 0,47$ & $* * 0,29$ & 6 \\
\hline$* * 0,34$ & $* * 0,41$ & $* 0,26$ & $* * 0,49$ & $* * 0,29$ & $* * 0,51$ & 7 \\
\hline$* * 0,19$ & $* * 0,32$ & $* * 0,31$ & $* * 0,30$ & $* * 0,44$ & $* * 0,38$ & 8 \\
\hline$* * 0,21$ & $* * 0,39$ & $* * 0,30$ & $* * 0,28$ & $* * 0,38$ & $* * 0,27$ & 9 \\
\hline$* * 0,25$ & $* * 0,52$ & $* 0,27$ & $* * 0,24$ & $* * 0,29$ & $* * 0,40$ & 10 \\
\hline$* * 0,31$ & $* * 0,45$ & $* 0,18$ & $* * 0,37$ & $* * 0,32$ & $* * 0,26$ & 11 \\
\hline$* * 0 \cdot 22$ & $* * 0$ *38 & $* 0.23$ & $* * 0 ، 40$ & $* * 0,50$ & $* * 0.35$ & 12 \\
\hline$* * 0,30$ & $* * 0,23$ & $* 0,17$ & $* * 0,37$ & $* * 0,31$ & $* * 0,43$ & 13 \\
\hline$* * 0,26$ & $* * 0,51$ & $* * 0,23$ & $* * 0,38$ & $* * 0,49$ & $* * 0,36$ & الدرجة الكلية \\
\hline
\end{tabular}

، * دلالة إحصائية عند مستوى (0,05)

** دلالة إحصائية عند مستوى الالالة (0,01)

نظريته بأن الضغوط النفسية تحدث بسبب التفكير

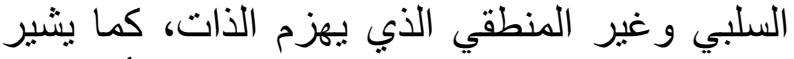

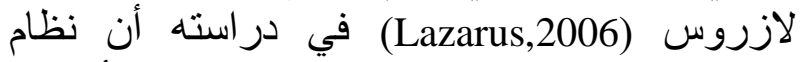

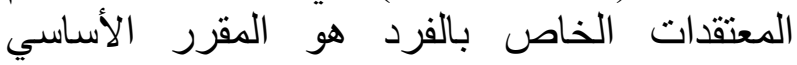

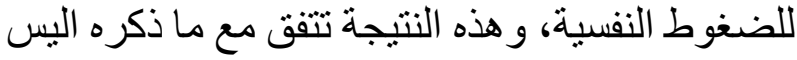
(Ellis, 1990) تعلمه يضطرب سلوكه، ولاى مقارنة نتيجة هذه

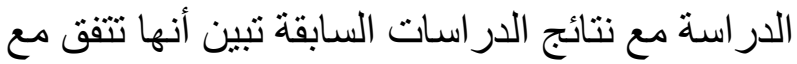

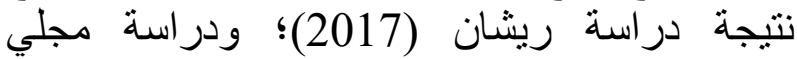

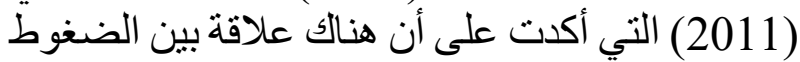
النفسية والأفكار اللاعقلانية، وخلال التل مر اجعة الباحث للار اسات السابقة حول الضغوط الإن النفسية و علاقتها بالأفكار اللاعقلانية لم يجد الباحث در اسة تخالف هذه النتيجة.

عرض وتحليل نتائج تساؤل الدراسة الثانى:

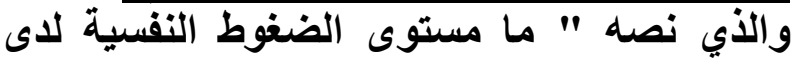
العاملين في مهنة التمريض في مستشئشفى ومراكز

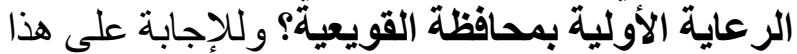

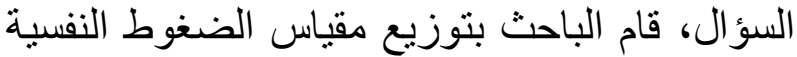

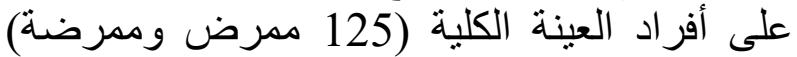
وحصلنا على النتائج الموضحة في الجدول الآتي:
وتوضح نتائج الجدول أعلاه أن معاملات الارتباط بين

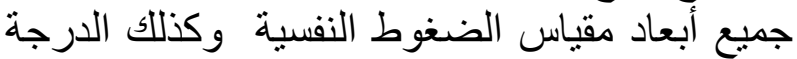
الكلية للضغوط وجميع الأفكار اللاعقلانية و الدرجة مفاد

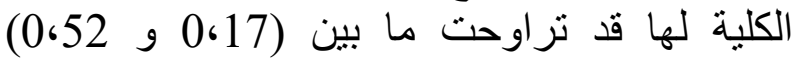
وجميعها معاملات ارتباط دالة إحصائيا عند مستوى

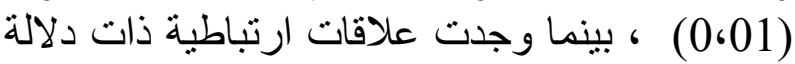

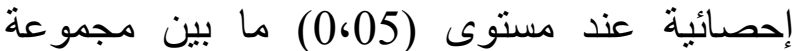

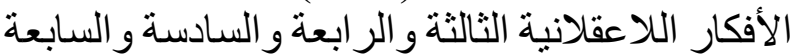
و العاثرة و الحادية عشر والثانية عشر والثالثة عشر الثانية

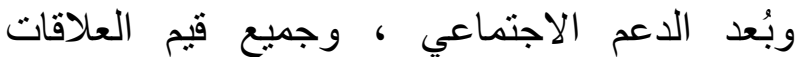

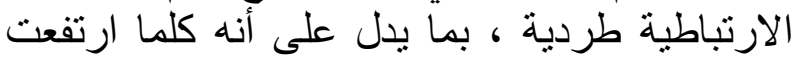

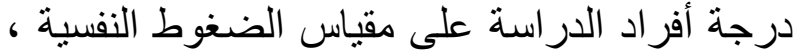

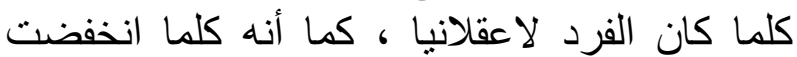

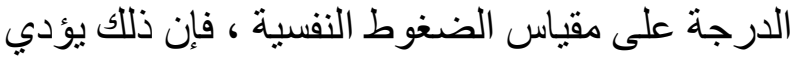

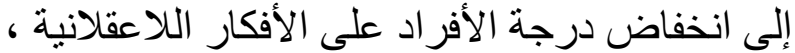
وذلك يثير إلى أنهم عقلانبين. و عند مناقثة النتيجة: يعزو الباحث هذه النتيجة إلى فئي

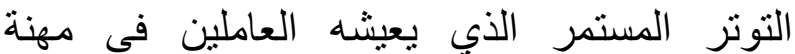
التمريض بسبب الحالات المرضية الخطرة، والتي لئي التئي تتسبب في التشوه المعرفي و التفكير الغير عقلاني لدى

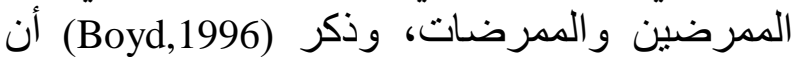

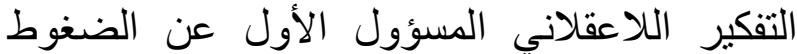
النفية لدى العاملين في المجال الصحير، وذكر الصري (Marie,2007) حدوث الأفكار الغير عقلانية، وقد أكد اليس Ellis في 


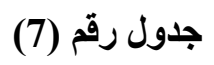

مستوى الضغوط النفسية لاى ممرضي العينة الكلية

\begin{tabular}{|c|c|c|c|}
\hline النسبة & 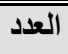 & مستويات الضغوط & 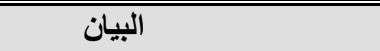 \\
\hline$\% 24$ & 30 & نادرا (44 -33،33 ) & \multirow{3}{*}{ الانفعالات الناجمة من العمل } \\
\hline$\% 26.4$ & 33 & أحيانا (67،102-33،73) & \\
\hline$\% 49 ، 6$ & 62 & غالبا (132-67،102) & \\
\hline$\% 31 \cdot 2$ & 39 & نادرا (44 -73،33 ) & \multirow{3}{*}{ بيئة العمل } \\
\hline$\% 28$ & 35 & أحياتا (67،102-33،73) & \\
\hline$\% 40.8$ & 51 & غالبا (132-67،102) & \\
\hline$\% 48 ، 8$ & 61 & نادرا (44 -73،33 ) & \multirow{3}{*}{ العلاقات داخل العمل } \\
\hline$\% 36$ & 45 & أحيانا (67،102-33،73) & \\
\hline$\% 15 \cdot 2$ & 19 & غالبا (132-67،102) & \\
\hline$\% 57.6$ & 72 & نادرا (44 -73،33 ) & \multirow{3}{*}{ الدعم الاجتماعي } \\
\hline$\% 28 ، 8$ & 36 & أحيانا (67،102-33،73) & \\
\hline$\% 13 ، 6$ & 17 & غالبا (132-67،102) & \\
\hline$\% 41 ، 6$ & 52 & نـادرا (44 -33،33 ) & \multirow[t]{3}{*}{ الحوافز المادية } \\
\hline$\% 20$ & 25 & أحيانا (67،102-33،73) & \\
\hline$\% 38 ، 4$ & 48 & غالبا (132-67،102) & \\
\hline$\% 32.8$ & 41 & نادرا (44 -73،33 ) & \multirow{3}{*}{ الارجة الكلية لمقياس الضغوط } \\
\hline$\% 28$ & 35 & أحيانا (67،33-102،73) & \\
\hline$\% 3962$ & 49 & غالبا (132-67،102) & \\
\hline$\% 100$ & 125 & \multicolumn{2}{|c|}{ المجموع (132-44) } \\
\hline
\end{tabular}

وتوضح نتائج الجدول أعلاه طبقا للارجة الكلية لمقياس الضغوط تحقق الضغوط النفسية لدى العاملين

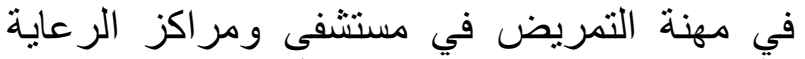

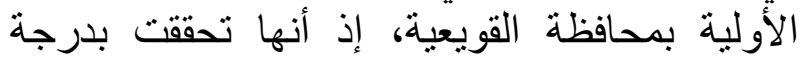
مرتفعة لدى (49 من عينة الدراسة) وبنسبة قدر هاتها

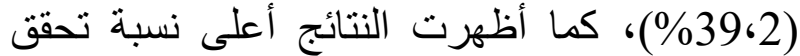

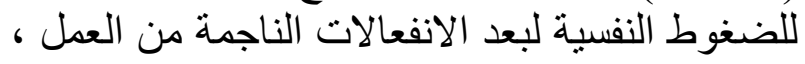

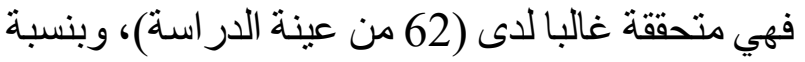
قدر ها (6\%، (49)، يلي ذلك في ترنيب تحقق الضغوط

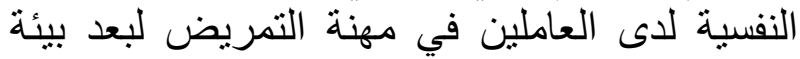

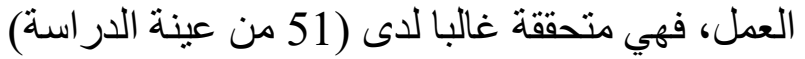
وبنسبة قدرها (8\%، (40)، ثم جاء في الترتيب الثالث
قام الباحث بتحديد مدى مقياس الضغوط النفسية و الذي

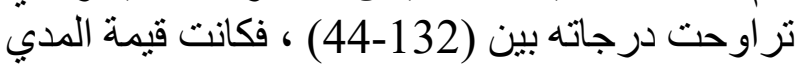

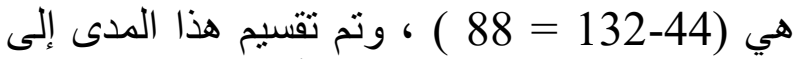

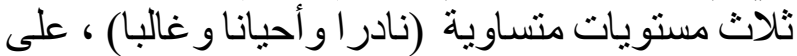
أن يكون مدى كل مستوى يساوي (29/88،33 = 29

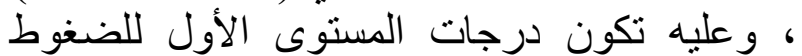
النفسية ( المنخفض أو نادرا) بين (44- 733، درجة، أما درجات المستوى الثاني للضغوط الضنات النفية

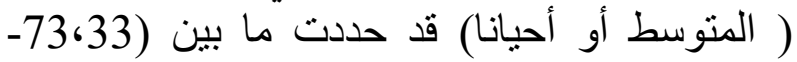

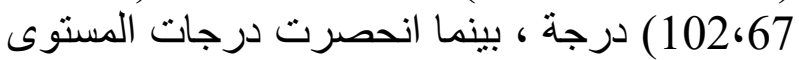
الثالث للضغوط النفسية ( المرتفع أو غالبا) ما بين (102،67 - 132) درجة. 
بمحافظة القويعية وخصوصاً العنصر النسائي، كذلك قلة توفر الإمكانيات و الخدمات المساندة لمهندة لمهنة التمريض وتتفق هذه النتيجة مع دراسة فيات فيابان (Fiaban,2012) مصادر الضغط النفسي والمهني لألى الثي المدرضين و الممرضات، كما شكل البعد الخامس الحو افز المادية

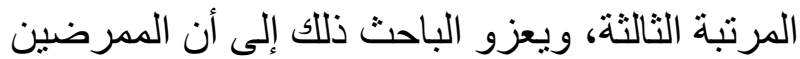

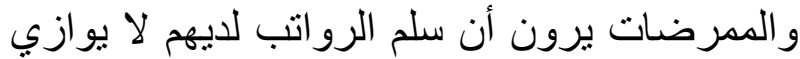

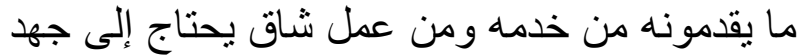

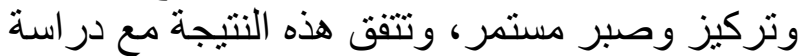

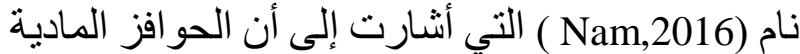

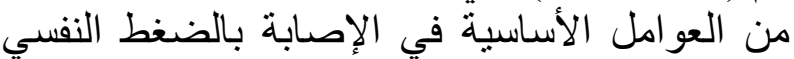

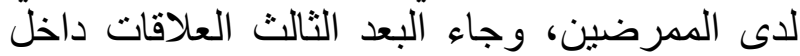

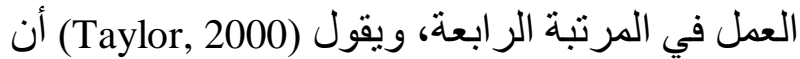
الممرضين مرتفعي الضغوط النفسية يميلون إلى بعلى

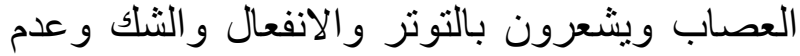

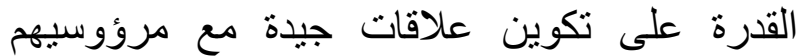

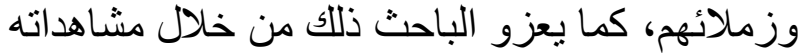

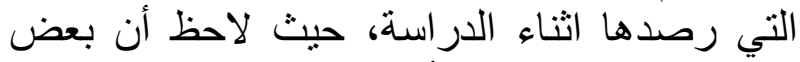

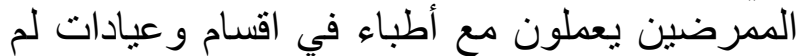
يحصلوا على تدريب وخبرات كافيه للعمل فيها،

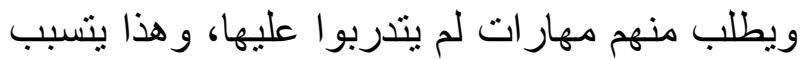

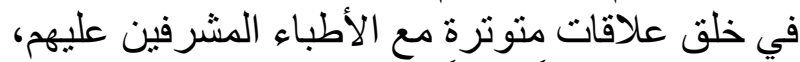

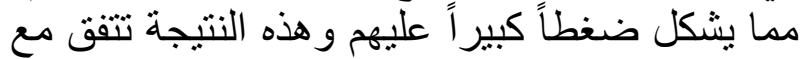

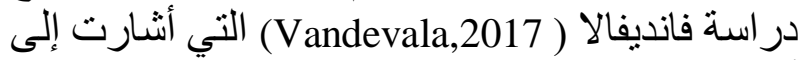

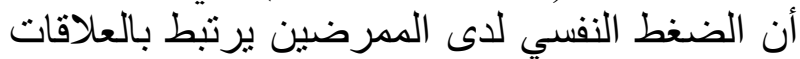

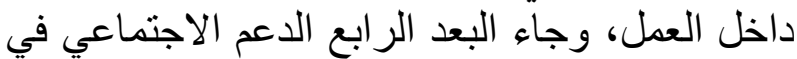

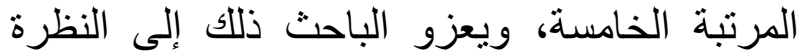

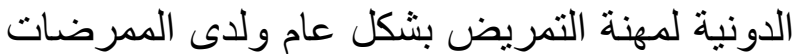

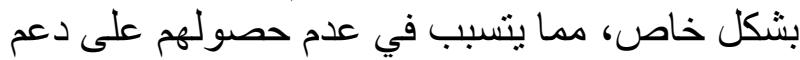
اجتماعي من أسرهم، فكثير من الثباب من أهالي

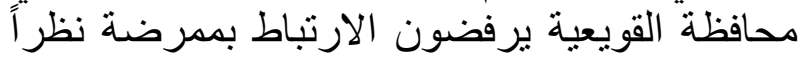
لعملها لساعات طويلة اثناء الليل، وهناء وهناك أخرين

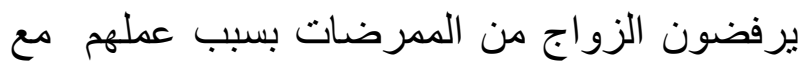

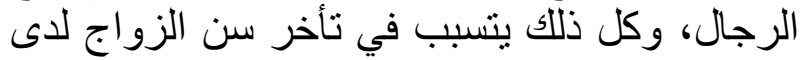

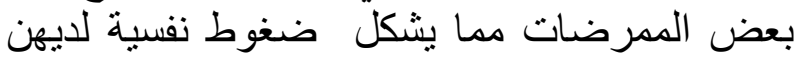
وتتفق هذه النتيجة مع در اسة وفاء الدعمس (2018)،
الضغوط النفسية الناجمة عن بعد الحوافز المادية، إذ تحققت غالبا لدى (48 من عينة الدراسة) وبنسبة

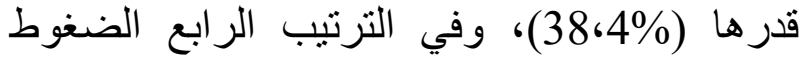
النفسية الناتجة عن بعد العلاقات داخل العمل ، فهي التهي

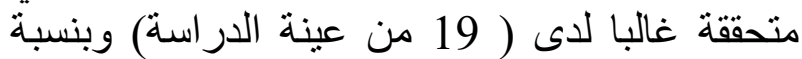

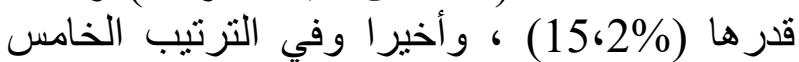

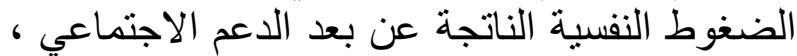

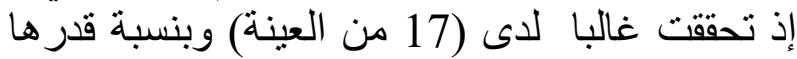
(\% 13،6) و عند مناقثة النتيجة بيضح أن الوزن النغي النسبي

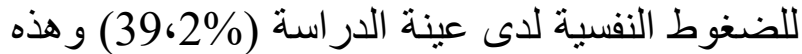
النتيجة تعكس ما بتعرض لله العاملين في مهنة

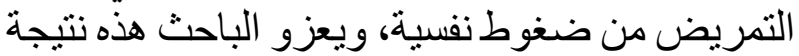

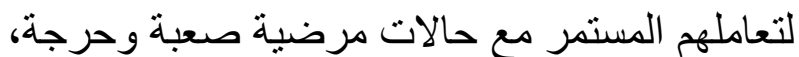

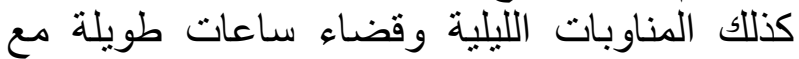
المرضى و غيابهم عن اسر هم ليلاً، كذلك يعزو الباحثي ذلك إلى تعامل العاملين في مهنة التمريض في في

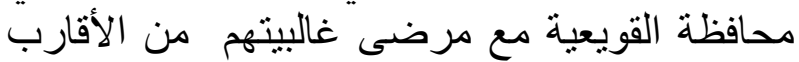

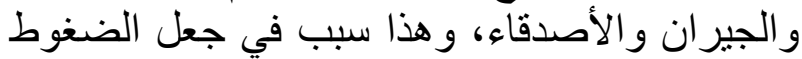
النفسية تحصل على هذا الوزن ، وتلتفق هذه النتيجة

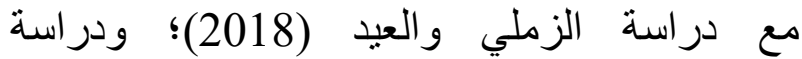
بورسيديجيان (Poursadeghiyan,2016).

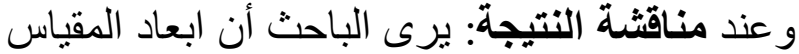

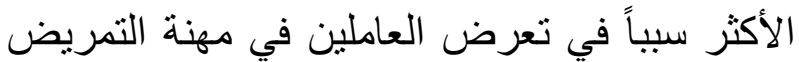

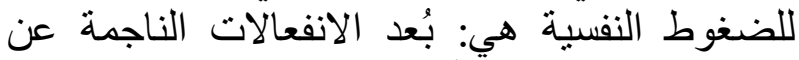

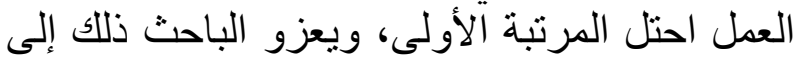
أن العاملين في مهنة التمريض في محافظة الوتلة القويعية

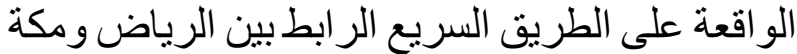

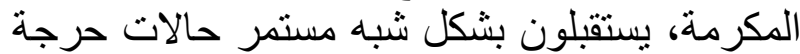

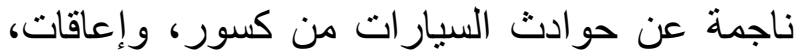
ووفيات، وهذا يجعل الممرضين و الممرضنات تحت

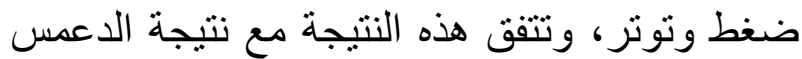

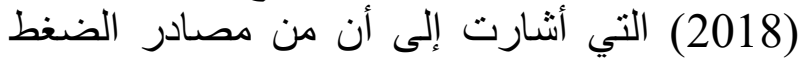

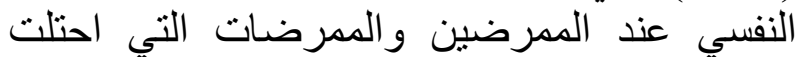

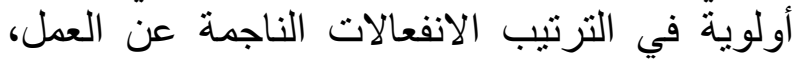

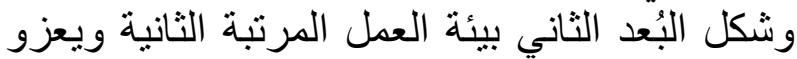

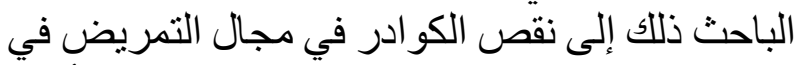
مستشفى القويعية العام ودراكز الرئ الرية الرية الأولية 
في مهنة التمريض) ، وتم حساب التكرار ات و النسبة

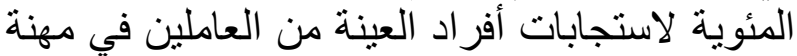

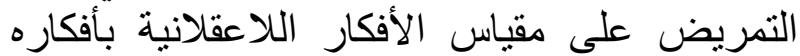

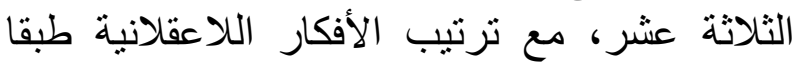

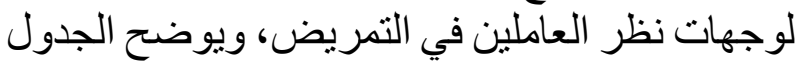
التالي النتائج المتحصل عليها:
التي أثنارت أن الممرضات لا يجدن الدعم الكافي من

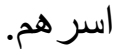
ورض وتصليل نتائج تساؤل الاراسة الثالث:

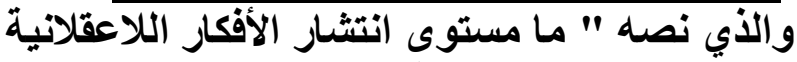

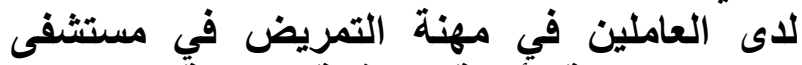

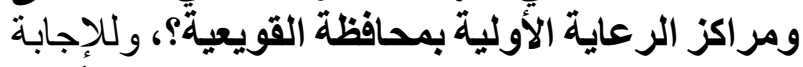

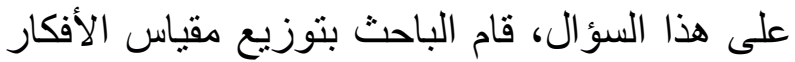
اللاعقلانية على أفر اد العينة الكلية (125 من العاملين

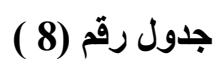

انتثار الأفكار اللاعقلانية لاى ممرضي العينة الكلية (125)

\begin{tabular}{|c|c|c|c|}
\hline الترتيب & 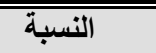 & 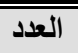 & الأفكار اللاعقلاتية \\
\hline 3 & $\% 38,4$ & 48 & طلب الاستحسان \\
\hline 10 & $\% 12,8$ & 16 & طلب الكمال الثخصي \\
\hline 7 & $\% 20,8$ & 26 & لوم الآخرين \\
\hline 8 & $\% 16$ & 20 & علدم التسامح تجاه الاحباطات \\
\hline 9 & $\% 14,4$ & 18 & تضخيم دور الظروف الخارجية \\
\hline 6 & $\% 30,4$ & 38 & توقع الكوارث \\
\hline 13 & $\% 7,2$ & 9 & تجنب الصعوبات \\
\hline 11 & $\% 11,2$ & 14 & الاعتمادية \\
\hline 12 & $\% 8,8$ & 11 & الاحسلس بالعزز تجاه الماضي \\
\hline 1 & $\% 48$ & 60 & الانز عاج لمشكلات الآخرين \\
\hline 2 & $\% 39,2$ & 49 & الحلول المثالية الكاملة \\
\hline 4 & $\% 36,8$ & 46 & الرسمية و الجدية \\
\hline 5 & $\% 32$ & 40 & تمييز الرجل \\
\hline & $\% 31,2$ & 39 & الارجة الكلية للمقياس \\
\hline
\end{tabular}

الثاني، إذ تحققت لدى (49 من عينة الدر اسة) وبنسبة قدرها (39،2 \% \% ) ) ، ويرى الباحث أن أن السبب في زيادة شيوع هذه الفكرة إنما يرجع إلى على عدم قدرة الني

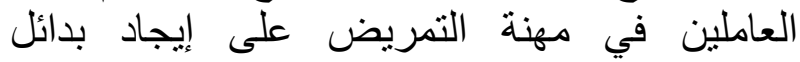

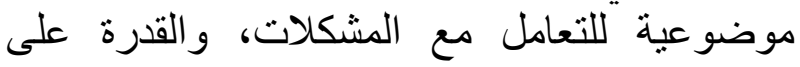

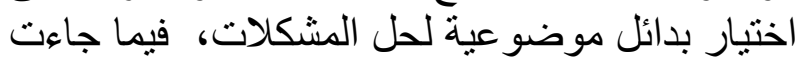

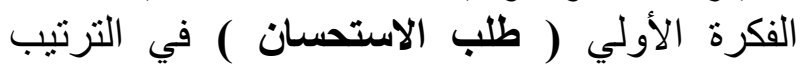

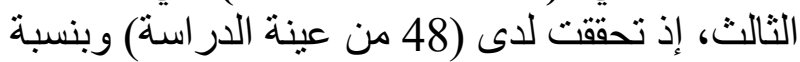
قدرها (38،4\%) ويعزو الباحث ذللك إلى التنشئة

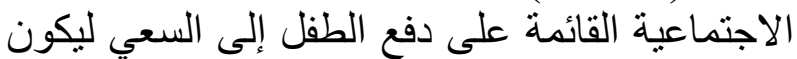
محبوباً ومرضياً عنه من قبل المحيطين بها، ومحاولة لالئل
وتوضح نتائج الجدول أعلاه، أن الفكرة العانشرة

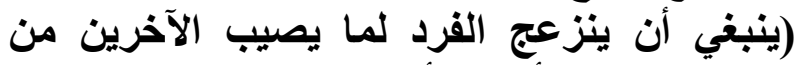

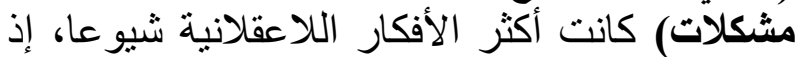

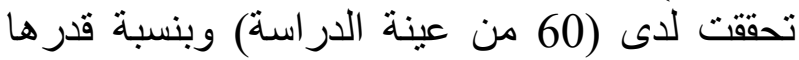

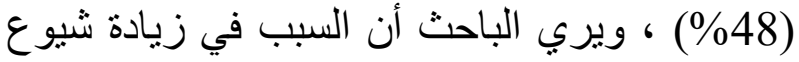

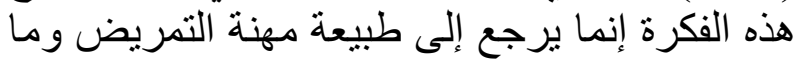

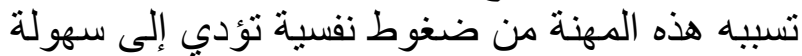
انزعاج الأفراد لما يصيب الآني الخرين من مشكلات

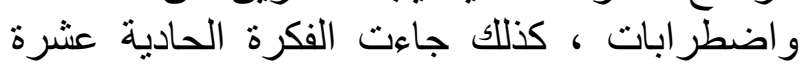

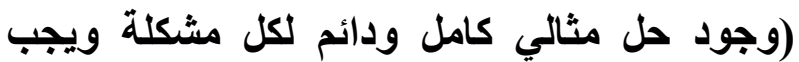
التوصل إليه و إلا ستكون النتائج خطيرة) في الترتيب 


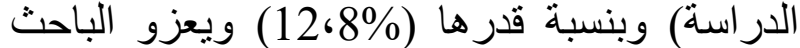
ذلك إلى التنشئة الو الدية القائمة على مطالبة الأبناء بأن

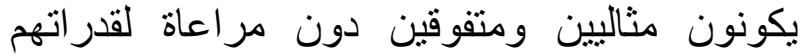

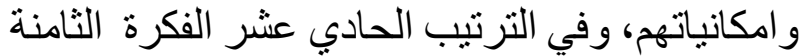

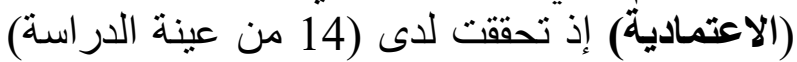

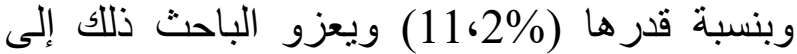

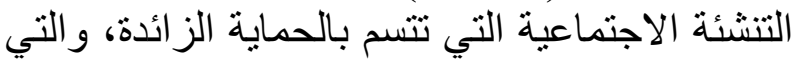

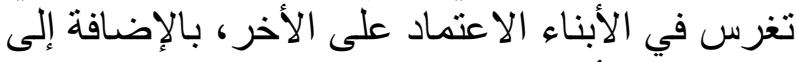

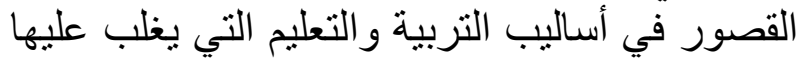

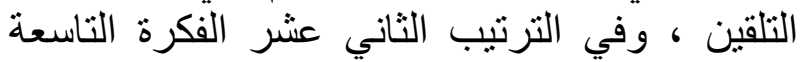

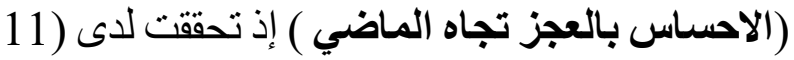

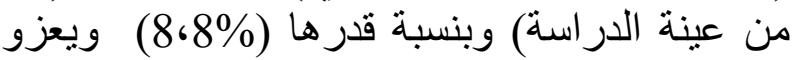
الباحث ذلك إلى التنشئة الاجتماعية القائمة على على

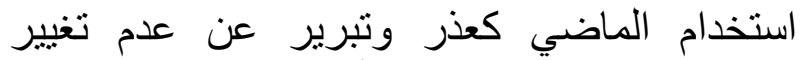
السلوك، ويفسر الباحث ذللك أيضا إلى الثقافة المحلية بالقويعية القائمة على الفخر بماضي الفي الأجداد و البكاء

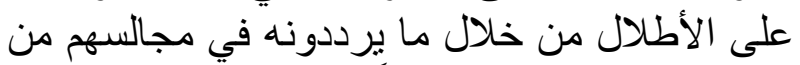

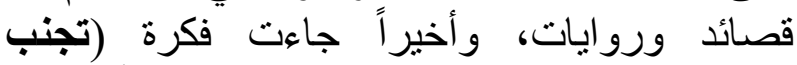
الصعوبات) في الترتيب الثالث عشر والأخير إذ إذات

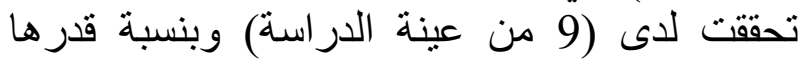

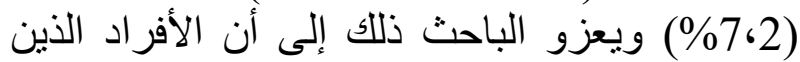

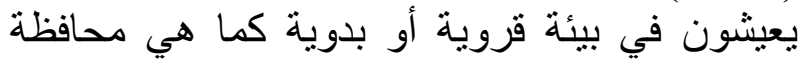
القويعية يتعودون على تحمل تلى المسؤولية في في سن مبكرة، ومن خلال الثقة و المسؤولية الممنوحة لهون لهم في في

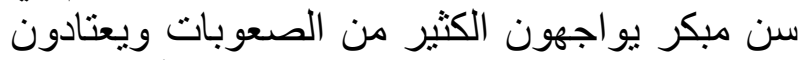
على مو اجهنها، لذلك جاءت الكئ في الترتيب الأخير.

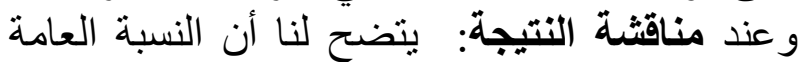
لانتشار الأفكار اللاعقلانية بلغت القيمة (20)، و وذه النتيجة تتفق مع ما أشتار إليه (Gurses, 2005)

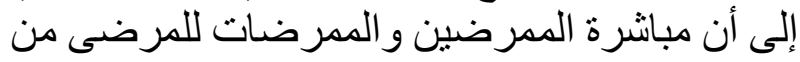

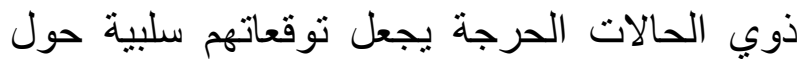
المستقبل مما يولد لديهم أفكار لا عقلانية، كما أثنار

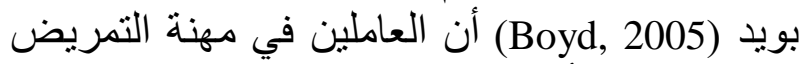

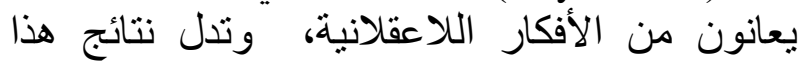

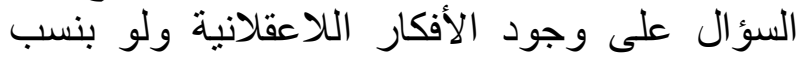

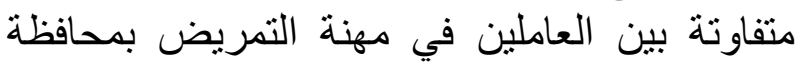

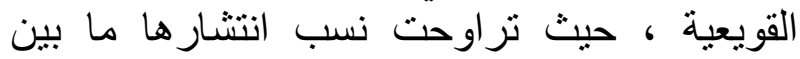
(\%72\%) في حدها الأنىى، و (48\% ) في حدها
إرضاء الاخرين بشتى الطرق، ثم في الترتيب الر ابع الترائ

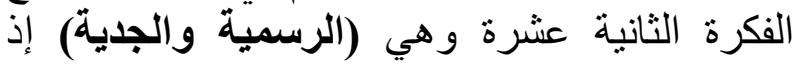

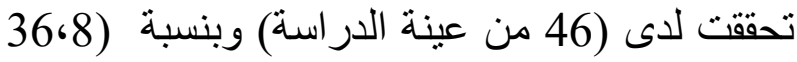
\%) ويعزو الباحث ذلإن إلى التعامل السطحي من

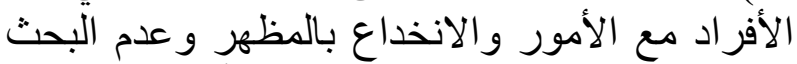

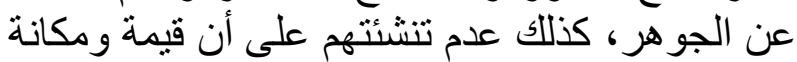

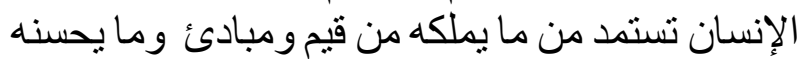

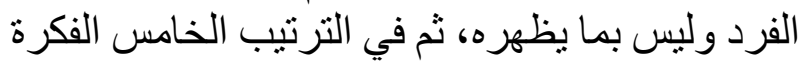

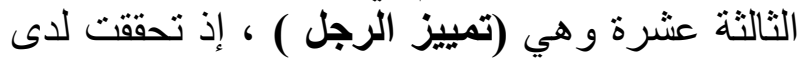

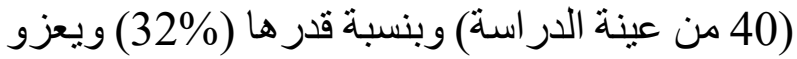
الباحث ذللك إلى الثقافة السعودية التي تؤكد على مكانة

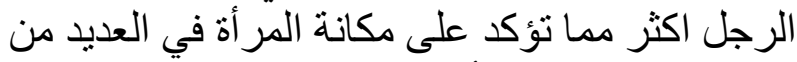

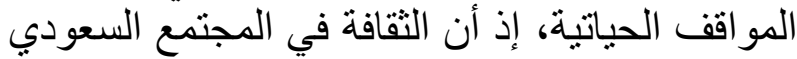
ثقافة ابوية تعطي الأب مكانه شبه مطلقة داخل البل البيت البيت،

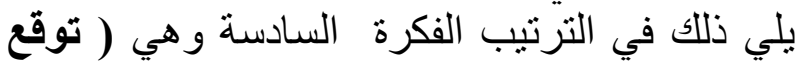

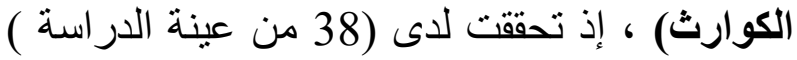

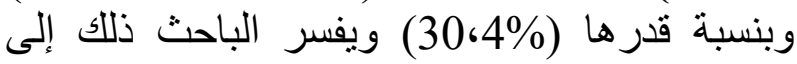
صعوبة الحالات التي يتعامل معها العاملين في مهنة التمريض في القويعية فأغلب الحالات التي يتعاملون

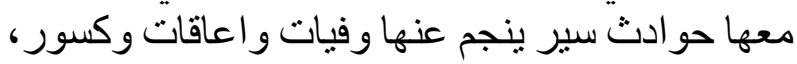
ثم في الترتيب السابع الفكرة الثالثة وهي(لوم التئ آلآخرين

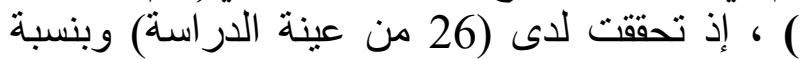

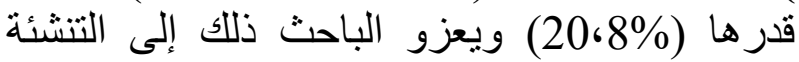
الاجتماعية في المجتمعات القروية والبدوية التي لإلية

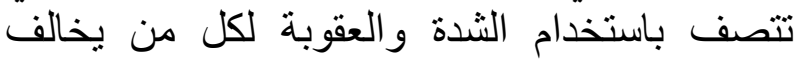

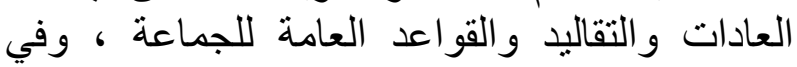
الترتيب الثامن الفكرة الرابعة (عدم التسامح تجاه التهاه

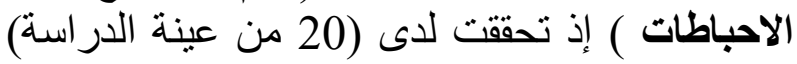

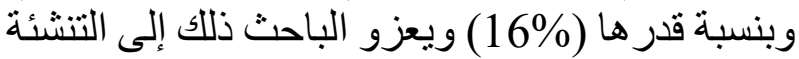

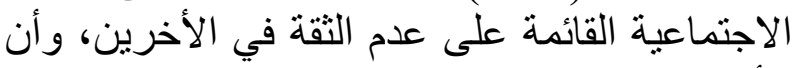

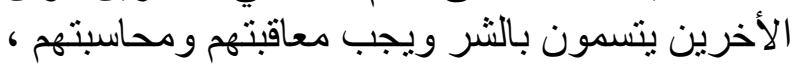
وفي الترتيب التاسع الفكرة الخامسة (تضخيم دور الظروف الخارجية ) إذ تحققت لاى (14.4) من الترة عينة

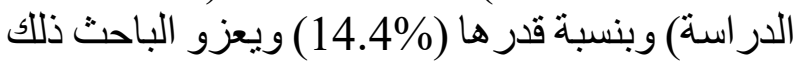
إلى التنشئة الو الدية القائمة على أن كثير من الأمور

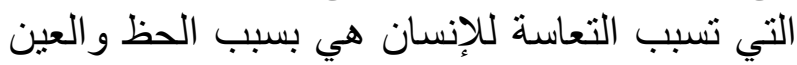

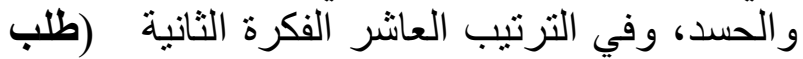
الكمال الثخصي) إذ تحققت لاى (16 من عينة 
والذي نصد " هل توجد فروق ذات دلالة إحصائية

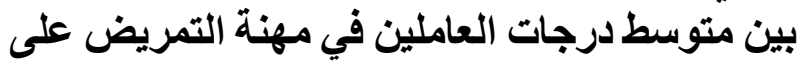

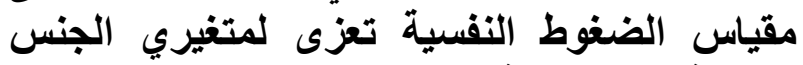

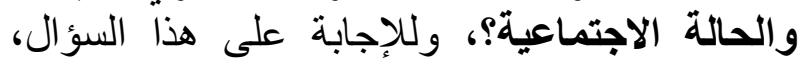

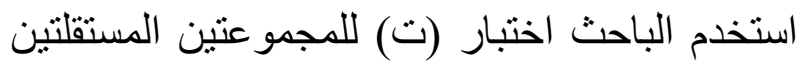

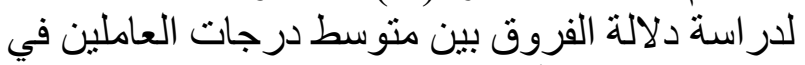

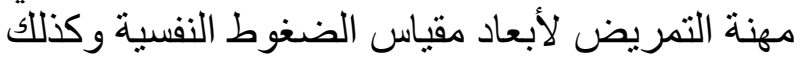
الدرجة الكلية للمقياس والتئي تلادي التعزي إلى متغيري

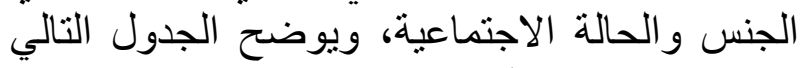
نتائج الاختبار ودلالته الإحصائية.
الأعلى، وتتفق هذه النتيجة مع نتيجة دراسة ريشان

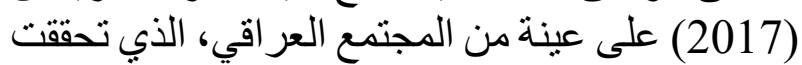

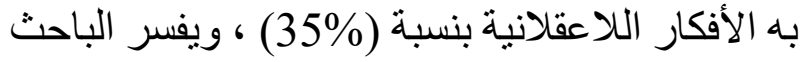

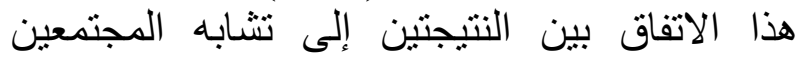

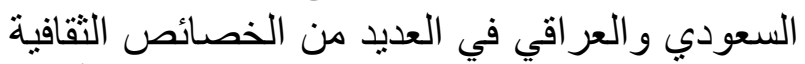

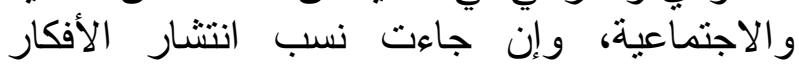
اللاعقلانية في المجتمع السعودي أقل منها عما في النياري المجتمع العر اقي. عرض وتحليل نتثائج تساوئل الار اسة الرابع:

جدول رقم (10)

دلالة الفروق بين العاملين في التمريض لمقياس الضغوط النفسية طبقا لمتغيري الجنس والحالة الاجتماعية :

\begin{tabular}{|c|c|c|c|c|c|c|}
\hline الدالة & قاقيمة (ت) & الالاتحراف & المتوسط & العدد & المجموعة & أبعاد الضغوط \\
\hline \multirow[t]{2}{*}{ غبر دالة } & \multirow[t]{2}{*}{3,65} & 1,11 & 56,2 & 72 & الممرضين & \multirow{4}{*}{ الانفعالات الناجمة } \\
\hline & & 1,16 & 54,7 & 53 & الممرضات & \\
\hline \multirow[t]{2}{*}{ دالة } & \multirow[t]{2}{*}{${ }^{*} 6,81$} & 1,04 & 65,9 & 71 & متزوجين & \\
\hline & & 1,21 & 57,1 & 54 & غير متزوجين & \\
\hline \multirow[t]{2}{*}{ دالة } & \multirow[t]{2}{*}{$* 6,04$} & 1,21 & 58,6 & 72 & الممرضين & \multirow{4}{*}{ بيئة العمل } \\
\hline & & 1,09 & 69,2 & 53 & الممرضات & \\
\hline \multirow[t]{2}{*}{ دالة } & \multirow[t]{2}{*}{$* 6,72$} & 1,04 & 71,2 & $\overline{71}$ & متزوجين & \\
\hline & & 1,18 & 59,8 & 54 & غير متزوجين & \\
\hline \multirow[t]{2}{*}{ دالة } & \multirow[t]{2}{*}{$* 5,99$} & 1,09 & 48,3 & 72 & الكمرضين & \multirow{4}{*}{ العلاقات داخل العمل } \\
\hline & & 1,01 & 63,7 & 53 & الممرضات & \\
\hline \multirow[t]{2}{*}{ غير دالة } & \multirow[t]{2}{*}{3,94} & 1,13 & 55,9 & 71 & متزوجين & \\
\hline & & 1,22 & 58,4 & 54 & غير متزوجين & \\
\hline \multirow[t]{2}{*}{ غير دالة } & \multirow[t]{2}{*}{3,62} & 1,17 & 51,7 & 72 & الممرضين & \multirow{4}{*}{ الدم الاجتماعي } \\
\hline & & 1,23 & 53,2 & 53 & الممرضات & \\
\hline \multirow[t]{2}{*}{ غير دالة } & \multirow[t]{2}{*}{3,26} & 1,20 & 60,4 & 71 & متزوجين & \\
\hline & & 1,25 & 58,5 & 54 & غير متزوجين & \\
\hline \multirow[t]{2}{*}{ دالة } & \multirow[t]{2}{*}{$* 5,90$} & 1,03 & 66,3 & 72 & الممرضين & \multirow{4}{*}{ الحوافز المادية } \\
\hline & & 1,22 & 49,5 & 53 & الممرضات & \\
\hline \multirow[t]{2}{*}{ دالة } & \multirow[t]{2}{*}{$* 6,48$} & 1,07 & 69,8 & 71 & متيزوجين & \\
\hline & & 1,15 & 55,3 & 54 & غير متزوجين & \\
\hline \multirow[t]{2}{*}{ دالة } & \multirow[t]{2}{*}{ *6,34 } & 1,11 & 54,9 & 72 & الممرضين & \multirow{3}{*}{ الارجة الكلية للضنوط النفسية } \\
\hline & & 1,08 & 65,4 & 53 & الممرضات & \\
\hline دالة & $* 7,14$ & 1,05 & 72,3 & 71 & متزوجين & \\
\hline
\end{tabular}




\section{\begin{tabular}{|l|l|l|l|r|}
\hline & & 1,92 & 57,6 & 5 \\
\hline
\end{tabular}}

يتطلب جه كبير ومناوبة ليلية في بعض الأسابيع،

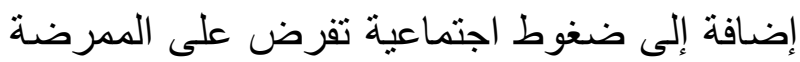

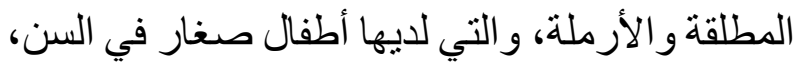

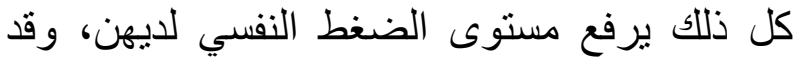

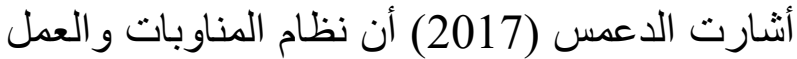
الليلي يعتبر من مصادر الضغط النفسي التي احتلت أولوية الترتيب لدى الممرضات، ويخلص مذه الباحث من هذه النتائج إلى أن متغير الجنس يؤثر في استجابات

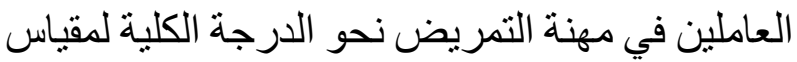
الضغوط النفسية و أبعاد بيئة العمل و العلاقات داخل فئل

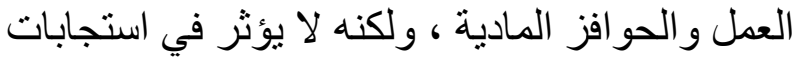

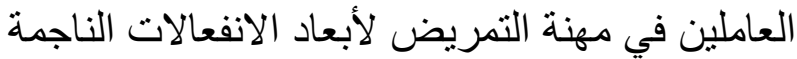

$$
\text { من العمل و الدعم الاجتماعي. }
$$

ثانيا: بالنسبة لمتغير الحالة الاجتماعية ، الأية ، أوضحت

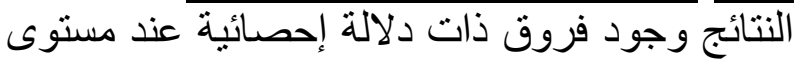

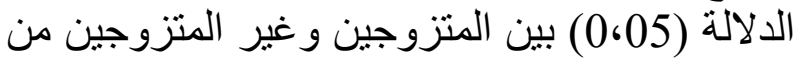
العاملين بمهنة التمريض في مستشفى ومر اكز الرينة الرعاية الأولية بمحافظة القويعية في الدرجة الكية فيلية لمقياس

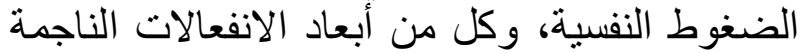

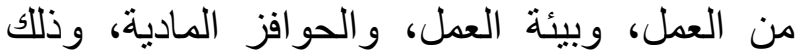
لصالح المتزوجين، ويتضح ذللك من الفرق الواضح في قيم المتوسطات الحسابية لدرجات المنات المنزوجين

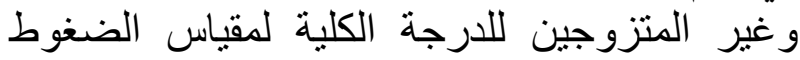
النفسية، و أبعاد الانفعالات الناجمة من العمل وبيئة

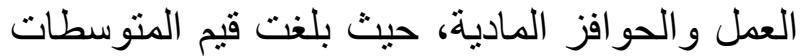
الحسابية لاستجابات المتزوجين للارجة الفية الكلية

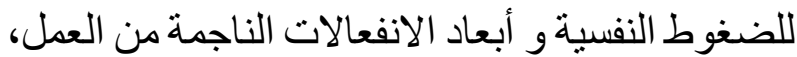

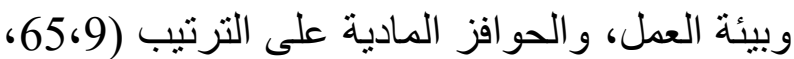

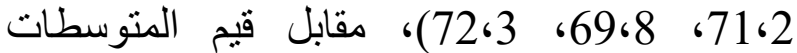

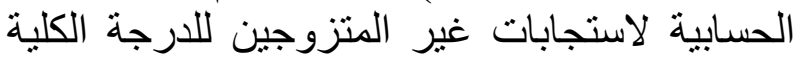
للضغوط النفسية وأبعاد الانفعالات الناجمة من العمل، العابك،

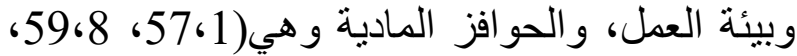

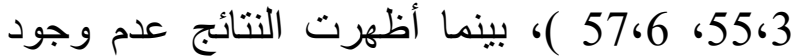
فروق ذات دلالة إحصائية بين قيم المتوسطات
54

\section{غير متزوجين}

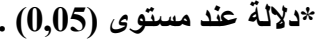

وتوضح نتائج الجدول أعلاه ما يلي:

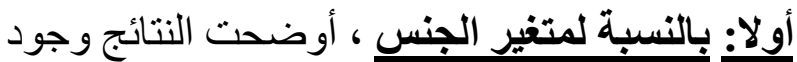
فروق ذات دلالة إحصائية عند مستوى الدلالة (05،05) بين الممرضين و الممرضات في مستشفى ومر اكز الرعاية الأولية بمحافظة القويعية في الدرجة الكلية

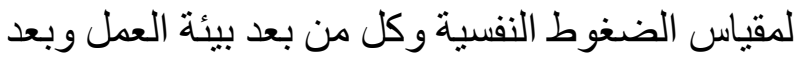

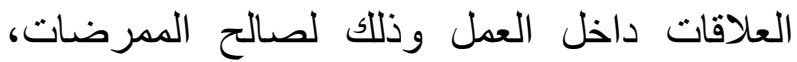
ويتضح ذللك من الفرق الواضح في قيم المتوسطات

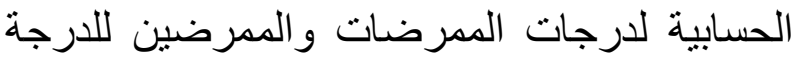
الكلية لمقياس الضغوط النفسية ، وبعدي بيئة العمل ولهئ و العلاقات داخل العمل، حيث بلغت قيم المتوسطات

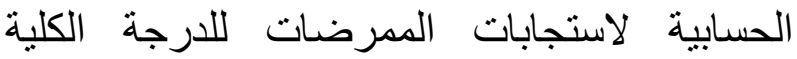
للضغوط النفسية، وبعدى بيئة العمل و العلاقات داخل

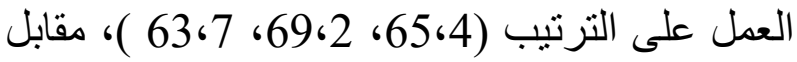
قيم المتوسطات الحسابية لاستجابات المدرضين للارجة الكلية للضغوط النفسية وبعدى بيئة العمل

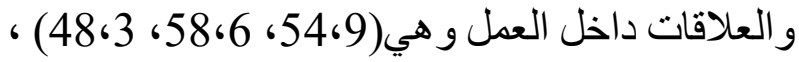
كذلك أوضحت النتائج أيضا وجود فروق ذات اته دلاتلة

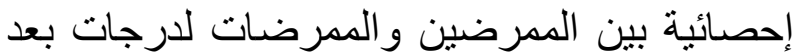
الحو افز المادية ولصالح الممرضين بلين ، حيث بلغت قيمة

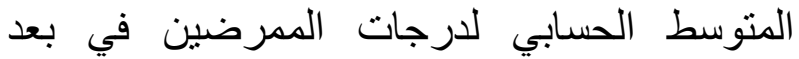
الحو افز القيمة (66،63) مقابل متوسط حسابي لدرجات

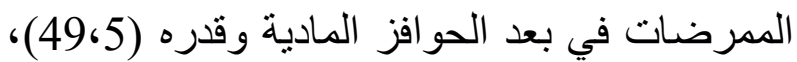

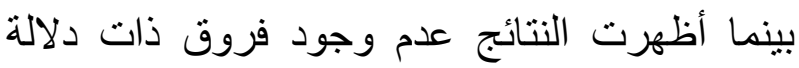
إحصائية بين قيم المتوسطات الحسابية لدرجات الممرضين و الممرضات في أبعاد الانفعالات الناجمة من العمل و الدعم الاجتماعي.

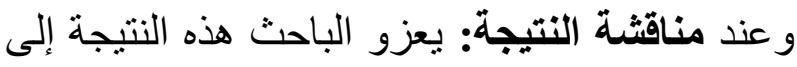

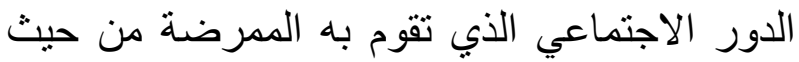

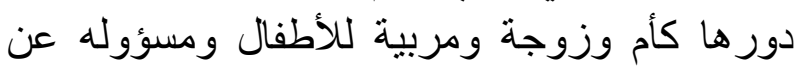
الكثير من شؤون المنزل، إضافة إلى عملى وملها الذي ولي 
أطفالهم، ولم تتفق هذه النتيجة مع دراسة صبيرة

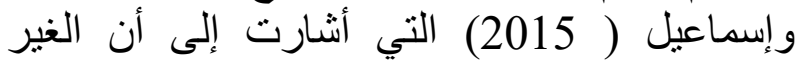

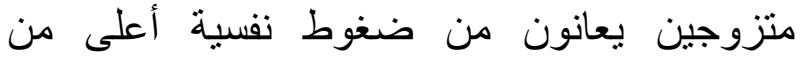

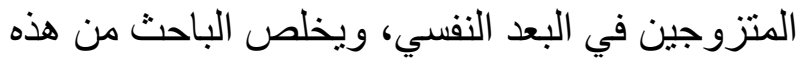

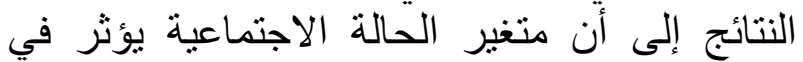
استجابات العاملين في مهنة التمريض نحو الدرجة الدانة

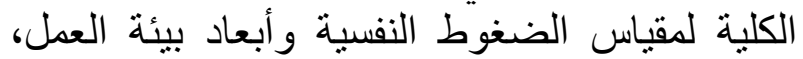

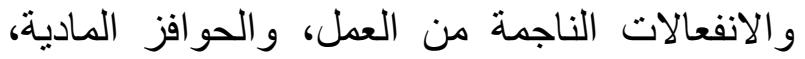
ولكنه لا يؤثر في استجابات العاملين في مهنة الاتهية

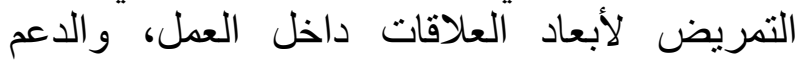
الاجتماعي. عرض وتحليل نتائج تساؤل الدراسة الخامس:

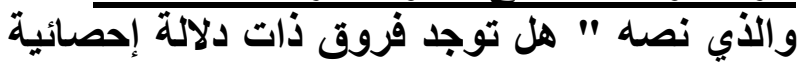

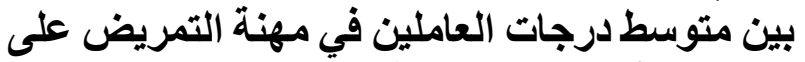

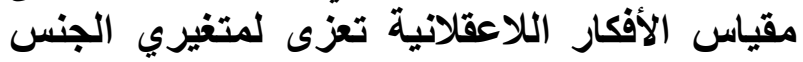

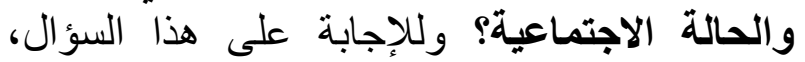

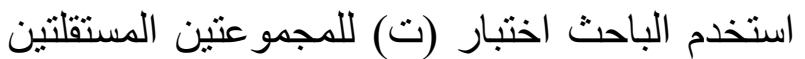
لدر اسة دلالة الفروق بين متوسط درجات التهات العاملين في

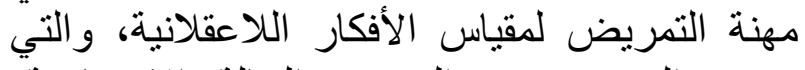
تعزي إلى متغيري الجنس والحالة الاجتماعية، ويوضتح الجدول التنالي نتائج الاختبار ودلالته الإحصائية.
الحسابية لدرجات المتزوجين وغير المتزوجين في

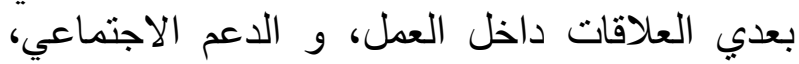

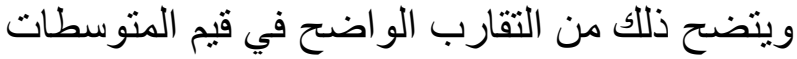

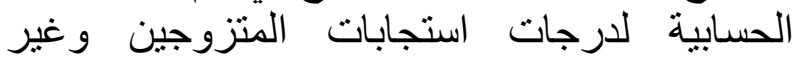

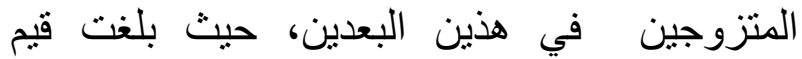

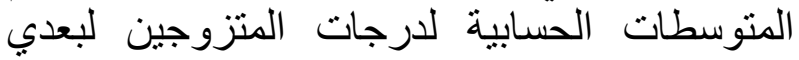
العلاقات داخل العمل، و الدعم الاجتماعي القيم (60، ، 60،4) على الترتيب مقابل قيم المتوسطات الحسابية

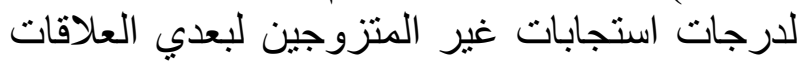

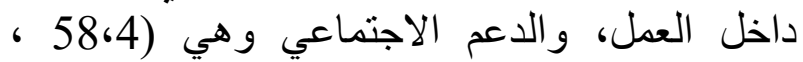

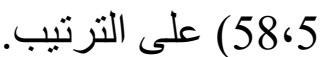

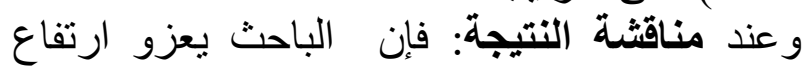
الضغوط النفسية لدى المتزوجين من العاملين في مهنة

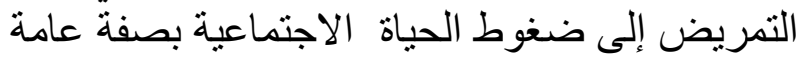
ومتطلبات ومسئوليات الحياة الأسرية بصفة خاصة الأهة

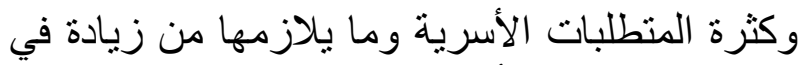

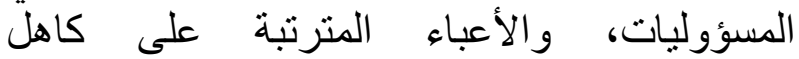
المتزوجين، كما أبدت هذه الاءتاء النتيجة دراسة وفاء

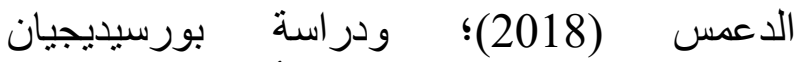
Huey, (Poursadeghiyan, 2016)، وقد أشنار هيونة (2018)

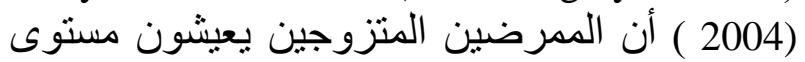
عالي من الضغوط النفية بسبب التفكير الزائد في مئي توفير مسكن مناسب للأسرة، ومدارس جيدة لتعليم

جدول رقم (11)

دلالة الفروق بين العاملين في التمريض لمقياس الأفكار اللاعقلالية طبقا لمتغيري الجنس والحالة الاجتماعية:

\begin{tabular}{|c|c|c|c|c|c|c|}
\hline الدلالة & قيمة (ت) & الانحراف & المتوسط & العدد ال الع & المجموعة & الأفكار \\
\hline \multirow[t]{2}{*}{ دالة } & \multirow[t]{2}{*}{$* 7,01$} & 1,01 & 71,2 & 72 & الممرضين & \multirow{4}{*}{ الاستحسان } \\
\hline & & 1,12 & 60,3 & 53 & الممرضات & \\
\hline \multirow[t]{2}{*}{ دالة } & \multirow[t]{2}{*}{$* 6,18$} & 1,15 & 61,5 & 71 & متزوجين & \\
\hline & & 1,04 & 76,4 & 54 & غير متزوجين & \\
\hline \multirow[t]{2}{*}{ غير دالة } & \multirow[t]{2}{*}{2,88} & 1,14 & 53,9 & 72 & الممرضين & \multirow{4}{*}{ الثخصي } \\
\hline & & 1,19 & 56,7 & 53 & الممرضـات & \\
\hline \multirow[t]{2}{*}{ غير دالة } & \multirow[t]{2}{*}{3,74} & 1,18 & 59,1 & 71 & متزوجين & \\
\hline & & 1,22 & 54,8 & 54 & غير منزوجين & \\
\hline \multirow[t]{2}{*}{ غير دالة } & \multirow[t]{2}{*}{4,04} & 1,19 & 59,2 & 72 & الممرضين & \multirow[t]{4}{*}{ لوم الآخرين } \\
\hline & & 1,25 & 56,6 & 53 & الممرضـات & \\
\hline \multirow[t]{2}{*}{ غير دالة } & \multirow[t]{2}{*}{4,31} & 1,10 & 58,1 & 71 & متزوجين & \\
\hline & & 1,16 & 54,9 & 54 & غير منزوجين & \\
\hline
\end{tabular}




\begin{tabular}{|c|c|c|c|c|c|c|}
\hline \multirow[t]{2}{*}{ غير دالة } & \multirow[t]{2}{*}{3,76} & 1,17 & 58,8 & 72 & الممرضين & \multirow{4}{*}{ عدم التسامع } \\
\hline & & 1,13 & 52,6 & 53 & الممرضـات & \\
\hline \multirow[t]{2}{*}{ غير دالة } & \multirow[t]{2}{*}{4,19} & 1,19 & 51,7 & 71 & متزوجين & \\
\hline & & 1,23 & 53,2 & 54 & غير متزوجين & \\
\hline
\end{tabular}




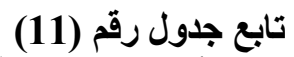

دلالة الفروق بين العاملين في التمريض لمقياس الأفكار اللاعقلانية طبقا لمتغيري الجنس والحالة الاجتماعية:

\begin{tabular}{|c|c|c|c|c|c|c|}
\hline الدلالة & قيمة(ت) & الانحراف & المتوسط & العدد | ل العد & المجموعة & الأفكار \\
\hline \multirow[t]{2}{*}{ غير دالة } & \multirow[t]{2}{*}{3,64} & 1,14 & 60,2 & 72 & الممرضين & \multirow{4}{*}{ تضخيم دور } \\
\hline & & 1,20 & 59,9 & 53 & الممرضـات & \\
\hline \multirow[t]{2}{*}{ غير دالة } & \multirow[t]{2}{*}{3,55} & 1,21 & 55,5 & 71 & متزوجين & \\
\hline & & 1,26 & 50,6 & 54 & غير متزوجين & \\
\hline \multirow[t]{2}{*}{ دالة } & \multirow[t]{2}{*}{$* 6,33$} & 1,09 & 73,7 & 72 & الممرضين & \multirow[t]{4}{*}{ توقع الكوارث } \\
\hline & & 1,18 & 59,8 & 53 & الممرضات & \\
\hline \multirow[t]{2}{*}{ دالة } & \multirow[t]{2}{*}{$* 6,05$} & 1,14 & 60,6 & 71 & متزوجين & \\
\hline & & 1,06 & 76,3 & 54 & غير منزوجين & \\
\hline \multirow[t]{2}{*}{ غير دالة } & \multirow[t]{2}{*}{3,71} & 1,23 & 54,4 & 72 & الممرضين & \multirow{4}{*}{ الصعوبات } \\
\hline & & 1,14 & 57,8 & 53 & الممرضات & \\
\hline \multirow[t]{2}{*}{ غير دالة } & \multirow[t]{2}{*}{3,14} & 1,19 & 56,3 & 71 & متزوجين & \\
\hline & & 1,13 & 54,8 & 54 & غير متزوجين & \\
\hline \multirow[t]{2}{*}{ غير دالة } & \multirow[t]{2}{*}{3,81} & 1,10 & 61,7 & 72 & الممرضين & \multirow[t]{4}{*}{ الاعتمادية } \\
\hline & & 1,13 & 63,1 & 53 & الممرضات & \\
\hline \multirow[t]{2}{*}{ غير دالة } & \multirow[t]{2}{*}{3,66} & 1,07 & 58,5 & 71 & متزوجين & \\
\hline & & 1,03 & 56,8 & 54 & غير متزوجين & \\
\hline \multirow[t]{2}{*}{ غير دالة } & \multirow[t]{2}{*}{4,11} & 1,17 & 51,6 & 72 & الممرضين & \multirow{4}{*}{ بالعجز تجاه } \\
\hline & & 1,23 & 54,3 & 53 & الممرضنات & \\
\hline \multirow[t]{2}{*}{ غير دالة } & \multirow[t]{2}{*}{3,62} & 1,13 & 56,9 & 71 & متزوجين & \\
\hline & & 1,20 & 59,8 & 54 & غير متزوجين & \\
\hline \multirow[t]{2}{*}{ دالة } & \multirow[t]{2}{*}{$* 6,63$} & 1,09 & 73,5 & 72 & الممرضين & \multirow{4}{*}{ الآشكلات الآخرين } \\
\hline & & 1,22 & 62,8 & 53 & الممرضات & \\
\hline \multirow[t]{2}{*}{ دالة } & \multirow[t]{2}{*}{$* 6,92$} & 1,15 & 61,7 & 71 & متزوجين & \\
\hline & & 1,09 & 77,6 & 54 & غير متزوجين & \\
\hline \multirow[t]{2}{*}{ دالة } & $* 5,98$ & 1,03 & 70,9 & 72 & الممرضين & الحلول المثالية \\
\hline & & 1,18 & 64,8 & 53 & الممرضات & الكاملة \\
\hline دالة & $* 6,72$ & 1,16 & 59,6 & 71 & متزوجين & \\
\hline & & 1,01 & 75,3 & 54 & غير متزوجين & \\
\hline
\end{tabular}




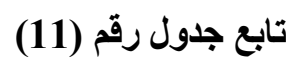

دلالة الفروق بين العاملين في التمريض لمقياس الأفكار اللاعقلانية طبقا لمتفيري الجنس والحالة الاجتماعية:

\begin{tabular}{|c|c|c|c|c|c|c|}
\hline الدلاكة & قيمة(ت) & الانحراف & المتوسط & العدد & المجموعة & الأفُكار \\
\hline \multirow[t]{2}{*}{ دالة } & \multirow[t]{2}{*}{$* 5,68$} & 1,07 & 76,2 & 72 & الممرضين & \multirow[t]{4}{*}{ الرسمية والجدية } \\
\hline & & 1,23 & 63,6 & 53 & الممرضـات & \\
\hline \multirow[t]{2}{*}{ دالة } & \multirow[t]{2}{*}{$* 6,95$} & 1,15 & 61,5 & 71 & متزوجين & \\
\hline & & 1,09 & 70,7 & 54 & غير متزوجين & \\
\hline \multirow[t]{2}{*}{ دالة } & \multirow[t]{2}{*}{$* 5,91$} & 1,01 & 70,1 & 72 & الممرضين & \multirow[t]{4}{*}{ تمييز الرجل } \\
\hline & & 1,10 & 57,3 & 53 & الممرضات & \\
\hline \multirow[t]{2}{*}{ دالة } & \multirow[t]{2}{*}{$* 6,14$} & 1,14 & 54,8 & 71 & منزوجين & \\
\hline & & 1,05 & 76,3 & 54 & غير متزوجين & \\
\hline \multirow[t]{2}{*}{ دالة } & \multirow[t]{2}{*}{$* 5,83$} & 1,04 & 68,6 & 72 & الممرضين & \multirow{4}{*}{ الارجة الكلية } \\
\hline & & 1,22 & 57,9 & 53 & الممرضات & \\
\hline \multirow[t]{2}{*}{ دالة } & \multirow[t]{2}{*}{$* 6,95$} & 1,19 & 56,4 & 71 & منزوجين & \\
\hline & & 1,06 & 73,7 & 54 & غير متزوجين & \\
\hline
\end{tabular}

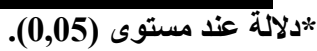

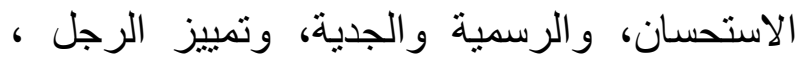

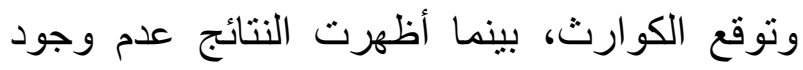

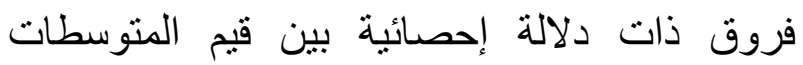
الحسابية لدرجات استجابات الممرضين و الممرضات

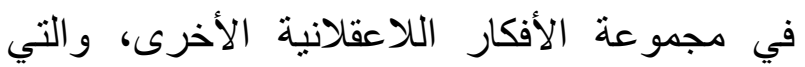
تشمل: الكمال الثخصي، ولو الآخرين ، و و عدم التسامح تجاه الاحباطات، و تضخيم، ودئ دور الظروف

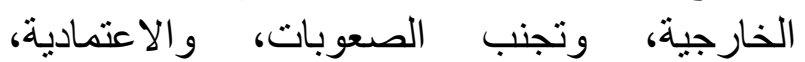
و الاحساس بالعجز تجاه الماضي.

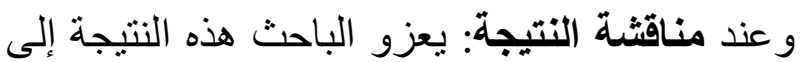

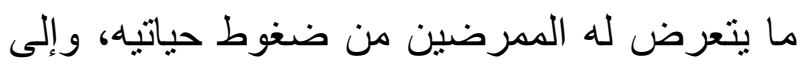
نظرة دونية من قبل المجتمع المحلي في القويعية لمهنة التمريض، ومحافظة القويعية تضم أسر من البادية

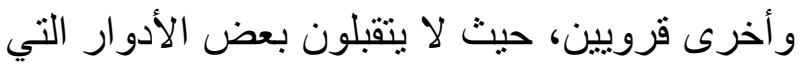

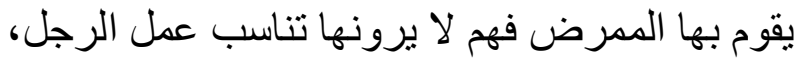

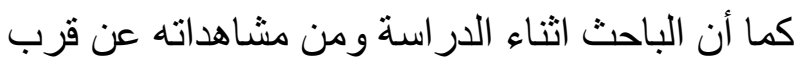

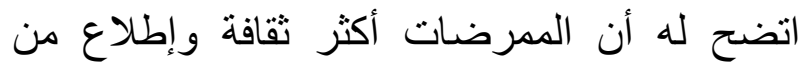
الممرضين وبالتالي يتعاملن مع الأمور بمنطقية أكثر

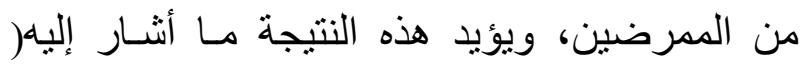

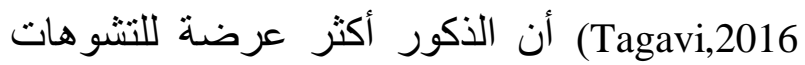

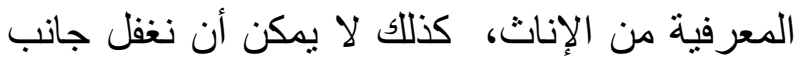

وتوضح نتائج الجدول أعلاه مـا يلي:

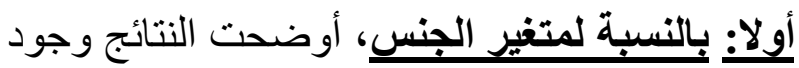
فروق ذات دلالة إحصائية عند مستوى الدلالة (0,05) بين الممرضين و الممرضات في مستثفى ومر اكز الرعاية الأولية بمحافظة القويعية في الدرجة الكلية لمقياس الأفكار اللاعقلانية ومجمو عة الأفكار كالتالي:

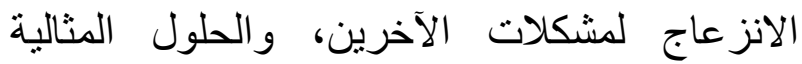
الكاملة، وطلب الاستحسان، و والرسمية و الجدية،

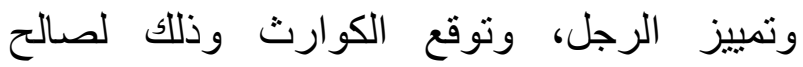
الممرضين، ويتضح ذلك من الفرق الواضح في قيم

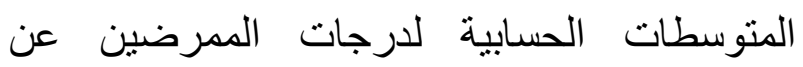
الممرضات للارجة الكلية لمقياس الأفكار اللاعقلانية، وكذللك لمجموعة الأفكار الستة المشار إلبها، و على الئ سبيل الذكر بلغت قيمة المتوسط الحسابي لاستجابات

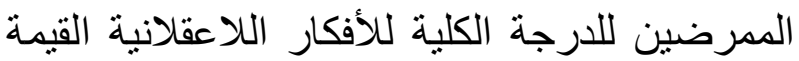
(68,6) مقابل (57,9) للمتوسط الحسابي لاستجابات

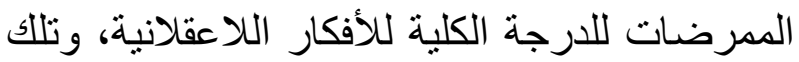
النتيجة مؤداها أن الممرضات أكثر عقلانية من

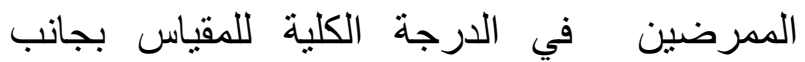

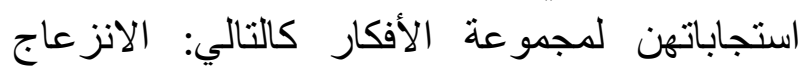
لمشكلات الآخرين، والحلول المثالية الكاملة، وطلب الب البان 
استجابات المتزوجين و غير المتزوجين في مجموعة الأفكار اللاعقلانية الأخرى والتي التيني تشمل : الكمال

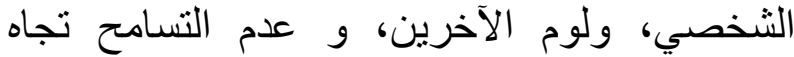

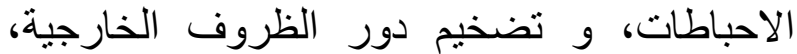

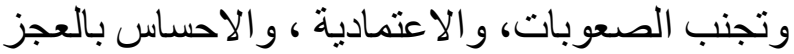

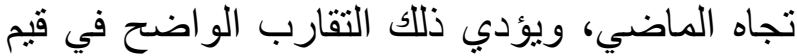
المتوسطات الحسابية لدرجات استجابات المتزوجين

و غير المتزوجين نحو هذه الأفكار اللاعقلانية.

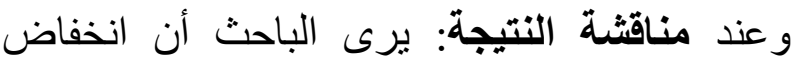

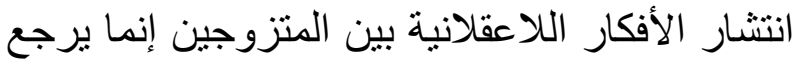

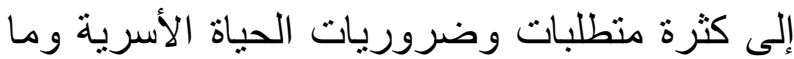
تحتاجه طبيعة هذه الحياة من تعقل ومنطقية لإدارة

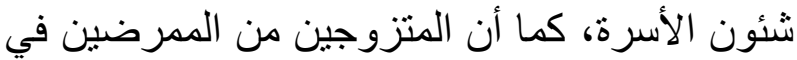

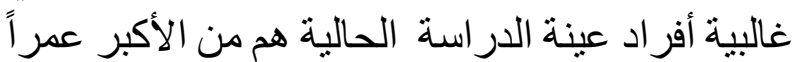

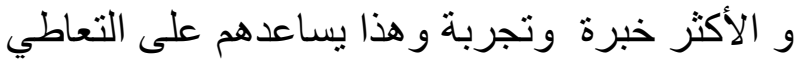
مع أمور الحياة بمنطقية وعقلانية، وتتفق هذه ونداعن النتيجة

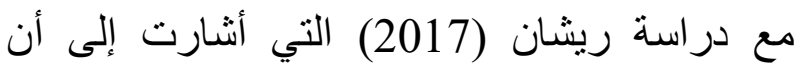
المتزوجين أكثر عقلانية من الغير متزوجين، ولكنها تختلف مع نتيجة در اسة تاغافي (Tagavi,2016) التي أشتارت انه لا توجد فروق دراته في انتشار الأفكار اللاعقلانية تبعاً لمتغير الحالة الاجتماعية، وقد أنثار (Shaffer,2006)

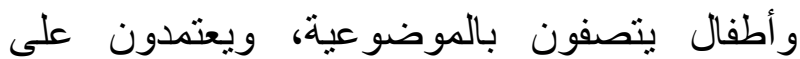
توقعات منطقية. التوصيات والمقترحات: - عمل بر امج علاجيه و إرشادية للممرضين من غير المتزوجين لاحض الأفكار اللاعقلانية، و المعتقدات الغير منطقية. ـ ـ أن توفير بيئة عمل جاذبة، وحوافز مادية جيدة، و التدريب على رأس العمل، عوامل مساعدة على وحلى خفض الضغوط النفسية لدى العاملين في مهنة

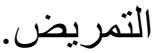

التنشئة الاجتماعية التي جعلت الممرضين يستجييون للمو اقف الضاغطة بطريقة غير عقلانية، وتتفق هذه النتيجة مع در اسات هديوه (2018)؛ ودر اسة ريشان (2017)؛ ودر اسة تاغافي (Tagavi,2016)؛ ودر اسة (2018) مجلي (2011)، وتختلف هذه النتيجة مع نتيجة در اسة عصام زيدان وآخرون (2017) والتي توصلت إلى دئ عدم وجود فروق ذات دلالة إحصائية بين الذكور والإناث على الدرجة الكلية لمقياس الأفكار اللاعقلانية.

ثانيا: بالنسبة لمتغير الحالة الاجتماعية ، أوضحت

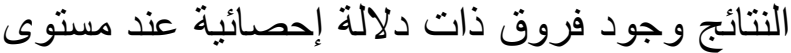
الدلالة (05،05) بين المتزوجين و غير المتزوجين من العاملين بمهنة التمريض في مستشفى ومر اكز الر عاية الرئية

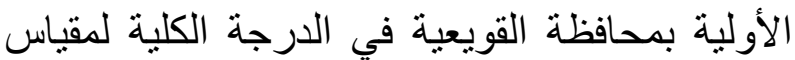
الأفكار اللاعقلانية، ومجموعة الأفكار كالتالية التئي:

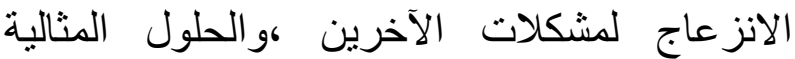
الكاملة، وطلب الاستحسان، و والرسمية و الجدية، وتمييز الرجل، وتوقع الكوارث وذللك لصالح غير الصنا المتزوجين، ويتضح ذلك من الفرق الواضح في في الكيم المتوسطات الحسابية لدرجات المتزوجين عن غير المنزوجين للارجة الكلية لمقياس الأفكار اللاعقلانية،

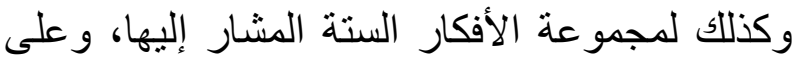
سبيل الذكر بلغت قيمة المنتسط الحسابي لاستجابات غير المتزوجين للارجة الكلية للأفكار اللاعقلانية لإنية القيمة (73،7) مقابل (56،4) للمتوسط الحسابي لاستجابات المتزوجين للارجة الكلية للأفكار اللاعقلانية، وتللك النتيجة مؤداها أن المتزوجين أكثر

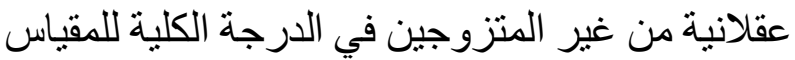

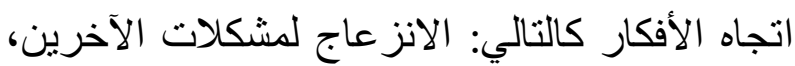

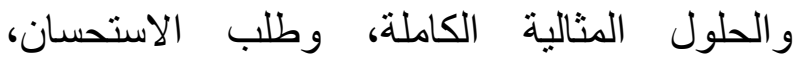
و الرسمية والجدية، وتمييز الرجل ، وتوقع الكوارث،

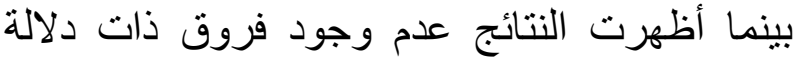
إحصائية بين قيم المتوسطات الحسابية لدرجات 
- تقديم برامج توعوية لأسر العاملات في مهنة

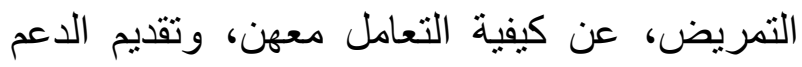

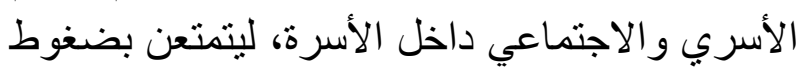
نفسية أقل. - بناء برنامج علاجي وفق نظرية اليس Ellis لتعديل

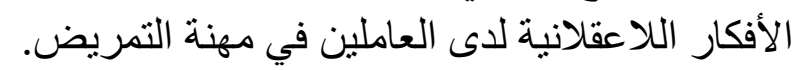

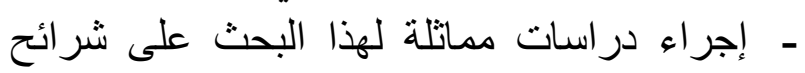
اجتماعية مختلفة والتعرف على أثر الضغوط التراء النفسية على متغير ات أخرى. 
- الصباح، سهير سليمان و الحموز، عايد محمد الصائ

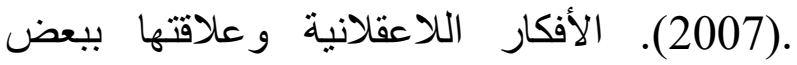
المتغيرات لدى طلبة جامعات الضفة الغربية في فلسطين. مجلة اتحاد الجامعات العربية،79(49)،

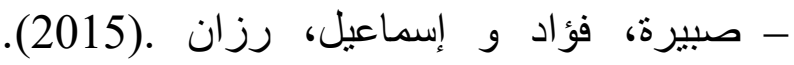

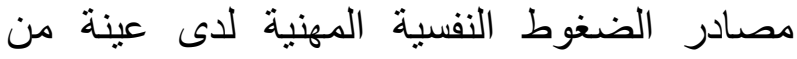
الممرضين و الممرضات " در اسة ميدانية في مسنشفى المئه الأسد الجامعي". مجلة جامعة تشربن للبحوث والدر/سات العلمية، 37(2)، 160-147.

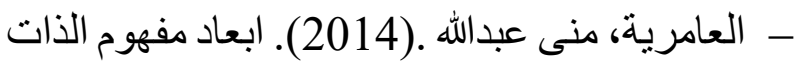

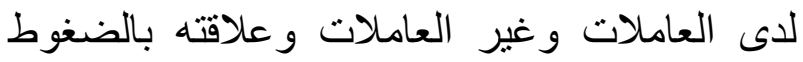
النفسية والتوافق الأسري بمحافظة الداخلية. رسالة

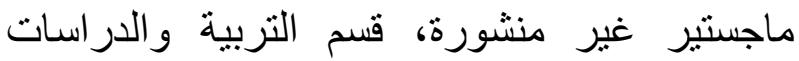
الإنسانية، جامعة نزوى.

- عبدالرحمن، محمود السيد و عبدالله، معتز سيد

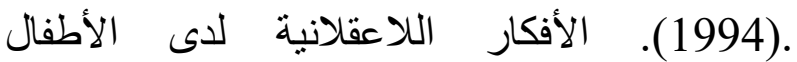
و المراهقين و علاقتها بكل من حالة وسمة القلق

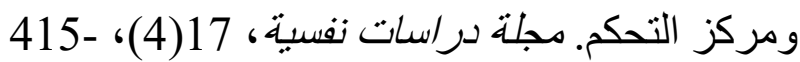

- عبدالرحيم، عائشة علي. (2011). الضغوط النفسية لاى الطلاب الجامعيين و أساليب تعاملهم معا في ضوء المستوى الاجتماعي و الاقتصادي لأسر هم.

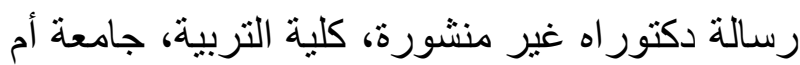
درمان الإسلامية.

- عبده، أشرف علي. (2000). الإرشاد النفسي بين النظرية والتطبيق، ط1: القاهرة. مكتبة الانجلو المصرية.

- عربيات، احمد عبدالحليم .(2005). فعالية برنامج ارشادي يستند إلى استراتيجية حل المشكلات في تخفيف الضغوط النفسية لدى طلاب المرحلة الثانوية. مجلة جامعة ام القرى للعلوم التربوية والاجتماعية

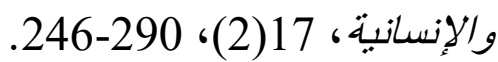

\section{المراجع}

المراجع العربية:

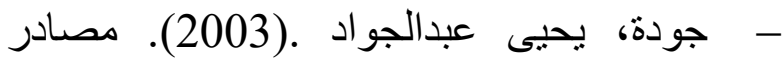
ضغوط العمل لدى الممرضين و الممرضات العاملين في مستشفيات محافظات شمال الضفة الغربية. رسالة ماجستير غير منشورة، جامعة النجاح الوطنية، فلسطين. - - الخواجا، عبدالفتاح محمد .) العلاج النفسي المعاصر-تطبيقات للنظريات. ط1. عمان: دار المستقبل للنشر و التوزيع.

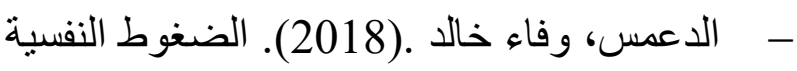

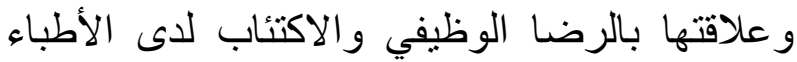
و الممرضين. مجلة الجامعة الإسلامبية للدراسات التربوية و النفسبة ، 26(5)، 749-712. - - الريحاني، سليمان .(1987). الأفكار اللاعقلانية عند الأردنيون والأمريكيون. مجلة دراسات الجامعة الحانة الأردنبية، 14(5)، 73- 124.

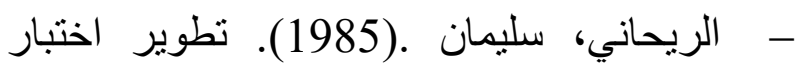

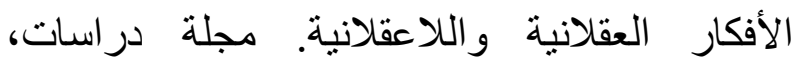
$177-140$ ، 1412 - - ريشان، حامد قاسم .(2017). الضغوط النفسية و علاقتها بالأفكار اللاعقلانية لدى موظفي جامعة البصرة. مجلة أداب ذي قار ، 22(3)، 388-348. - - الزملي، ايمن مصطفى و العيدان، بيان إبر اهيم

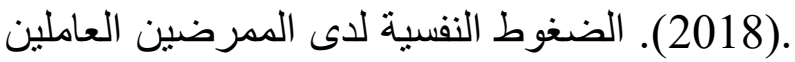
في العناية المركزة في المستشفيات الحكومية و علاقتها بالرضا الوظيفي. مجلة جامعة الاسراء للعلوم الإنسانية ، 5(7)، بالنافيا

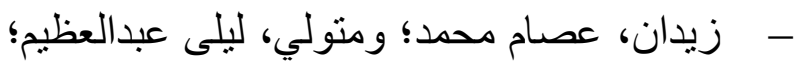
و الباز، معتز محمد .(2017). العلاقة بين الأفكار

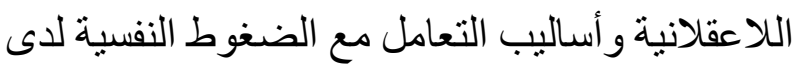
عينة من المر اهقين المكفوفين. مجلة التربية النوعية ، .170-145، (4)47 
- هديوة، مريم علي .(2018). الأفكار اللاعقلانية

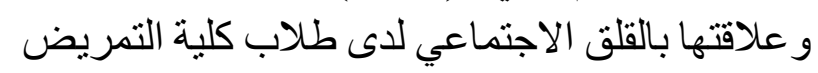
في جامعة تشرين. مجلة تشربن للبحوث و الدراسات العلمبة ، 40(4)، 248-233.

\section{المراجع الأجنبية:}

- Alfano, A. (2006). Cognitive among children and adolescents correlates of Social phobia, Journal of abnormal childpsychology, 7 (43), 189- 201.

- Boyd, J. (2005).Conflict and Role Ambiguity as Predictors of Hospice Nurses and Social Workers. Unpubished ph.D.Disertation, University of Florida.

- Dugan, M. (2016). Stressful Nurses: The effect of patient outcomes Journal Nurse Care Quality, 10(3), 46-88.

- Ellis, A. (1990). Rational and Irrational in Counselling British Psychological Association. Journal of Rational Emotive and Cognitive Behavior Therapy. 6. (4), 221-233.

- Fiaban, E. (2012), Occupational stress and jop satisfaction of Healthcare staff in rehabilitation units . La Medicina Del Lavoro Journals, 103(6): 92- 482.

- Gilany, A. (2008). Stress Among Medical And Law Students In Mansoura. Middle East Journal Of Family Medicine, 6 (9), 31-36.

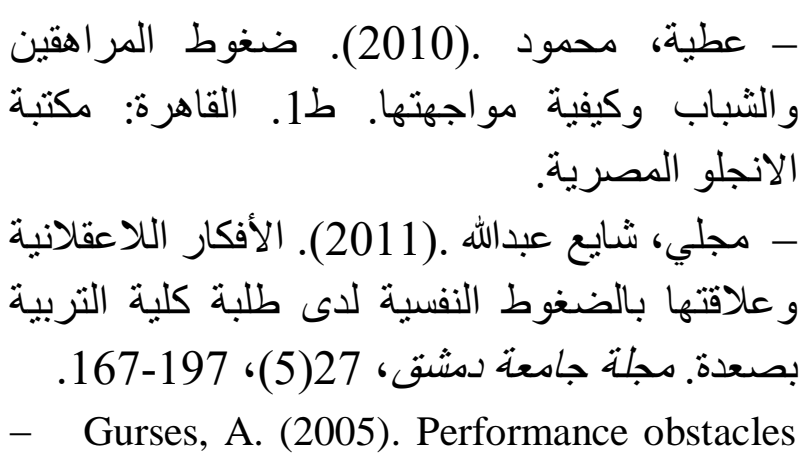
and facilitators, workload, quality of working life, and quality and safety of care among intensivecare nurses, Ph.D., The University of Wisconsin - Madison.

- Huey, M. (2004). Nurses Self-assessment of their nursing competencies, Job demands, and Job performance in the Taiwan Hospital System ,international Journal of Nursing Studies,.41(5), 487-496.

- John, S. (2007). Subjective Stress, Job Satisfaction, and Job performance of Hospital nurses, Journal nursing \& Health, 10 (4), 253261.

- Lazarus, R. (2006). Stress and Emotion A New Synthesis. Springer Publishing Company, New York.

- Lazarus, R., \& Folkman, S. (2003). Stress appraisal and coping. New York: Springer publishing comp.

- Marie, C. P. (2007). Burnout Syndrome in Critical Care Nursing Staff,American Journal of Respiratory and Critical Care Medicine 17(3). 45-76. 
- Marrina, T. (2010). Guid To Nursing Management, TORONTO:MoSby.

- Nam, S. (2016). Job Stress and Job Satisfaction among Health-Care Workers of Endoscopy Units in Korea. clinical endoscopy journal, 49(3): 266-272.

- Palmer, S., \& Dryden. W. (2002): The Rational Emotive Behavior Therapist, Journal of the Association for Rational Emotive Behavior Therapy , 10 (1), 123-170.

- Patrick, A. (2013). Sources of stress and Psychological well-being in high dependency nursing. Journal of Advanced Nursing, 19(4), 112-133.

- Poursadeghiyan, M. (2016). Relationship Between Job Stress and Anxiety, Depression and Job Satisfaction in Nurses in Iran. The Social Sciences Journals , 11(9): 2349-2355.

- Scott, S. J. (2004). Cognitive Behavior Therapy: Notes on Theory and Application with Children, G. P, Opinion Papers (120), New Jersy: Gerenal Learning Press.
- Shaffer, M. (2006). Life after stress. New York: Plenum Press.

- Sullivan, J. (2011).Occupational stress in psychiatric nursing ,Journal of Advanced Nursing ,18 (1) ,591- 601 .

- Taghavi, M. (2016).Irrational beliefs in major depression and generalized anxiety disorders in an Iranian sample. The Social Sciences Journals , 17(5): 234-255.

- Taylor, S. (2000). Health psychology, Third Edition, New York: McGraw-Hill International Editions.

- Vandevala, T. (2017). Psychological rumination and recovery from work in intensive care professionals: associations with stress, burnout, depression and health. Journal of Intensive Care, 5(16): 123-146.

- Wu, S. (2008) . Relationship between job burnout and occupational stress among doctors in China, Stress and Health, 24, (2), 143- 178. 


\title{
Psychological stress in its relationship with irrational thoughts in nursing profession workers inhospitals and primary care centers of Al-Quwaiyah governorate
}

\author{
ABDULLAH BIN SALEH AL-QAHTANI \\ Associate Professor of Psychology, Shaqra University
}

\begin{abstract}
. the current study aimed to identify psychological stress in its relationship with irrational thoughts in the nursing profession workers in hospitals and primary care centers in a Al-Quwaiyah governorate. The researcher used the descriptive, associative approach between the study variables, and the study was applied to a sample of (72) male nurses and (53) female nurses. The researcher used psychological stress scale in nursing profession workers (by the researcher), Suleiman Al-Rehany scale (1985) that is used for irrational thoughts. The study results indicated that nursing profession workers suffer from psychological stress (39.2\%), and that prevalence of irrational thoughts in the nursing profession workers at a rate of $(31.2 \%)$. The results also revealed that there is a relationship between psychological stress and irrational thoughts in the study sample. The results also showed that there are statistically significant differences in psychological stress level between male and female nurses favoring female nurses, and also between married and unmarried nurses favoring married ones, the results also indicated that there are statistically significant
\end{abstract}


differences in prevalence of irrational thoughts in male nurses and female nurses favoring male nurses and between married and unmarried nurses favoring unmarried ones. 